\title{
LONG-TERM EFFECTS OF EQUAL SHARING: EVIDENCE FROM INHERITANCE RULES FOR LAND
}

\author{
Charlotte Bartels \\ Simon Jäger \\ Natalie Obergruber \\ Working Paper 28230 \\ http://www.nber.org/papers/w28230 \\ NATIONAL BUREAU OF ECONOMIC RESEARCH \\ 1050 Massachusetts Avenue \\ Cambridge, MA 02138 \\ December 2020
}

The authors would like to thank Adrian Adermon, Sascha O. Becker, Timm Bönke, Davide Cantoni, Francesco Cinnirella, Giacomo Corneo, Johannes Eigner, Oliver Falck, Leander Heldring, Erik Hornung, Thomas Piketty, Cory Smith, Uwe Sunde, and Ludger Wößmann for helpful comments. Furthermore, we thank participants of the European Macro History Online Seminar 2020, Verein für Socialpolitik and IIPF 2020. The views expressed herein are those of the authors and do not necessarily reflect the views of the National Bureau of Economic Research.

NBER working papers are circulated for discussion and comment purposes. They have not been peer-reviewed or been subject to the review by the NBER Board of Directors that accompanies official NBER publications.

(C) 2020 by Charlotte Bartels, Simon Jäger, and Natalie Obergruber. All rights reserved. Short sections of text, not to exceed two paragraphs, may be quoted without explicit permission provided that full credit, including $\odot$ notice, is given to the source. 
Long-Term Effects of Equal Sharing: Evidence from Inheritance Rules for Land

Charlotte Bartels, Simon Jäger, and Natalie Obergruber

NBER Working Paper No. 28230

December 2020

JEL No. E02,H24,J24,J43,N13,N14,N23,N24,N33,N34,N53,N54,N93,N94,O3,P42,R52

\begin{abstract}
$\underline{\text { ABSTRACT }}$ industrial economy and, in the long-run, more entrepreneurship.

Charlotte Bartels

DIW Berlin

Mohrenstr. 58

10117 Berlin

Germany

and IZA

cbartels@diw.de

Simon Jäger

Department of Economics, E52-454

MIT

77 Massachusetts Avenue

Cambridge, MA 02139

and IZA

and also NBER

sjaeger@mit.edu

Natalie Obergruber

CESifo

Poschingerstraße 5

München 81679

Germany

and IZA

nobergruber@gmail.com
\end{abstract}

What are the long-term economic effects of a more equal distribution of wealth? We exploit variation in historical inheritance rules for land traversing political, linguistic, geological, and religious borders in Germany. In some German areas, inherited land was to be shared or divided equally among children, while in others land was ruled to be indivisible. Using a geographic regression discontinuity design, we show that equal division of land led to a more equal distribution of land; other potential drivers of growth are smooth at the boundary and equal division areas were not historically more developed. Today, equal division areas feature higher average incomes and a right-shifted skill, income, and wealth distribution. Higher top incomes and top wealth in equal division areas coincide with higher education, and higher labor productivity. We show evidence consistent with the more even distribution of land leading to more innovative industrial by-employment during Germany's transition from an agrarian to an 


\section{Introduction}

One of the oldest debates in economics concerns the effect of inequality on growth and development (see, e.g. Kuznets 1955). How would growth prospects change if income or wealth were counterfactually distributed more evenly? The answer to this question has become particularly relevant in recent decades due to rising levels of income and wealth inequality (Piketty \& Saez 2014, Alvaredo, Atkinson, Piketty \& Saez 2013). Yet, the debate has remained active due to the scarcity of suitable data and credible research designs that allow for an estimation of causally interpretable effects, as variations in inequality likely correlate with drivers of growth (Banerjee \& Duflo 2003).

We contribute to the resolution of this debate by leveraging sharp geographic variation in institutions that govern how resources are passed from parents to children. Historical inheritance rules for agricultural land varied sharply within Germany and prescribed either equal or unequal division of land among a decedent's children, also referred to as partible or impartible inheritance, respectively. In unequal division areas, agricultural property was considered indivisible and had to be passed on to a single heir. In contrast, agricultural land had to be divided equally among all children in equal division areas. Broadly speaking, equal division of agricultural land was prevalent in parts of Southern and Western Germany and the boundary between the two inheritance rule regimes traverses political, linguistic, geological, and religious borders. Figure 1 shows an example of this geographic variation, depicting a fine-grained map of inheritance regimes in the South-Western state of Württemberg in 1905-10.

We analyze historical and long-run effects of these inheritance rules on economic outcomes and their distribution in a geographic regression discontinuity (RD) design. We digitized and geocoded data from fine-grained historical surveys on the local prevalence of inheritance rules

across $19^{\text {th }}$ century Germany (see e.g. Sering 1897). We show that predictors of long-term development and also of a particular inheritance rule regime are smooth at the boundary, thereby suggesting that the variation in inheritance rules that we analyze is idiosyncratic and not systematically related to other drivers of growth. At a fine geographic level, the data therefore show a robust effect of lower levels of landholding inequality in the $19^{\text {th }}$ century caused by the equal division inheritance regime - on long-term economic outcomes and allow us to rule out a variety of potential confounders. 
Throughout the $19^{\text {th }}$ century, ownership of land - the key store of wealth in an agricultural society - was more evenly distributed in equal division areas with a reduction in the landholding Gini coefficient by about a third of a standard deviation. Our evidence shows that inheritance rules indeed affected the inequality of landed wealth during the industrialization period. This finding is non-trivial: for example, a Coasean argument would suggest that inter vivos land transactions may lead to concentrated land ownership in equal division areas, e.g., if transaction costs were low and concentrated ownership were optimal.

The core result of our paper is that equal division of land has generated persistent effects until today: modern income and GDP levels are 6 to 14 percent higher in equal division areas. The more even distribution of land in the $19^{\text {th }}$ century triggered a greater variety of activities during industrialization resulting in a more dispersed distribution today. Higher top incomes, higher top income shares and higher top wealth coincide with higher education, and higher labor productivity in equal division areas today.

Why might a more even wealth distribution spur long-term growth? Previous work has argued that the small and fragmented peasant holdings in equal division areas created both the incentive and the opportunity for extensive engagement in industrial by-employments as compensatory strategies which in turn provided the breeding ground for Germany's Mittelstand today (Herrigel 2000). ${ }^{1}$ An influential body of literature hypothesizes that the distribution of wealth affects long-term growth through its effect on investment decisions and the occupational choice of individuals (see, e.g., Galor \& Zeira 1993, Banerjee \& Newman 1993, Ghatak \& NienHuei Jiang 2002, Galor \& Moav 2004). In such models, individuals have the choice between, e.g., subsistence farming and becoming a skilled worker or entrepreneur. Compared to a situation in which a large part of the population has essentially no wealth, a more even distribution of wealth can alleviate credit constraints in parts of the population or provide a buffer to absorb the potential risks of innovating, investing in human capital, or becoming an entrepreneur, all of which have favorable consequences for growth.

Historical accounts provide evidence consistent with inheritance rules affecting long-term growth through an occupational choice mechanisms. For example, the Finance Minister in the Kingdom of Württemberg argued that Württemberg's economic strength at the time, in 1823,

\footnotetext{
${ }^{1}$ Mittelstand refers to the segment of Germany's economic landscape shaped by small- and medium-sized firms.
} 
was "the unconditionally permissible division of landed property. On property of paltry size, the industriousness, thrift and ingenuity of the owner blossoms. He nourishes himself in the character of a businessman [Gewerbsmann], indeed, he becomes [...] a business man. [...] No matter where one looks, one finds everywhere industrious artisans, highly skilled manufacturers and thoughtful merchants. That is the character of industry in this land. [... J Supported by their small farms they are at least able to salvage a meager existence until luck or genius brings to them better times" (see Herrigel 2000, p.56). The assessment is consistent with the hypothesis that occupational choice and entrepreneurship could be mechanisms through which a more even distribution of landed wealth contributed to long-term growth.

We investigate the hypothesized mechanism empirically drawing on our RD design and find that occupational choice indeed differed between equal and unequal division areas during Germany's industrialization as predicted by the models. Specifically, we find that higher shares of the population in equal division areas-with a more even land distribution-worked in manufacturing as well as in trade and services. The additional employment in manufacturing is fully accounted for by employment in particularly innovative sectors with high patenting activity (defined following Streb, Baten \& Yin 2006), which command a 36 percent higher employment share in equal division areas. We also find that self-employment out of agriculture is slightly higher in equal division areas as well as the density of middle schools which addressed students who want to become an apprentice. Finally, patenting activity itself was also higher in equal division areas. Overall, the data suggest that a more even distribution of wealth enabled workers to take up new opportunities during the transition from an agricultural to an industrial economy, and ultimately, become entrepreneurs. We find no evidence of more advantageous starting conditions for equal division areas before the Industrial Revolution with respect to agricultural productivity, general education, urban population or population density.

Our findings support several models in which landholding inequality may inhibit economic growth by restricting occupational choice. Galor, Moav \& Vollrath (2009) formalize in a theoretical model that a more equal land distribution supports the rise of a new entrepreneurial elite during industrialization. The entrepreneurial elite then supports education of the former unskilled labor force. Data on education spending during the high-school movement in the US delivers evidence for that model. Similarly, Cinnirella \& Hornung (2016) find for Prussia a negative cross-sectional relationship between large landholdings and primary school enrollment 
rates throughout the $19^{\text {th }}$ century. With our findings that equal division counties are characterized by higher innovative activity and more self-employed people out of agriculture, we deliver evidence that a more equal land distribution fosters the rise of a new entrepreneurial elite and, perhaps, economic growth.

More broadly, our study builds on several additional strands of the literature. We add causal evidence to the literature on the long-term effects of historical conditions on the economic development (see, e.g., La Porta, Lopez-de Silanes, Shleifer \& Vishny 1998, Acemoglu, Johnson \& Robinson 2001, Glaeser, La Porta, Lopez-de Silanes \& Shleifer 2004, Nunn 2009, Alesina, Giuliano \& Nunn 2013) and show that an inclusive institution, leading to a more equal distribution of landed wealth, fostered long-term growth. More directly, we build on the literature studying the economic and political consequences of landholding inequality (see, e.g., Gerschenkron 1966, Banerjee, Iyer \& Somanathan 2005, Banerjee \& Iyer 2005, Acemoglu, Bautista, Querubín \& Robinson 2007, Ziblatt 2008, Becker, Cinnirella \& Woessmann 2010, Bleakley \& Ferrie 2016, Smith 2019). In addition, our study builds on previous research on industrialization in Germany (see, e.g., Gerschenkron 1989, Tilly 1969, Eichengreen \& Ritschl 2009, Herrigel 2000). Furthermore, our findings are consistent with Doepke \& Zilibotti (2008) who argue that occupational choice plays a crucial role during the Industrial Revolution and posit a concomitant downfall of the landed elite. Related to our work, Duranton, Rodríguez-Pose \& Sandall (2009) correlate the regional prevalence of particular medieval family types with long-run outcomes across European regions. Contrary to our findings, they observe lower GDP levels, higher levels of manufacturing, and lower levels of service sector employment in what we would classify as equal division areas. These differences in the results might arise from differences in methodology as their analysis relies on a broader, cross-regional comparison. Habakkuk (1955) analyzes the role of family structures focusing primarily on population growth. He hypothesizes that single-heir systems slow population growth whereas equal division rules foster it. With regard to mobility, Habakkuk (1955) argues that unequal division areas faced more out-migration as non-inheriting children had fewer ties to the parental home. Analyzing micro-data from $19^{t h}$ century Hesse-Cassel, Wegge (1998) finds some support for this hypothesis. In addition, our study is most directly related to work by Rink \& Hilbig (2019) who find a long-term association between equal division in Germany and more political equality today, e.g., more women 
in political councils and fewer aristocrats in the social elite. Finally, our study speaks to the historical origins of entrepreneurial activity (Glaeser \& Kerr 2009, Fritsch \& Wyrwich 2014).

Our paper proceeds as follows: Section 2 discusses the history and the hypothesized origins of agricultural inheritance rules in Germany. Section 3 gives an overview of the different data sets we use. We present and discuss our empirical strategy in Section 4. Section 5 shows the estimated effects of Equal Division and historical and modern inequality measures and on modern measures of economic well-being. Further, we discuss correlations between equal division and potential confounders. Section 6 provides evidence for mechanisms through which equal division might have affected modern outcomes. Section 7 concludes.

\section{Historical Background of Inheritance Rules}

Historically, two main rules of inheritance for farms and agricultural land existed in Germany, prescribing equal division ('Realteilung') and unequal division of land ('Anerbenrecht') (Rösener 2012). ${ }^{2}$ Under unequal division inheritance, agricultural property is considered indivisible and has to be passed on to a single heir. The most common unequal division rule prescribed "primogeniture", i.e. making the oldest son the designated heir. Historically, daughters and lastborns did not have a claim to the parental land and received little or no compensation in most unequal division areas. As a consequence, the non-inheriting children typically became landless and worked as farmhands on the inheriting brother's farm (Cole \& Wolf 1995) or in factories (Becker 1998), unless they married into a landed family. Under equal division inheritance, land holding is divided equally among all children including daughters.

Eliminating equal division had been a recurring topic in the political debate since the $19^{\text {th }}$ century (Rouette 2003, Eheberg 1883). Again and again, equal division was argued to represent a threat to the productivity of agriculture and the existence of farmers. The Nazis implemented such a reform through the 'Reichserbhofgesetz' (State Hereditary Farm Law) of 1933 introducing unequal division all over Germany (Rouette 2003). However, Röhm (1957) and Röhm (1961) later finds evidence that equal division rules persisted regionally until the

\footnotetext{
${ }^{2}$ Variations in inheritance rules are also present in other parts of Europe. In England, for example, nonpartible inheritance is traditionally applied (Alston \& Schapiro 1984) while in France (Crouch 2005) as well as the Netherlands (Alston \& Schapiro 1984) people divided farms equally. Spain applies partible inheritance in the South (Andalusia) and non-partible inheritance in the other parts (Tur-Prats 2018).
} 
1950s. Even today, inheritance of farms is locally regulated by the states. ${ }^{3}$ The state-specific rules still suspend equal division of the inheritance among a community of heirs as prescribed by the German Civil Law Code (BGB §§1922). Bavaria, Saarland, Thuringia, Saxony, SaxonyAnhalt, Mecklenburg-Vorpommern, Brandenburg, and Berlin follow BGB §2049 and §2312 (Landgüterrecht) which in general prescribes equal division but regulates that farms are assessed at a lower value than other property. The aim remains to secure productivity of agriculture.

In order to prevent the infinite parcellation of arable land below subsistence levels, farmers in equal division areas undertook different measures. First, parental property was sold to the child to whom ownership and control was passed on exclusively. The price could be paid either to the parents or to the other siblings as a one-off payment or as a regular rent. Second, land was bought and sold, primarily within family networks, with the aim of stabilizing farm sizes in the long-run. The land market has developed earlier and has been more dynamic in equal division areas since the $18^{\text {th }}$ century. In this context, intermarriage started to play an increasing role (Rouette 2003). But still, we find significantly more small farms in equal division areas than in unequal division areas, suggesting that the consequences of inheritance rules for land allocation were not fully undone by other mechanisms (see Section 5.1).

Since we use geographic variation in the historical prevalence of inheritance rules, the question of which factors lead to the adoption of a particular inheritance rule in a locality arises naturally. This question remains debated among historians, who concur that the rules had been in place since at least the Middle Ages: Two of the first written codices, the Lex Salica of 507 AD and the Sachsenspiegel of 1220 AD, regulated agricultural inheritance. The Lex Salica prescribed equal division among male offspring in Frankish lands (South-Western Germany) (Behrend 1897), whereas the Sachsenspiegel prescribed a single heir in parts of the North-East (Blanckmeister 1913).

A hypothesis dating back to at least Weber (1924) is that unequal division was established where local feudal lords or the state had the power and incentives to prohibit the division of land as it was thought that larger land plots could be taxed more easily (Rösener 2012). Other scholars have suggested that features of the terrain or the soil were conducive to the

\footnotetext{
${ }^{3}$ Hamburg, North Rhine-Westphalia, Lower Saxony, and Schleswig-Holstein introduced unequal division inheritance by the the Höfeordnung (HöfeO from 26 July 1976, BGBl. 1, S. 1933). Baden-Württemberg applies the Badisches Hofgütergesetz and Württembergisches Anerbengesetz. Hesse follows the Hessische Landgüterordnung, Rhineland-Palatinate the Rheinland-Pfälzische Höfeordnung, and Bremen the Bremisches Höfegesetz.
} 
adoption of one inheritance rule over the other (Schröder 1979). Following Boserup (1965) and Fastenmayer (2009) soil quality in combination with crops that support plough use would give an advantage to unequal division rules. Finally, Chu (1991) argued that impartible inheritance, in the form of primogeniture, may arise as family's optimal policy to the reduce the lineal extinction probability in a dynastic model.

For our application, we illustrate the fine-grained and idiosyncratic nature of the variation in inheritance rules based on a historic map from Krafft (1930) in Figure 1. The variation we exploit traverses political, linguistic, geological, and religious borders. Figure 1 illustrates variation in the prevalence of equal vs. unequal division of land from one village to the next within the same county. Moreover, the border between inheritance rules does not generally follow political boundaries. Similarly, the figure also illustrates that the inheritance rule variation also traverses a linguistic boundary between Swabian and East Franconian German dialects.

Figure 2 Panel (a) shows the overall spatial distribution of different inheritance rules in $19^{\text {th }}$ century Germany that we exploit for our analysis. ${ }^{4}$ We distinguish equal division (green) from unequal division areas (blue). Unequal division is prevalent in a majority of regions. With several exceptions, equal division is predominantly found in the southwest of Germany. The map is a combination of various sources in form of maps and texts from the late $19^{\text {th }}$ century: The first comprehensive overview of the geographic distribution of inheritance rules in Prussia was created in 1894 when the Prussian government conducted a survey among judges and county administrators to inquire into the nature and history of inheritance rules in their jurisdiction (Rouette 2003). Around the same time, similar surveys were conducted in the other kingdoms of the German Empire by Verein für Socialpolitik (1883), Grossherzogliches Ministerium des Inneren (1883), Miaskowski (1884), Fick (1895), and Krafft (1930). Several decades later, the geographers Hartke \& Westermann (1940) created an overview map that depicted the local prevalence of particular inheritance rules based on the results published by Sering (1897) and others. These surveys allow a very fine-grained categorization of inheritance rules by locality,

\footnotetext{
${ }^{4}$ We stick to the maps provided by the sources in the late $19^{t h}$ century, because local inheritance regimes were not necessarily stable over time. Rouette (2003) points to two changes in the $19^{\text {th }}$ century: The industrialized Ruhr area switched from unequal to equal division while the area around Paderborn increasingly practiced unequal division.
} 
typically at the village level..$^{5}$ In our samples the inheritance rule of each county is classified by the inheritance rule of the majority of the area of a county.

\section{Data}

This section provides a detailed description of our data sources and shows summary statistics of how equal and unequal division counties differed. The unit of observation throughout is a rural county in Germany at different points in time. ${ }^{6}$ The counties' locations are indicated by historical and modern maps of German counties provided by MPIDR [Max Planck Institute for Demographic Research] and CGG [Chair for Geodesy and Geoinformatics, University of Rostock] (2011) and the German Federal Institute for Research on Building, Urban Affairs, and Spatial Development (BBSR). We link our historical sample, consisting of 900 rural German counties in 1895 , either spatially, via official county codes, or via county names to our modern sample of 397 counties in 2014.

\subsection{Data Sources}

Our main outcome variables stem from censuses, national accounts and tax records of the Federal Statistical Office of Germany or its predecessors from the late $19^{\text {th }}$ century onward. In order to measure income inequality within and between regions in the $19^{\text {th }}$ century and today, we draw on income tax records and compute top income shares following the standards of the World Inequality Database (https: \\wid.world), i.e., we apply the Pareto interpolation method as established by Piketty (2003). Our regional income inequality series for Germany represents a new and unique contribution to international inequality data, because existing

\footnotetext{
${ }^{5}$ Where possible, we follow the original sources rather than Hartke \& Westermann (1940), whose work was published during the Nazi regime and might have been influenced by the propaganda similar to Huppertz (1939). For counties for which we could not identify the prevalent inheritance rule from the original sources we filled the gaps from the comprehensive map of Hartke \& Westermann (1940).

${ }^{6}$ Sample restrictions exclude independent cities from our analysis for several reasons. First, agriculture played a minor role in cities. Second, urbanization triggered migration into cities at a large scale and brings people with unequal division origin into areas of equal division and vice versa. Migrants' behavior influences the outcome variables of cities and we cannot distinguish if this is driven by people with equal or unequal division background.
} 
long-run inequality series measure inequality at the national level - with one regional exception for the United States. ${ }^{7}$

Historical Outcomes Historical data on farm sizes and occupations stem from the first comprehensive agricultural census for the German Empire (Kaiserliches Statisisches Amt 1912) and from two censuses on occupations and businesses (Kaiserliches Statisisches Amt 1897, Kaiserliches Statisisches Amt 1910) that we digitized. These statistics allow us to calculate average farm sizes, the share of farms across size categories, the population per county and employment shares in agriculture, manufacturing, and trade and services. Within occupations, we can identify innovative branches in manufacturing as specified in Streb et al. (2006). We enrich agricultural information by data on landholding inequality from 1895 provided by Ziblatt (2008). The distribution of height in Bavarian conscripts in the $19^{\text {th }}$ century serves as individual data on inequality (Baten 1999, Baten 2000). Patent data from Streb et al. (2006) which includes all valuable patents filed in Germany between 1877 and 1914 serves as a second measure for innovative activity. ${ }^{8}$ For the estimation of income inequality within and between counties, we use county-level income tax tabulations that provide information on income bins, including the mean income and the number of taxpayers within each bin. We digitized historical countylevel income tax tabulations from Baden, Hesse and Württemberg (see Table A3 for data sources). ${ }^{9}$ Further measures of economic development come from the census on occupations and businesses from 1925 which allows us to distinguish between employees and laborers (Fritsch \& Wyrwich 2016). ${ }^{10}$

Modern Outcomes Income, education, and industry structure on the county level are from the INKAR 2014 data set, which includes official aggregated information and is provided by the BBSR. For finer measures of income and labor productivity, we incorporate county-level national accounts and income tax records provided by the German Federal Statistical Office

\footnotetext{
${ }^{7}$ Bartels (2019) provides the WID series for Germany. The Pareto interpolation method additionally draws on population statistics for the total number of potential taxpayers and national accounts for total income as income tax statistics are restricted to the taxpaying part of the population. See Bartels (2019) for a detailed description of the method and its application to German income tax statistics 1871 to 2014.

${ }^{8}$ We thank Jochen Streb for kindly sharing his data.

${ }^{9}$ Bavaria did not publish county-level income tax information before World War I. Prussia only published tax tabulation on the more aggregate level of the Regierungsbezirk.

${ }^{10}$ We thank Michael Wyrwich for kindly sharing their data.
} 
and the Statistical Offices of the Laender. Our between-county inequality measures are the log mean income of the top $10 \%$ and the top $1 \%$ as well as the share of households in each county belonging to the bottom $40 \%$ or bottom $20 \%$ of the national income distribution. ${ }^{11}$ For the measurement of wealth, we draw on wealth data from the last collection of the German wealth tax in 1995, that lists wealth taxpayers and millionaires per 10.000 inhabitants by county.

Pre-Industrial Development For agricultural productivity before and after 1500 we use data on caloric output of land by Galor \& Özak (2016). Another measure of pre-industrial economic development is population data, which we obtain from Bairoch, Batou \& Chevre (1988) and the Statistical Office of the German Empire, which published the population of 1375 German towns and cities in 1867, 1871, and 1875 (Kaiserliches Statistisches Amt 1877). Additionally, we use data from the iPEHd on Prussia provided by Becker, Cinnirella, Hornung \& Woessmann (2014) to evaluate pre-industrial development. Tables A1 and A2 in the Appendix provide a brief overview of the variables we use from these data sets.

Control Variables We use three types of control variables: geographical variables, cultural and institutional variables, and controls for the location. The geographic control variables come from GIS raster data depicting current information on soil, climate, elevation, and navigable waterways. We rely on data from the European Soil Data Base, the free climate data from WorldClim.org and navigable waterways from Kunz (2004). The calculation of average elevation of a county is based on data from Jarvis, Reuter, Nelson \& Guevara (2006). Cultural and institutional control variables come from various sources: The share of protestants in a county stems from Konversationslexikon (1905) and the general law type stems from a map by Schröder (1870). Hanseatic involvement is inferred from a map by Helmolt (1902) as is an indicator for belonging to the Frankish territory from Shepherd (1911). We include controls for location in the form of longitude and latitude of the centroid of a county as well as an indicator for the historical state the county belongs to.

\footnotetext{
${ }^{11}$ Income tax records today exclude a third of the population which is tax exempt. Using the Socio-Economic Panel (SOEP), we estimate that the bottom $40 \%$ of potential tax households in Germany earned less than $€ 20.000$ and the bottom $20 \%$ earned less than $€ 10.000$. The SOEP allows us to rank potential tax households by their gross income according to tax law definitions so that we can identify income thresholds of the bottom $40 \%$ and bottom $20 \%$, respectively, and then estimate their population share.
} 


\subsection{Summary Statistics}

Table 1 shows summary statistics for equal and unequal division counties, which illustrate to what extent the two groups differed in their control characteristics. Panel A lists the geographic controls. In equal division areas, the average temperature and elevation are slightly higher. Unequal division areas have a significantly higher share of sand, silt, and loam in the soil, while the share of loess, which is favorable for agriculture, does not differ significantly between the two groups. Panel B shows the summary statistics of the cultural and institutional control variables. While Frankish territory and Napoleonic Code mainly appear in equal division areas and the Hanseatic League and Prussian Law in unequal division areas, the share of protestants does not differ significantly between inheritance rules. We conclude that equal and unequal division areas are not completely balanced but differ in some aspects; therefore, we include the geographic and cultural control variables later on in our analyses and use geographic regression discontinuity models with counties close to the boundary as our preferred specification.

\section{Empirical Strategy}

We apply two empirical strategies to estimate the effect of equal division on inequality and economic development. First, we estimate OLS regressions with a rich set of control variables, including flexible controls for the location of the county. Second, we view the location where unequal division changes to equal division as a boundary and discontinuous jump in inheritance rules which is determined by longitude and latitude. In this framework we apply a multidimensional, semi-parametric regression discontinuity (RD) approach similar to Dell (2010) to identify the effect of equal division. Our estimation model is:

$$
Y_{c}=\alpha+\gamma \cdot \text { Equal Division }{ }_{c}+X_{c}^{\prime} \beta+f\left(\text { Geographic Location }_{c}\right)+\phi_{s(c)}+\epsilon_{c} .
$$

The outcome $Y_{c}$ is a specific outcome measure of county c. Equal Division is an indicator variable for equal division inheritance in county $c$. The coefficient of interest $\gamma$ measures the effect of equal division and the outcome variable $Y_{c}$. The matrix $X_{c}$ contains control variables for county $c$. The term $\phi_{s(c)}$ determines the state in which county $c$ is located. Independent cities 
of one state are clustered locally. Therefore, the state dummies divide the border of inheritance rule into nine different segments. ${ }^{12}$

The polynomial $f($ Geographic Location $)$ is a linear function of longitude and latitude in the OLS specification. Our RD specification additionally includes distance to the boundary and an interaction term of treatment and distance to the border to allow the slope to vary on either side of the border. As a robustness check, we use a quadratic polynomial that controls for squared longitude, latitude, and distance to the boundary, as well as interactions between longitude and latitude, longitude and distance to border and, finally, latitude and distance to border. Our main results are qualitatively and quantitatively robust to using the quadratic polynomial instead.

We use the full sample of all rural counties in Germany in a specific year for the OLS specification. For the RD specification, we reduce the sample to counties with a centroid in a 35 $\mathrm{km}$ radius of the border as Figure 2 Panel (b) shows. We test the robustness of the RD results by varying the distance to border (see Figures 5 to 7 ). Standard errors are clustered at the district level which is one aggregation level above the county level. ${ }^{13}$ We also present HAC standard errors following Conley (1999) to account for spatial autocorrelation. Counties are weighted by the number of their inhabitants in order to allow a population-related interpretation of our results. Independent cities are excluded in our historical analysis. In our analysis of modern outcomes, independent cities with more than 100.000 inhabitants are excluded.

\subsection{Identification Assumption}

The $\mathrm{RD}$ approach relies on the identification assumption that the characteristics between the two groups - i.e. across the border - vary smoothly. In order to test this assumption, we test whether predictors of inheritance rules or of long-term development differ discontinuously at the boundary between the two regimes. We predict each relevant outcome based on a linear specification using all our control variables as potential predictors.

Figure 3 Panel (a) plots the predicted equal division against the distance of a county to the border of inheritance rule. No jump or discontinuity in the outcome variable at the boundary can

\footnotetext{
${ }^{12}$ The segments including both inheritance rules are: Prussia, Bavaria, Baden, Württemberg, Hessia, Schwarzburg Rudolstadt, Sachsen Weimar Eisenach, Sachsen Meinigen Gotha, Sachsen Coburg Gotha.

${ }^{13}$ There are 51 districts i.e. clusters in a $35 \mathrm{~km}$ radius to the inheritance rule border.
} 
be detected. Moreover, Figure 3 reveals that the relationship between controls and inheritance rule in a range of $35 \mathrm{~km}$ left and right of the border can be well approximated with a linear specification. Taken together, this evidence supports the identification assumption and suggests that, close to boundary, equal and unequal division areas did not differ discontinuously in the characteristics that determine particular inheritance rules in the cross-section.

We next check the continuity of indicators of predicted long-term development at the boundary in Figure 3 Panels (b) and (c). If counties sorted into equal division based on unobserved characteristics, which are positively correlated with income today, Figure 3 Panels (b) and (c) would reveal a positive discontinuity with respect to GDP per capita and household income per household member, respectively. The evidence does not support such a conclusion. For a measure of predicted GDP per capita, no large positive discontinuity at the boundary is discernible. For predicted household income, we find an economically small change at the boundary, with equal division areas having features that are associated with, if anything, slightly lower long-term household income levels. Taken together, the results in Figure 3 lend support to a geographic discontinuity strategy.

\section{Results}

Our analysis proceeds in two parts: First, we provide evidence on the historical effects of equal division and inequality before and throughout the Industrial Revolution. Second, we assess the long-term effects of historical inheritance rules on modern outcomes and their distribution.

\subsection{Effects of Equal Division at the Turn of the $19^{\text {th }}$ Century}

The first step of our empirical analysis is to assess if, historically, equal division of land resulted in lower inequality. We investigate landholding inequality, individual height inequality and income inequality at the turn of the $19^{\text {th }}$ century. While we find significantly more landholding and height equality in equal division areas, there are no significant differences in income inequality. 
Landholding Inequality Table 2 shows regression results for landholding inequality in 1897. Landholding Gini coefficients are significantly lower by about a third of a standard deviation (SD) in our RD specification. ${ }^{14}$ The distribution of farms sizes in equal division areas is shifted to the left. There are significantly more small farms below 5 hectares and less large farms between 5 and 20 hectares or between 20 and 100 hectares. ${ }^{15}$ This higher share of small farms in equal division is also visible in pre-industrial Prussian census data of 1816 (see Appendix Table A5). Landholding inequality and farm size effects are robust to including geographic and cultural controls (Panel B), to the restrictions of the RD approach (Panel C), to allowing to the slope to vary on either side of the inheritance regime border (Panel D) and to varying the distance to border (Figure 5).

The snapshot in 1895 does not reveal whether equal division was still performed at the end of the $19^{\text {th }}$ century. Differences might have emerged hundreds of years ago and may not have faded away by 1895. Appendix Table A6 shows that equal division was indeed still performed: a difference-in-differences analysis between 1895 and 1907 shows that within 12 years farms in equal division areas became significantly smaller and the share of small farms increased even more.

Our results on landholding inequality establish two core facts: First, until the end of the $19^{\text {th }}$ century, equal division affected the distribution of land. Second, although people could have sold their inherited land and moved to cities or abroad, this was not common practice. A Coasean argument would suggest that inter vivos land transactions should have concentrated land ownership in equal division areas if transaction costs were low and if concentrated land ownership were optimal for agricultural productivity. Yet, the evidence shows persistent differences in landholding inequality at the boundary between the two inheritance regimes, contrary to a Coasean argument.

Height Inequality To complement our analysis of landholding inequality, we also study inequality in height, a well established measure of individual well-being in terms of nourishment and health (van Zanden, Baten, d'Ercole, Rijpma, Smith \& Timmer 2014, Fogel 1986). We

\footnotetext{
${ }^{14}$ This finding is robust to including the quadratic polynomial instead, as shown in Column 2.

${ }^{15}$ The census also includes a category for farms above 100 hectares. There are no significant differences between equal and unequal division counties in the share of farms above 100 ha. It is likely that church land and feudal estates which existed in both inheritance regimes fall in that category and were not affected by inheritance rules.
} 
calculate the SD of individual height of 20-year-old conscripts in Bavarian counties in the $19^{\text {th }}$ century combined with information on their county of origin. ${ }^{16}$ We find significantly less variation in height in equal division counties (see Appendix Table A13). ${ }^{17}$ Hence, at least in the context of Bavaria for which we have height data, it appears that not only the production factor land but also inputs into physical development like food were distributed more equally in equal division counties.

Income Inequality We draw on county income tax tabulations in 1895 and 1907 to compute the top $10 \%$ and top $1 \%$ income share as a measure of income inequality. Table A7 shows that income inequality did not significantly differ between equal and unequal division areas, neither in 1895 nor in 1907. However, we find evidence for differences in the income composition. While total average incomes reveal no significant differences (columns 4 and 8 of Table A7), average business incomes were significantly higher in equal division areas (column 1 in Appendix Table A15). This already points to our suggested occupational choice mechanism, which we explore in more detail in Section 6: Farmers with small landholdings in equal division areas compensated their smaller agricultural incomes with income from industrial by-employment. As we will demonstrate in the following, the entrepreneurial activities emerging in equal division areas during the transition phase from an agricultural to industrial economy provided the ground for more dynamic economic activities in the long-run.

\subsection{Long-Term Effects of Equal Division: Modern Outcomes}

Here, we show that the equal division of land had persistent effects on income, education, and the accumulation of wealth. Higher average incomes in equal division go along with a more widespread distribution of skill, income and wealth.

\footnotetext{
${ }^{16}$ See http://www.uni-tuebingen.de/fakultaeten/wirtschafts-und-sozialwissenschaftliche-fakultaet/ faecher/wirtschaftswissenschaft/lehrstuehle/volkswirtschaftslehre/wirtschaftsgeschichte/data-hub-height.html as well as Baten (1999) and Baten (2000) for more information on the context and the data.

${ }^{17}$ To check weather Bavaria is a good case study for the effect of equal division, we estimated the same regressions as in Table 2 but only for Bavaria. Table A9 in the Appendix shows the results. As the number of observations is strongly reduced, the effects are hardly significant. The effects of the Gini coefficient are positive but become very small at the border. The percentages of farms in specific size categories are similar to our findings for whole Germany, indicating that Bavaria qualifies as an appropriate sample of the whole population.
} 
Income Today's income and GDP per capita is, on average, higher in equal division counties than in unequal division counties. Table 3 shows that inheritance rules have persistent effects on average income, which are positive, highly statistically significant, and robust across all specifications. Further, the effects are robust to using the quadratic polynomial including interactions between longitude, latitude and distance to border (see Appendix Figure A4). The results are robust to allowing the slope to vary on either side of the inheritance regime border (Panel D) and to varying the distance to border (Figure 6). The magnitudes for all income measures are around 45 percent of a SD (except for median income at about 27 percent). Equal division counties have 6-14 percent higher income and GDP levels today.

Top Incomes Top incomes are significantly higher in equal division counties, as shown in Table 4. We find that the top decile and the top percentile in equal division counties earn 914 percent more than their counterparts in unequal division counties. This implies substantial income inequality between equal and unequal division counties. Hence, we document a income gap between equal and unequal division both for average incomes (Table 3) and for top average incomes.

Top Income Shares Income concentration within equal division counties is significantly higher than in unequal division counties. This is shown by the income shares of the top decile and the top percentile in total county income. On average, 37 percent of total income accrues to the top decile, and 11 percent of total income accrues to the top percentile. In equal division areas, the top $10 \%$ income share is about 2 percentage points higher and the top $1 \%$ income share is about one percentage point higher. These magnitudes are around 30 percent and 45 percent of a SD, respectively. ${ }^{18}$

Top Wealth Drawing on data from the last collection of the German wealth tax in 1995, we find that top wealth is significantly higher in equal division counties (see the last two columns of Table 4). There are about 35 more wealth taxpayers and about seven more millionaires per 10.000 inhabitants in equal division counties, on average. The magnitudes correspond to around

\footnotetext{
${ }^{18}$ The share of low-income households is lower in equal division counties. More precisely, there are fewer households in equal division counties who belong to the bottom $40 \%(<€ 20.000)$ or bottom $20 \%(<€ 10.000)$ of the national income distribution, respectively. This suggests that higher income concentration at the top in equal division countries does not come at the expense of lower bottom incomes.
} 
60 percent of a SD. Hence, the initially more equal distribution of wealth during the transition phase from an agrarian to an industrial economy resulted in a more dispersed distribution of wealth in the long-run.

Human Capital and Productivity Results on educational outcomes, productivity and industry structure (Table 5) provide a first hint as to why these large differences in income might have emerged. In equal division counties, the percentage of the population with a college degree is about 50 percent of a SD higher (see Table 5). Simultaneously, the share of people with a vocational degree is lower, while the share of people without a degree does not differ (not shown). Additionally, equal division counties have higher employment in the trade and service sector and particularly in creative industries. Equal division countries reveal significantly higher labor productivity measured as GDP per hour worked. There are also more firms present (particularly small firms) in equal division counties. These differences suggest that human capital and industry structure contribute to the large income differences today. In the following sections, we will discuss these and further potential channels and, in particular, shed light on the importance of industry structure in dimensions of innovation and structural change.

\subsection{Robustness Checks}

We next assess whether the long-term relationship between equal division inheritance and longterm outcomes might be spurious and driven by other long-term differences between equal and unequal division inheritance counties. We first show that equal division counties did not have significant advantages in economic development before industrialization started. The large income gaps between equal and unequal division counties today might be driven by unobserved characteristics which have made equal division counties better off ever since. As measures for pre-industrial wealth and development are rare and hardly available at a geographically disaggregated level for the whole German territory ${ }^{19}$, we draw on different data sets and subsamples that provide evidence that equal division counties were not better off until the end of the $19^{t h}$ century. Our analysis includes four observable determinants of long-term growth: (1) agricultural productivity measured directly by potential caloric output per hectare per year, average farm sizes, and Prussian grain yields; (2) population density, used as a long-run measure of

\footnotetext{
${ }^{19}$ Germany was split into independent kingdoms and principalities until German unification in 1871.
} 
development; (3) early economic progress, which is examined by Prussian census data on early industrialization, employment, and wages; (4) human capital development as covered by Prussian educational censuses.

Agricultural Productivity We test whether equal division counties had more favorable conditions for agriculture that might have contributed to different long-term development trajectories. An index of caloric output per hectare per year before the year 1500 constructed by Galor \& Özak (2016) is the outcome variable in column 1 of Table 6. Although the coefficient is positive, it is not robust to the inclusion of controls and vanishes in the RD specification. In addition to differences in land, there might be discrepancies between potential productivity of land and realized output. In column 2 we draw on data on grain yields from Prussia in 1878 which show slightly lower yields in equal division counties, although the difference is far from being economically or statistically significant. These results provide evidence for the hypothesis that agricultural productivity was similar in equal division and unequal division counties.

Population Density Long-term data with direct evidence on levels of economic development is scarce so we draw on urban population data from year 1500 onwards based on (Bairoch et al. 1988) to assess measures of development before the Industrial Revolution in equal and unequal division areas. We find that the density of urban population developed similarly in equal and unequal division areas (Figure 4). If anything, population density is slightly lower throughout in equal division areas. A potential objection to the use of urban population data in the context of our study might be that rural population density could be a better measure for development in the context of agricultural inheritance rules. As shown in Table 7, the population density in Prussia in 1816 was not higher in equal division counties. For the sample of the whole German territory we show that the density is still not significantly higher in equal division counties by 1895 but we can detect relative increases by 1907. This increase in the population density from 1895 to 1907 is significantly higher in equal division counties than in unequal division counties which is, however, driven by counties which surround independent cities. Excluding these counties from the sample eliminates statistical significance. 
Early Industrialization, Employment, Income, and Wages Drawing on Prussian data, we can assess the relationship between inheritance regimes and measures of early industrialization. Prussian censuses are available from 1816 on and cover disaggregated data at the level of historical counties. ${ }^{20}$ Although Prussia had only very few equal division counties, Table A8 shows that our main results on inequality also hold in a subsample of (historical) Prussia. Data on the number of factories, mills, and looms in 1821 shed light on the economic situation of equal division counties before industrialization started. Self-employment out of agriculture, and employment in manufacturing in 1882 as well as income and county taxes in 1878 and daily wages in 1892 show if industrialization had a positive effect in equal division counties very quickly.

Table 8 shows that there are hardly any significant differences between equal and unequal division counties in Prussia. If anything, coefficients are negative for the density of factories, mills, and looms, suggesting that adoption of new technologies must have started later than 1821. In 1882, there are also no differences in the percentage of people who are self-employed (outside of agriculture) and in the percentage of people working in manufacturing.

For income and wages, Table A10 shows that there are no significant positive effects of equal division and various measures of revenues from income and local county taxes. The difference in daily wages for males is also very small and insignificant.

Human Capital We rely on Prussian educational censuses which document the number of schools, students, and literacy rates early on to shed light on the human capital stock and development in equal and unequal division counties. Table A11 reveals that the percentage of people who could read and write and the percentage of illiterate people were not significantly different between equal and unequal division counties in 1871 when including our controls or RD approach. There are no differences between equal and unequal division counties in school density or pupils in pre-industrial 1816 or at the onset of industrialization in 1886.

Bringing the results on agricultural productivity, population, early industrialization, income, and education together, reveals that equal division counties did not have more advantageous starting conditions than unequal division counties before the Industrial Revolution. This

\footnotetext{
${ }^{20}$ More information about Prussian census data is given in Becker et al. (2014).
} 
allows us to rule out a broad class of potential confounders that could have contributed to the large differences in outcomes we observe in 2014.

\section{Potential Mechanisms}

Why are equal division counties featuring higher income, wealth and education levels today? In this section, we further investigate the potential pathways through which inheritance rules may have affected long-term outcomes in equal and unequal division areas. Throughout the first half of the 20th century, agricultural income lost importance in relation to industrial income. But the joint production of manufacturing and agricultural products under one roof remained a widespread phenomenon until the 1950s, particularly in equal division areas (Lerner 1965, p.326). This industrial by-employment proved crucial for the long-run industrial geography of Germany: new factories were set up in equal division areas to employ workers from those small domestic workshops. This phenomenon occurred first in traditional industries like the tobacco, textile or furniture and later in automotive, automotive supplier, chemical, pharmaceutical and electronics industries (Kistler 1954, Lerner 1965). We argue that inheritance rules created both an incentive and an opportunity for farmers to engage in industrial by-employment and, ultimately, become entrepreneurs. The entrepreneurial businesses or the cultures they created may have, in turn, provided the ground for long-term economic growth.

\subsection{Incentives for Industrial By-Employment}

The small and fragmented peasant holdings in equal division areas created an incentive to engage in industrial by-employment as compensatory strategy (Herrigel 2000). According to Eiler (1984, p.81), families with farms smaller than 3 ha were forced to engage in by-employment in order to nourish the family. As shown in Table 2, equal division areas had significantly more farms with less than 2 ha or with 2-5 ha. We find a significant effect of farm size and soil quality on (innovative) manufacturing interacting our equal division indicator with farm size and soil quality. The smaller the average farm in an equal division county, the higher was employment in (innovative) manufacturing in equal division areas (Columns 3 (6) of Table 10). Further, the lower the soil quality in equal division areas, the higher was employment in 
(innovative) manufacturing in equal division areas (see columns 2 (5) of Table 10). Finally, innovative activity measured by patents is higher in equal division areas if soil quality is lower (see columns 2, 4 and 6 of Table 11). The patent effect is only significant for the reduced sample of our RD specification. We will discuss the role of innovation in more detail in the following Section 6.2 .

\subsection{The Role of Entrepreneurship}

A class of models hypothesizes that a more equal distribution of wealth may increase longterm growth by giving broader parts of the population the chance to become skilled workers or entrepreneurs (see, e.g., Galor \& Zeira 1993, Banerjee \& Newman 1993, Ghatak \& Nien-Huei Jiang 2002, Galor \& Moav 2004). Compared to a situation in which a large part of the population has essentially no wealth, a more even distribution of wealth can provide a buffer to absorb the potential risks of becoming an entrepreneur, investing in human capital, or innovating, or it can alleviate credit constraints in parts of the population, all of which have favorable consequences for growth. Additionally, a more equal wealth distribution might induce individuals to take greater risks if they care for their relative status (Robson 1992). We discuss the evidence for more entrepreneurship, higher innovation and less credit constraints in equal division areas.

Entrepreneurship Our results support an occupational choice mechanism, through which landholding inequality may have affected long-term outcomes. First, we find that per capita business incomes are significantly higher in equal division areas in Baden and Württemberg in 1907, whereas per capital real estate income, capital income and labor incomes are not significantly different in equal and unequal division areas (see Table A15). Second, considering a rough proxy for entrepreneurial activity, we find that equal division countries have a higher percentage of self-employed people out of agriculture in 1925 (see Table A16). These entrepreneurial activities in equal division areas may have provided the foundation for more firms, higher incomes and higher productivity observed today. ${ }^{21}$

\footnotetext{
${ }^{21}$ Additionally, there is some weak evidence that the density of middle schools and the share of middle-school pupils is slightly higher in equal division counties. These schools were primarily attended by students who wanted to become an apprentice in a particular trade. These additional results are not robust across specifications and the effects are only imprecisely estimated but are broadly consistent with landholding inequality affecting longerterm outcomes through occupational choice.
} 
Innovation Employment in innovative branches of manufacturing was higher in equal division areas. We distinguish between 163 occupations in manufacturing in 1907 and follow Streb et al. (2006) who categorize metal working, industry of machines and instruments, chemical industry, printing, and photography as innovative branches based on the number of patents between 1877 and 1914. Table 10 shows the effect of equal division and employment in innovative manufacturing occupations. The coefficient is nearly identical to that in Table 9, which leads us to the conclusion that the additional employment in manufacturing comes almost entirely from occupations in innovative branches.

Patent data of Streb et al. (2006) provide further evidence that innovative activity was higher in equal division counties from 1877 to 1914 (see Table 11). The positive correlation holds when using an indicator variable for having filed a patent in that time, using a log of the total number of patents ${ }^{22}$ to include only counties with patenting activity, and when using the log total number of patents including the counties with no patenting activity as zeros. The magnitude is quite large at about a third of a SD.

Credit Constraints People may be able to borrow only limited amounts because of capital market imperfections. Theoretically, it is not clear if inequality or equality creates growth in models with credit constraints. Small land holdings serving as collateral could have alleviated credit constraints for the large number of small peasants in equal division areas. On the other hand, larger estates could have been the precondition to fund costly investments that then generate growth, as opposed to the situation where all economic agents do not have enough funds for the costly investment.

The financial market in $19^{\text {th }}$ century Germany was still in its infancy. On average, every fifth person held a savings account at a savings bank in 1895, which increased to every fourth person until 1907 (see Table A14). In 1907, average deposits at savings banks amounted to less than a third of average annual income. Accordingly, we find no significant differences between equal and unequal division areas in loans granted by savings banks (Sparkassen) or credit associations (Kreditvereine) in 1895 and 1907 (see Table A14). The absence of higher formal credits does not necessarily imply that reduced credit constraints did not play a role

\footnotetext{
${ }^{22}$ Using the log is necessary as there are some counties with extreme outliers in patenting activity compared to the other counties. While the $50^{\text {th }}$ percentile of filed patents is 1 , the $99^{\text {th }}$ percentile lies at 123 patents and the maximum is 913 filed patents between 1877 and 1914 .
} 
for entrepreneurs in equal division areas. Most of the literature on industrialization in SouthWest Germany stresses the enduring importance of private, informal lending (see Fischer 1972).

Summary As a result of the above factors, we observe an earlier industrial take-off in equal division counties: While there were no significant differences in employment in agriculture and manufacturing in 1882 (see Table A12), equal division areas exhibit significantly lower agricultural employment and higher manufacturing employment in 1895. This gap between equal and unequal division areas opens even further until 1907. Table 9 reveals that the coefficient of manufacturing amounts to about a quarter of an SD and increased by 35 percent of a SD from 1895 to 1907. At the same time, the coefficient of equal division for employment in agriculture decreased by almost the same magnitude from 1895 to 1907.

Our evidence highlights the importance of small firms, which is another long-term result of industrial by-employment in equal division areas. Today, firms in equal division areas are smaller, on average (see column 9 of Table 5), while being more productive at the same time (see column 7 of Table 5). According to Herrigel (2000), small- and medium-sized German firms proved able to adapt to the accelerating pace of product and technological change of the new world market conditions in the 1980s, when the era of mass production in post-war Germany came to an end. Smaller firms can adjust more flexibly to changing economic environments and may, by this, ensure long-term economic growth.

Higher long-term growth has resulted in a more widespread distribution of income and wealth. The income share of the top $10 \%$ and the top $1 \%$ is significantly higher in equal division areas. Also, the number of millionaires per capita is significantly higher. Taken together with the observation that top incomes in Germany mostly stem from family businesses (Bartels 2019), the above findings imply that high income comes from and wealth is invested in family firms. At least two channels may have contributed to turn a more even historical distribution into a more uneven distribution today. First, family firms are unlikely to be equally divided among siblings. The desire to leave the business intact in the hands of a single descendant may induce firm owners to give a higher portion of the firm to one child that will take over control of the firm. A larger portion assigned to the controlling heir of the family firm alleviates credit constraints if capital markets are imperfect and, thereby, expand the firm's ability to invest 
(Ellul, Pagano \& Panunzi 2010). Second, large inheritances - here in the form of businesses are more likely to persist over time, while smaller inheritances are depleted through increased consumption (Nekoei \& Seim 2019).

\section{Conclusion}

We have studied long-term consequences of spatial variation in a historical institution, namely agricultural inheritance rules, which regulated the distribution of land since the Middle Ages in Germany. Agricultural inheritance rules vary between unequal division where land is indivisible and is passed on to a single heir and equal division of land among all siblings. We have found that equal division counties had historically lower landholding inequality. This lends support to the canonical theoretical models on inheritance rules and inequality predicting less inequality under an equal division regime than under primogeniture (Stiglitz 1969, Blinder 1973, Pryor 1973, Menchik 1980). We found no evidence for advantages conferred by equal division before the advent of industrialization, which occurred relatively late in Germany. In sharp contrast, we find positive effects of equal division on long-term productivity and income. We find evidence indicating that the equal division of land spurred industrial by-employment, in particular in innovative and entrepreneurial activities. Our evidence suggests that the more equal distribution of land - the key store of wealth for broad parts of the population in $19^{\text {th }}$ century Germany - contributed to today's innovative Mittelstand and long-term productivity. Equal division of land proved to be an inclusive economic institution in the long run. Our evidence further lends support to models in which a more equitable distribution of wealth can spur occupational upgrading and the decision to become an entrepreneur (see, e.g., Galor \& Zeira 1993, Banerjee \& Newman 1993, Ghatak \& Nien-Huei Jiang 2002, Galor \& Moav 2004).

We close with several reflections on the institutional context and potential limitations of our study. Our evidence lends support to the idea that the long-term consequences of institutions are context-dependent and may be particularly important at critical junctures (Acemoglu, Johnson \& Robinson 2005): while equal division and a more equitable distribution of land did not appear to confer advantages before industrialization, they turned out to be an important mediator of the path of industrialization across German regions. A limitation of our study is that while geographic variation in inheritance rules is sharp and local, the origins of differences in 
inheritance rules are not fully understood and institutional differences have existed for centuries before we observe crucial differences in the paths of industrialization. 


\section{References}

Acemoglu, D., Bautista, M. A., Querubín, P. \& Robinson, J. A. (2007), 'Economic and political inequality in development: The case of Cundinamarca, Colombia', NBER Working Paper No. 13208 .

Acemoglu, D., Johnson, S. \& Robinson, J. A. (2001), 'The colonial origins of comparative development: An empirical investigation', American Economic Review 91(5), 1369-1401.

Acemoglu, D., Johnson, S. \& Robinson, J. A. (2005), 'Institutions as a fundamental cause of long-run growth', Handbook of Economic Growth 1, 385-472.

Alesina, A., Giuliano, P. \& Nunn, N. (2013), 'On the origins of gender roles: Women and the plough', The Quarterly Journal of Economics 128(2), 469-530.

Alston, L. J. \& Schapiro, M. O. (1984), 'Inheritance laws across colonies: Causes and consequences', The Journal of Economic History 44(2), 277-287.

Alvaredo, F., Atkinson, A., Piketty, T. \& Saez, E. (2013), 'The top 1 percent in international and historical perspective.', Journal of Economic Perspectives 27(3), 3-20.

Bairoch, P., Batou, J. \& Chevre, P. (1988), The population of European cities. Data bank and short summary of results: 800-1850, Geneva Switzerland Librairie Droz 1988.

Banerjee, A. \& Iyer, L. (2005), 'History, institutions, and economic performance: The legacy of colonial land tenure systems in india', American Economic Review 95(4), 1190-12133.

Banerjee, A., Iyer, L. \& Somanathan, R. (2005), 'History, social divisions, and public goods in rural India', Journal of the European Economic Association 3(2-3), 639-647.

Banerjee, A. V. \& Duflo, E. (2003), 'Inequality and growth: What can the data say?', Journal of Economic Growth 8(3), 267-299.

Banerjee, A. V. \& Newman, A. F. (1993), 'Occupational choice and the process of development', Journal of Political Economy 101(2), 274-298.

Bartels, C. (2019), 'Top incomes in Germany, 1871-2014', Journal of Economic History 79(3), 669-707.

Baten, J. (1999), Nutrition and economic development in Bavaria, 1730-1880, PhD thesis, München.

Baten, J. (2000), 'Height and real wages in the 18th and 19th centuries: An international comparison', Jahrbuch für Wirtschaftsgeschichte 41(1), 61-76.

Becker, H. (1998), Allgemeine Historische Agrargeographie, Teubner.

Becker, S., Cinnirella, F., Hornung, E. \& Woessmann, L. (2014), 'iPEHD - The ifo Prussian Economic History Database', Historical Methods: A Journal of Quantitative and Interdisciplinary History 47(2), 57-66. 
Becker, S. O., Cinnirella, F. \& Woessmann, L. (2010), 'The trade-off between fertility and education: Evidence from before the demographic transition', Journal of Economic Growth 15(3), 177-204.

Behrend, J. F. (1897), Lex Salica, Weimar.

Blanckmeister, F. (1913), Sachsenspiegel, Dresden Sturm.

Bleakley, H. \& Ferrie, J. P. (2016), 'Shocking behavior: Random wealth in antebellum Georgia and human capital across generations', Quarterly Journal of Economics 131(3), 1455-1495.

Blinder, A. (1973), 'A model of inherited wealth', Quarterly Journal of Economics pp. 608-628.

Boserup, E. (1965), The Conditions of Agricultural Growth. The Economics of Agrarian Change under Population Pressure, George Allen \& Uniwin Ltd., London.

Chu, C. Y. C. (1991), 'Primogeniture', Journal of Political Economy 99(1), 78-99.

Cinnirella, F. \& Hornung, E. (2016), 'Landownership concentration and the expansion of education', Journal of Development Economics 121(Supplement C), 135-152.

Cole, J. W. \& Wolf, E. R. (1995), Die unischtbare Grenze. Ethnizität und Ökologie in einem Alpental, Filio Wien, Bozen.

Conley, T. (1999), 'GMM estimation with cross-sectional dependence', Journal of Econometrics 92, $1-45$.

Crouch, D. (2005), The birth of nobility: Social change in England and France: 900-1300, Pearson Education Limited.

Dell, M. (2010), 'The persistent effects of Peru's mining mita', Econometrica 78(6), 1863-1903.

Doepke, M. \& Zilibotti, F. (2008), 'Occupational choice and the spirit of capitalism', Quarterly Journal of Economics 123(2), 747-793.

Duranton, G., Rodríguez-Pose, A. \& Sandall, R. (2009), 'Family types and the persistence of regional disparities in europe', Economic Geography 85(1), 23-47.

Eheberg, T. (1883), Bäuerliche Verhältnisse in Niederbayern, Oberpfalz und dem bayerischen Franken, in 'Bäuerliche Zustände in Deutschland. Band III', Duncker and Humblot, pp. $113-207$.

Eichengreen, B. \& Ritschl, A. (2009), 'Understanding West German economic growth in the 1950s', Cliometrica 3(3), 191-219.

Eiler, K. (1984), Hessen im Zeitalter der industriellen Revolution, Insel.

Ellul, A., Pagano, M. \& Panunzi, F. (2010), 'Inheritance law and investment in family firms', American Economic Review 100(5), 2414-2450.

Fastenmayer, B. (2009), Hofübergabe als Altersversorgung. Generationenwechsel in der Landwirtschaft 1870 bis 195\%, Klostermann Vittorio. 
Fick, L. (1895), 'Die bäuerliche Erbfolgen im rechtsrheinischen Bayern: Nach amtlichen Quellen dargestellt', Münchner volkswirtschaftliche Studien $\mathbf{8}$.

Fischer, W. (1972), Wirtschaft und Gesellschaft im Zeitalter der Industrialisierung, Vandenhoeck \& Ruprecht.

Fogel, R. (1986), Human growth: a comprehensive treatise, in F. Falkner \& J. Tanner, eds, 'Physical growth as a measure of the economic well-being of populations: the eighteenth and nineteenth centuries.', New York, Plenum Press, pp. 263-81.

Fritsch, M. \& Wyrwich, M. (2014), 'The long persistence of regional levels of entrepreneurship: Germany, 1925-2005', Regional Studies 48(6), 955-973.

Fritsch, M. \& Wyrwich, M. (2016), 'The effect of entrepreneurship on economic development - an empirical analysis using regional entrepreneurship culture', Journal of Economic Geography 17, 157-189.

Galor, O. \& Moav, O. (2004), 'From physical to human capital accumulation: Inequality and the process of development', Review of Economic Studies 71(4), 1001-1026.

Galor, O., Moav, O. \& Vollrath, D. (2009), 'Inequality in landownership, the emergence of human-capital promoting institutions, and the great divergence', The Review of Economic Studies 76(1), 143-179.

Galor, O. \& Özak, Ö. (2016), 'The agricultural origins of time preference', American Economic Review 106(10), 3064-3103.

Galor, O. \& Zeira, J. (1993), 'Income distribution and macroeconomics', The Review of Economic Studies 60(1), 35-52.

Gerschenkron, A. (1966), Economic Backwardness in Historical Perspective: A Book of Essays, Harvard University Press.

Gerschenkron, A. (1989), Bread and Democracy in Germany, Cornell University Press.

Ghatak, M. \& Nien-Huei Jiang, N. (2002), 'A simple model of inequality, occupational choice, and development', Journal of Development Economics 69(1), 205-226.

Glaeser, E. L. \& Kerr, W. R. (2009), 'Local industrial conditions and entrepreneurship: How much of the spatial distribution can we explain?', Journal of Economics $\&$ Management Strategy 18(3), 623-663.

Glaeser, E. L., La Porta, R., Lopez-de Silanes, F. \& Shleifer, A. (2004), 'Do institutions cause growth?', Journal of Economic Growth 9, 271-303.

Grossherzogliches Ministerium des Inneren (1883), 'Erhebungen über den Stand der Landwirtschaft im Grossherzogtum Baden'.

Habakkuk, H. J. (1955), 'Family structure and economic change in nineteenth-century europe', The Journal of Economic History 15(01), 1-12. 
Hartke, W. \& Westermann, E. (1940), 'Die Vererbung der bäuerlichen Liegenschaften in Deutschland bis zum Erlass des Reichserbhofgesetzes', Petermanns Geographische Mitteilungen $\mathbf{8 6 .}$

Helmolt, H. (1902), The extent of the Hansa about 1400, in 'History of the World', Vol. 7, Heiemann, Friedrich Graf.

Herrigel, G. (2000), Industrial constructions: The sources of German industrial power, Structural Analysis in the Social Sciences (Book 9), Cambridge University Press.

Huppertz, B. (1939), Räume und Schichten bäuerlicher Kulturformen in Deutschland: Ein Beitrag zur deutschen Bauerngeschichte, Röhrscheid.

Jarvis, A., Reuter, H., Nelson, A. \& Guevara, E. (2006), 'Hole-filled seamless SRTM data v3, international centre for tropical agriculture', Cali Columbia .

Kaiserliches Statisisches Amt (1897), Berufsstatistik der kleineren Verwaltungsbezirke: Berufsu. Gewerbezählung vom 14. Juni 1895, Statistik des Deutschen Reichs, Technical report.

Kaiserliches Statisisches Amt (1910), Berufsstatistik: Berufs- und Betriebszählung vom 12. Juni 1907: Kleinere Verwaltungsbezirke, Statistik des Deutschen Reichs, Technical report.

Kaiserliches Statisisches Amt (1912), Statistik des Deutschen Reichs: Landwirtschaft Betriebsstatistik, Technical report.

Kaiserliches Statistisches Amt (1877), Statistik des Deutschen Reichs, Band XXV: Zur Eisenbahn- und Bevoelkerungs, Statistik des Deutschen Reichs in der Periode 1867 bis 1875, Technical report.

Kistler, F. (1954), Die wirtschaftlichen und sozialen Verhältnisse in Baden 1849-1870, Albert.

Konversationslexikon, M. G. (1905), Verteilung der Konfessionen im Deutschen Reich, in 'Meyers Grosses Konversationslexikon', Meyers.

Krafft, K. (1930), Anerbensitte und Anerbenrecht in Württemberg, Kohlhammer.

Kunz, A. (2004), Navigable Waterways in the German Reich, 1903, Institute of European History.

Kuznets, S. (1955), 'Economic growth and income inequality', American Economic Review 45(1), 1-28.

La Porta, R., Lopez-de Silanes, F., Shleifer, A. \& Vishny, R. W. (1998), 'Law and finance', Journal of Political Economy 106(6), 1113-1155.

Lerner, F. (1965), Wirtschafts- und Sozialgeschichte des Nassauer Raumes 1816-1964, Nassauische Sparkasse.

Menchik, P. L. (1980), 'Primogeniture, equal sharing, and the U.S. distribution of wealth', The Quarterly Journal of Economics 94(2), 299-316. 
Miaskowski, A. v. (1884), Das Erbrecht und die Grundeigenthumsvertheilung im Deutschen Reiche: Ein socialwirthschaftlicher Beitrag zur Kritik und Reform des deutschen Erbrechts, Schriften des Vereins für Socialpolitk, Duncker \& Humblot.

MPIDR [Max Planck Institute for Demographic Research] and CGG [Chair for Geodesy and Geoinformatics, University of Rostock] (2011), 'MPIDR Population History GIS Collection', Rostock .

Nekoei, A. \& Seim, D. (2019), How do inheritances shape wealth inequality? Theory and evidence from Sweden.

Nunn, N. (2009), 'The importance of history for economic development', Annual Review of Economics 1, 65-92.

Piketty, T. (2003), 'Income inequality in France, 1901-1998', Journal of Political Economy 111(5), 1004-1042.

Piketty, T. \& Saez, E. (2014), 'Inequality in the long run', Science 344(6186), 838-843.

Pryor, F. (1973), 'Simulation of the impact of social and economic institutions on the size distribution of income and wealth', American Economic Review 63, 50-72.

Rink, A. \& Hilbig, H. (2019), 'Do inheritance customs affect political and social inequality?', American Journal of Political Science 63(4), 758-773.

Robson, A. (1992), 'Status, the distribution of wealth, private and social attitudes to risk', Econometrica 60(4), 837-857.

Röhm, H. (1957), Die Vererbung des landwirtschaftlichen Grundeigentums in BadenWürttemberg, Vol. 102, Bundesanstalt für Landeskunde.

Röhm, H. (1961), 'Geschlossene Vererbung und Realteilung in der Bundesrepublik Deutschland', Abhandlungen des Deutschen Geographentages in Köln pp. 288-304.

Rösener, W. (2012), 'Vererbungsstrategien und bäuerliche Familienwirtschaft in der vormodernen Agrargesellschaft', Zeitschrift für Agrargeschichte und Agrarsoziologie 60(2), 14-34.

Rouette, S. (2003), Erbrecht und Besitzweitergabe: Praktiken in der ländlichen gesellschaft Deutschlands, Diskurse in Politik und Wissenschaft, in 'Ländliche Gesellschaften in Deutschland und Frankreich, 18.-19. Jahrhundert', Vandenhoeck \& Ruprecht, pp. 145166.

Schröder, K.-H. (1979), Zur Frage geographischer Ursachen der Realteilung in der alten Welt, in 'Fragen geographischer Forschung, Festschrift des Instituts für Geographie zum 60. Geburtstag von Adolf Leidlmair', pp. 467-482.

Schröder, R. (1870), Rechtskarte von Deutschland zur Veranschaulichung der auf dem Gebiete des Privatrechts herrschenden Rechtssysteme im Jahre 1870, in 'Petermanns geographische Mitteilungen', Perthes.

Sering, M. (1897), Die Vererbung des ländlichen Grundbesitzes im Königreich Preussen, Paul Parey. 
Shepherd, W. (1911), Map of the rise of Frankish empire, from 481 to 814, in 'Historical Atlas', Henry Holt and Company, New York.

Smith, C. (2019), 'Land concentration and long-run development: Evidence from the frontier united states', MIT Working Paper.

Stiglitz, J. E. (1969), 'Distribution of income and wealth among individuals', Econometrica 37(3), 382-397.

Streb, J., Baten, J. \& Yin, S. (2006), 'Technological and geographical knowledge spillover in the German empire 1877-1918', Economic History Review 59(2), 347-373.

Tilly, R. H. (1969), German industrialization, in M. Teich \& R. Porter, eds, 'The Industrial Revolution in National Context: Europe and the USA', Cambridge University Press, pp. 95125.

Tur-Prats, A. (2018), 'Family types and intimate-partner violence: A historical perspective', Review of Economics and Statistics 101(5), 878-891.

van Zanden, J., Baten, J., d'Ercole, M. M., Rijpma, A., Smith, C. \& Timmer, M. (2014), 'How was life? Global well-being since 1820', OECD Publishing .

Verein für Socialpolitik (1883), Bäuerliche Zustände in Deutschland I-III, Duncker \& Humblot.

Weber, M. (1924), Abriss der universalen Sozial- und Wirtschaftsgeschichte, Duncker \& Humblot.

Wegge, S. A. (1998), 'Chain migration and information networks: Evidence from nineteenthcentury Hesse-Cassel', Journal of Economic History 58, 957-986.

Ziblatt, D. (2008), 'Does landholding inequality block democratization? A test of the "bread and democracy" thesis and the case of Prussia', World Politics 60(04), 610-641. 
Figures and Tables 
Figure 1: Illustration: Prevalence of Inheritance Rules in Württemberg, 1905-1910

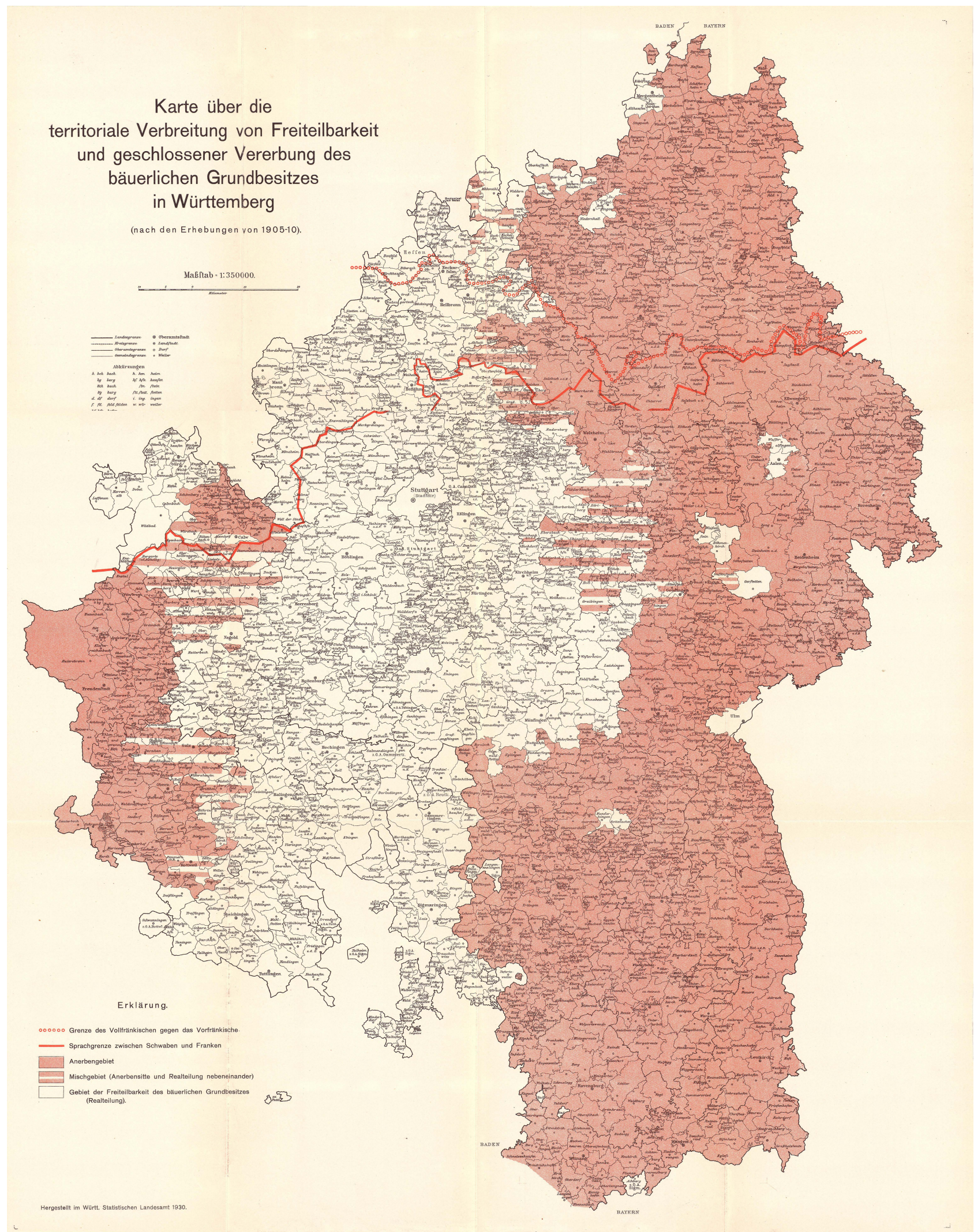

Source: The figure illustrates the local variation of inheritance rules for agricultural land in the South-Western German region of Württemberg. Areas depicted in white feature equal division rules, areas in red unequal division. The figure illustrates the fine-grained nature of the variation in inheritance rules, which traverses geographic boundaries, e.g., from one village to the next within the same county, as well as linguistic borders. To illustrate, the red line denotes the linguistic border between Swabian and East Franconian German. The figure is taken from Krafft (1930). 
Figure 2: Prevalence of Inheritance Rules: Equal and Unequal Division

(a) German Empire

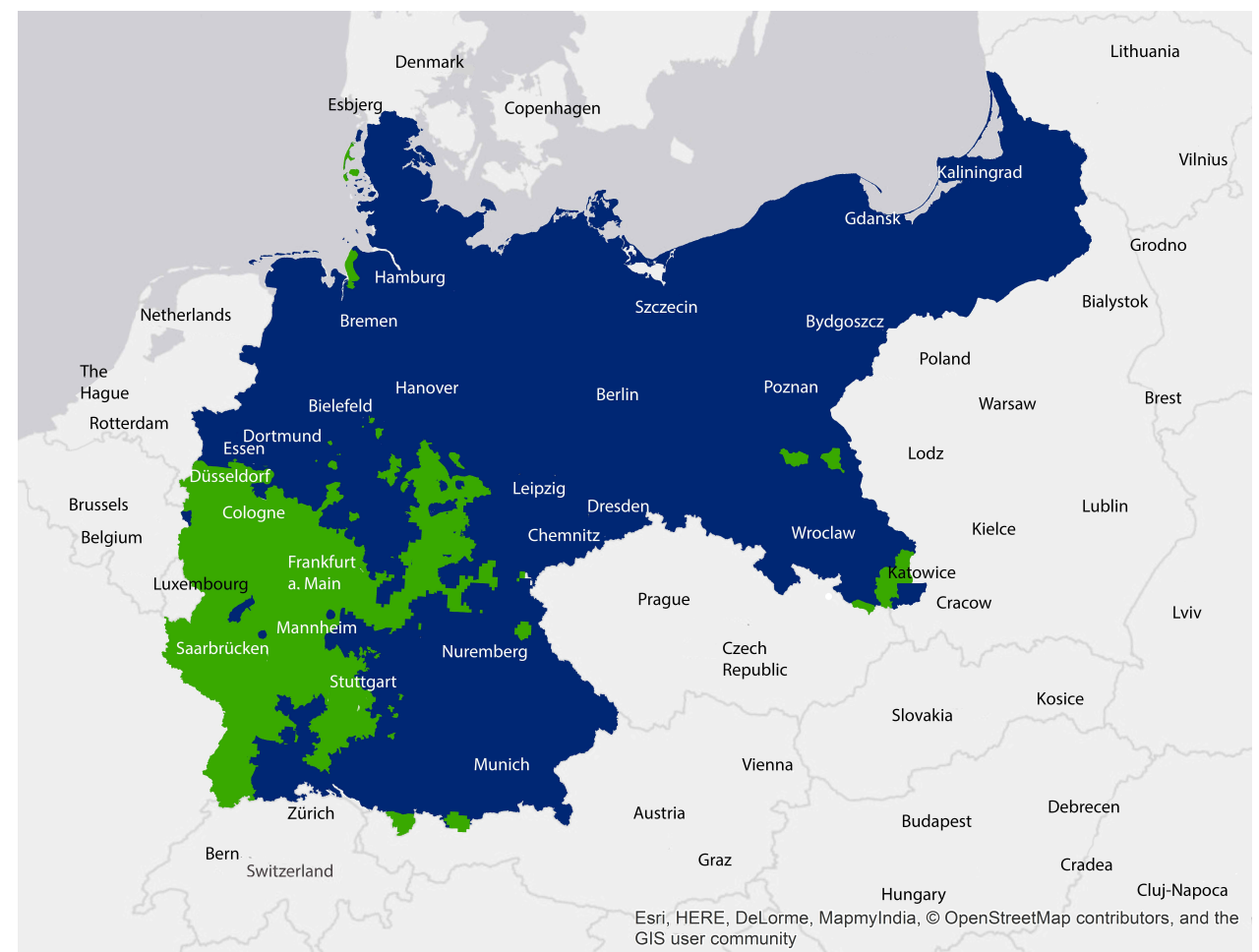

(b) Regression Discontinuity Sample: Areas Within $35 \mathrm{~km}$ of Inheritance Regime Border

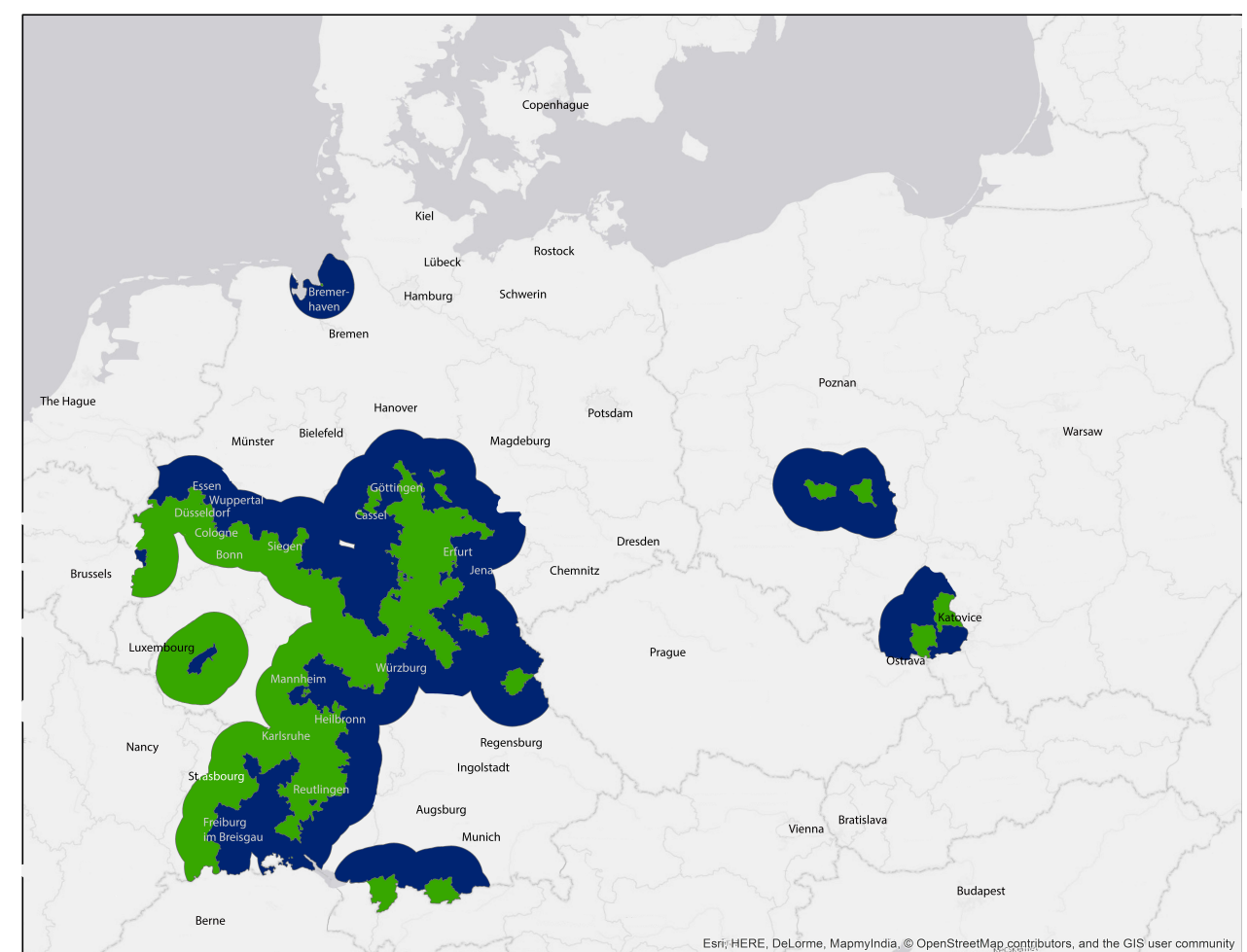

The figure shows a map of the prevalence of inheritance rule in the German Empire. Dark blue denotes areas with unequal sharing or indivisibility of land. Green denotes areas with equal sharing of land among children. Panel (b) plots areas less than $35 \mathrm{~km}$ away from the nearest border with the opposite inheritance regime; the corresponding counties constitute our regression discontinuity sample. 
Figure 3: Predictors of Equal Division and Long-Term Development Are Smooth at the Border

(a) Outcome: Equal Inheritance Predicted Based on Covariates

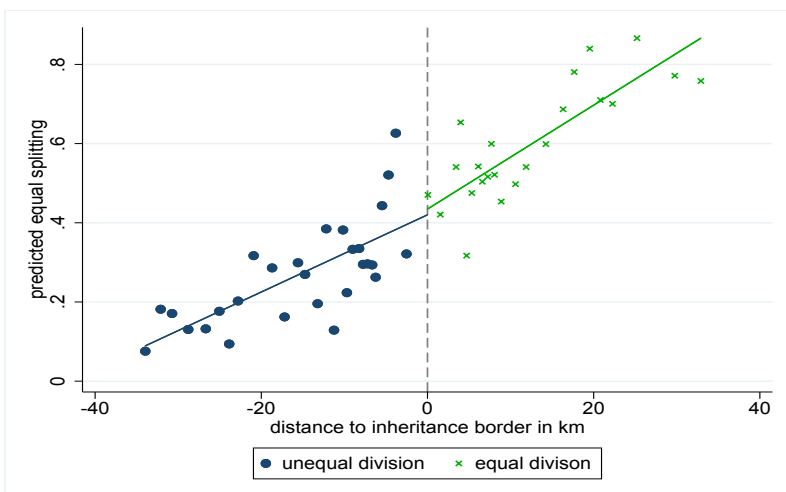

(b) Outcome: Ln GDP Per Capita (2014) Predicted Based on Covariates

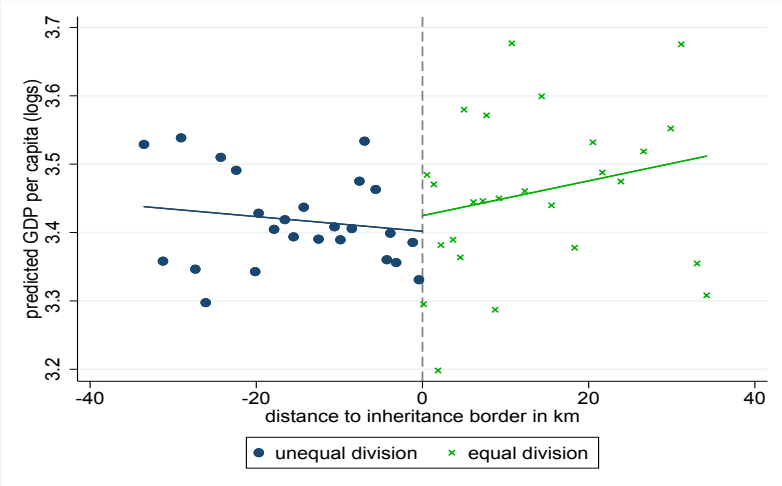

(c) Outcome: Modern Ln Income Per Capita (2014) Predicted Based on Covariates

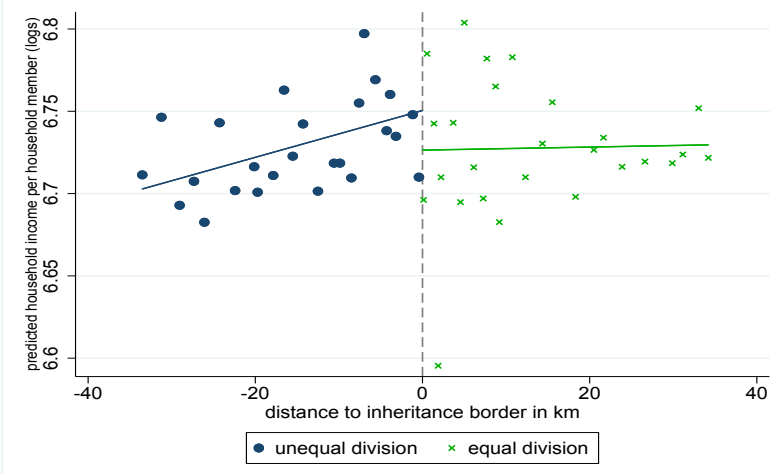

Note: The figures plot regression discontinuity specifications using binned scatter plots and local polynomial specification in a 35 $\mathrm{km}$ bandwidth. The running variable is distance to the nearest inheritance regime change border. The outcome variables are predicted based on the control variables reported in Table 1 . The outcome variable in panel (a) is an indicator for a county having an equal division inheritance regime, the outcome variable in panel (b) is the logarithm of GDP per capita in 2014, the outcome variable in panel (c) is average log household income per household member in 2014. 
Figure 4: Urban Population Density (1500 to 1907)

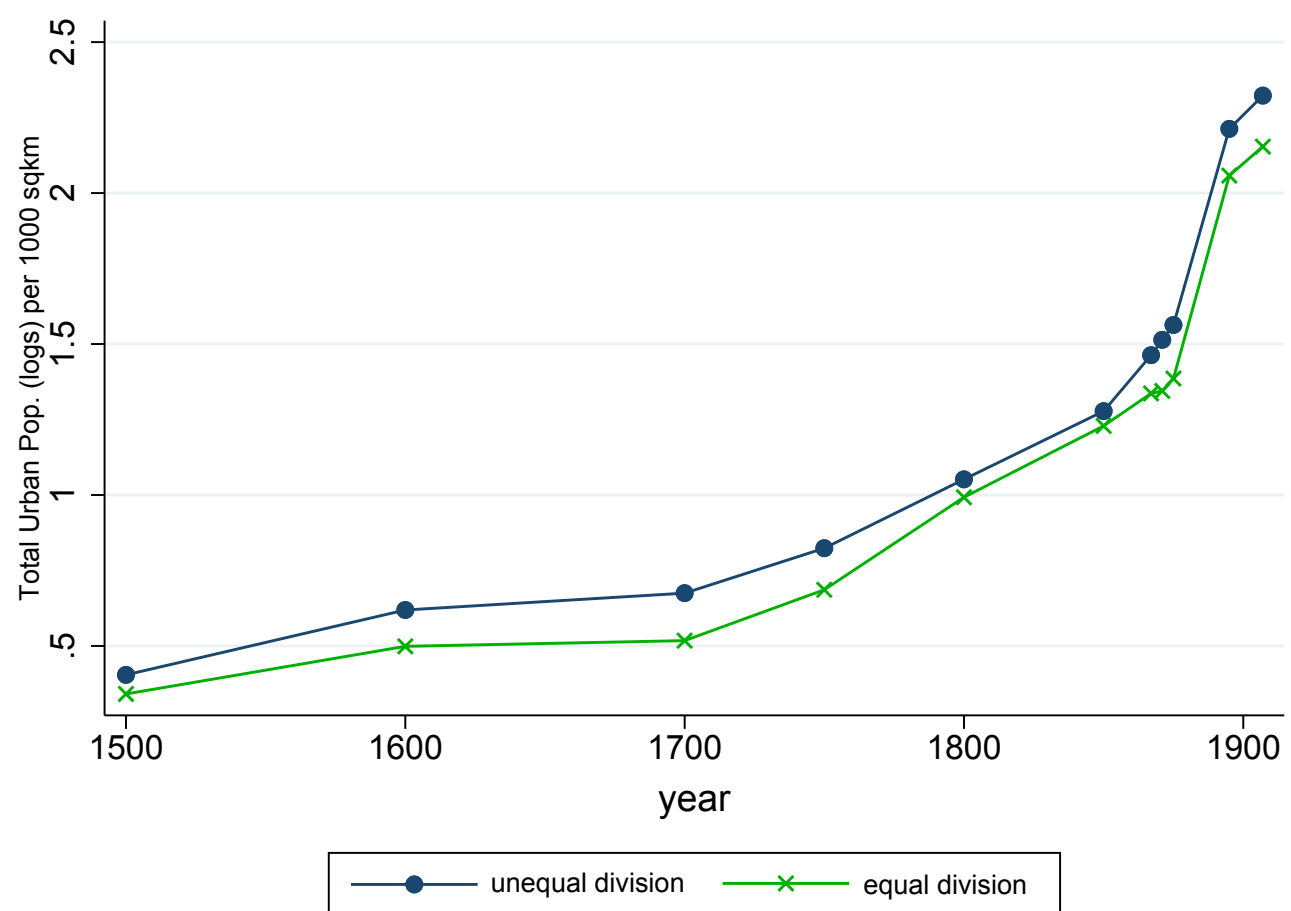

Source: The figure reports urban population density in cities by inheritance regime based on the data in Bairoch et al. (1988). The density measure is log population per $1000 \mathrm{~km}^{2}$. 
Figure 5: RD Results by Distance to the Border: Historical Inequality
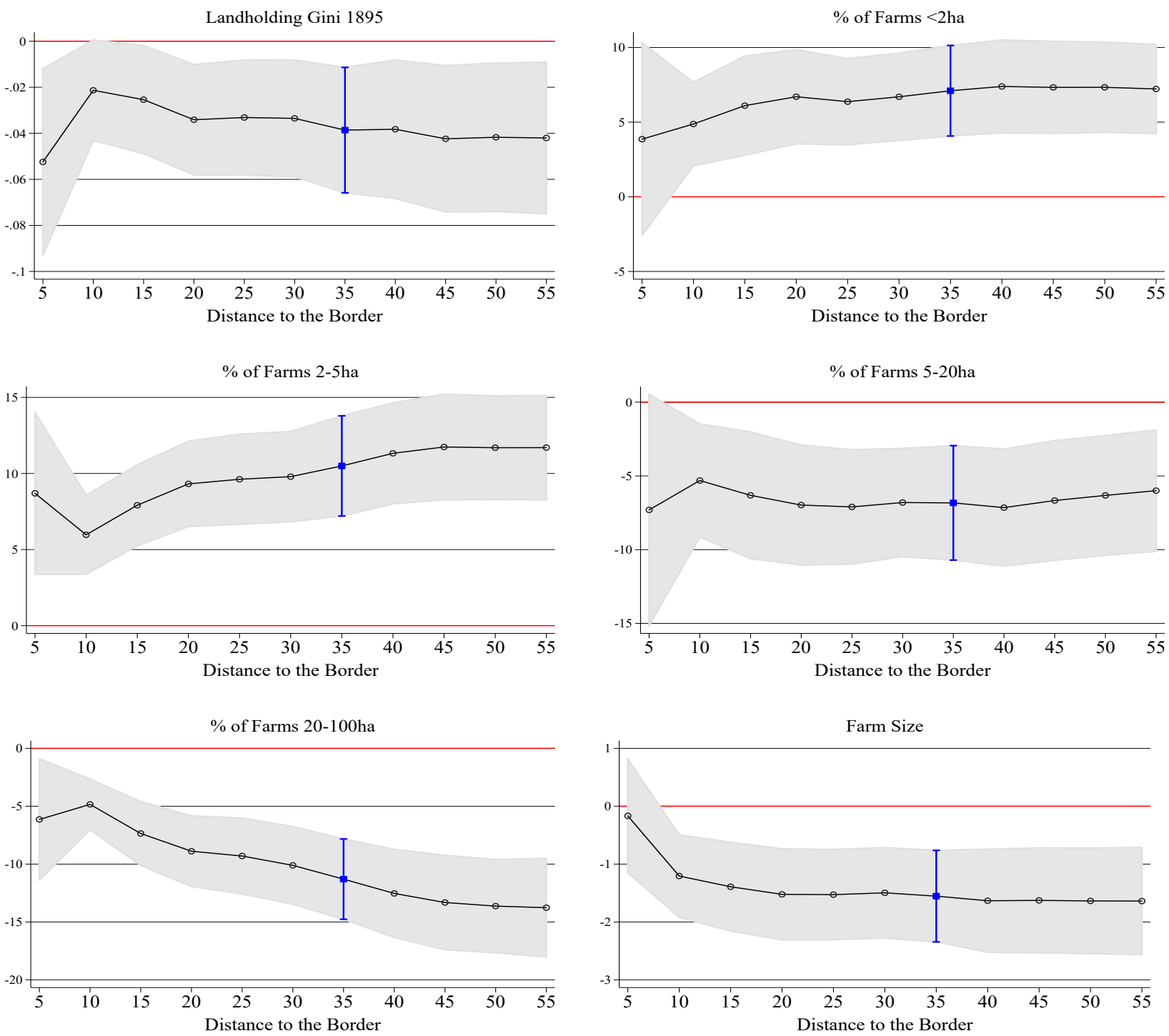

Note: The figure plots the effect of equal division on the outcome reported in the title of the figure. The sample is reduced to counties near the border of the inheritance rule varying distance to the border. 
Figure 6: RD Results by Distance to the Border: Income Measures 2014
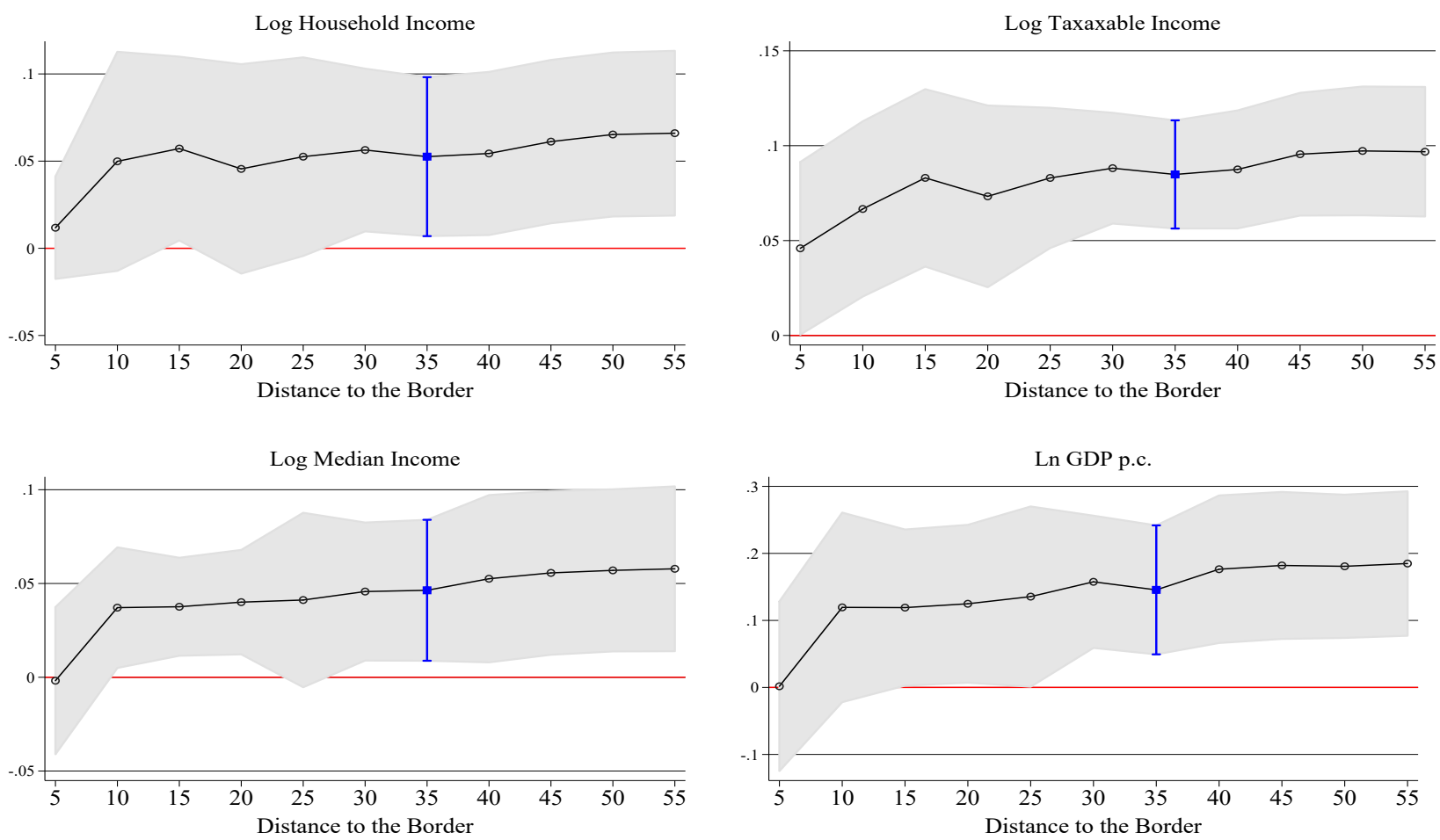

Note: The figure plots the effect of equal division on the outcome reported in the title of the figure. The sample is reduced to counties near the border of the inheritance rule varying distance to the border. 
Figure 7: RD Results by Distance to the Border: Inequality Measures 2014 and 1995
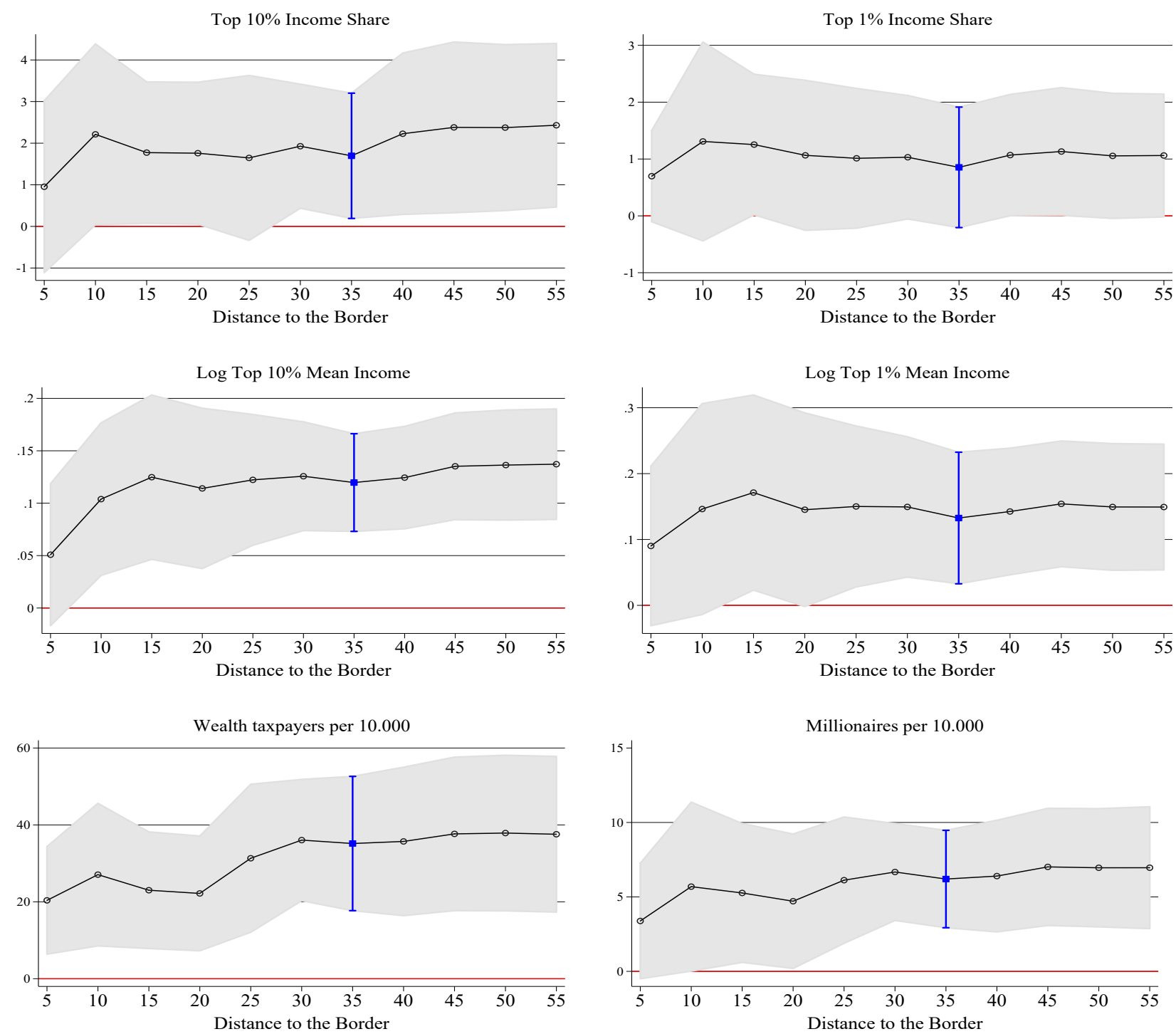

Note: The figure plots the effect of equal division on the outcome reported in the title of the figure. The sample is reduced to counties near the border of the inheritance rule varying distance to the border. 
Table 1: Summary Statistics

\begin{tabular}{|c|c|c|c|c|c|}
\hline & \multicolumn{3}{|c|}{ Summary statistics } & \multicolumn{2}{|c|}{ T-test } \\
\hline & & unequal division & equal division & difference & se \\
\hline \multicolumn{6}{|l|}{ Geographic Controls } \\
\hline temperature in ${ }^{\circ} \mathrm{C}$ & $\begin{array}{l}\text { mean } \\
\text { sd }\end{array}$ & $\begin{array}{c}8.125 \\
(0.784)\end{array}$ & $\begin{array}{c}8.820 \\
(0.903)\end{array}$ & 0.241 & $0.142^{*}$ \\
\hline precipitation in $\mathrm{mm}$ & $\begin{array}{l}\text { mean } \\
\text { sd }\end{array}$ & $\begin{array}{c}59.769 \\
(12.345)\end{array}$ & $\begin{array}{l}61.940 \\
(8.543)\end{array}$ & -3.594 & 2.313 \\
\hline elevation in $\mathrm{m}$ & $\begin{array}{l}\text { mean } \\
\text { sd }\end{array}$ & $\begin{array}{c}249.349 \\
(223.019)\end{array}$ & $\begin{array}{c}313.408 \\
(159.704)\end{array}$ & -45.241 & $23.185^{*}$ \\
\hline roughness: difference in elevation & $\begin{array}{l}\text { mean } \\
\text { sd }\end{array}$ & $\begin{array}{c}3.820 \\
(3.172)\end{array}$ & $\begin{array}{c}6.347 \\
(3.352)\end{array}$ & 0.643 & 0.469 \\
\hline distance to navigable waterway in $\mathrm{km}$ & $\begin{array}{l}\text { mean } \\
\text { sd }\end{array}$ & $\begin{array}{c}25.840 \\
(21.606)\end{array}$ & $\begin{array}{c}20.704 \\
(16.831)\end{array}$ & -3.930 & 2.912 \\
\hline \multicolumn{6}{|l|}{ soil characteristics } \\
\hline soil: share of sand & $\begin{array}{l}\text { mean } \\
\text { sd }\end{array}$ & $\begin{array}{c}0.219 \\
(0.274)\end{array}$ & $\begin{array}{c}0.012 \\
(0.074)\end{array}$ & -0.096 & $0.033^{* * *}$ \\
\hline soil: share of loam, sand, silt & $\begin{array}{l}\text { mean } \\
\text { sd }\end{array}$ & $\begin{array}{c}0.609 \\
(0.340)\end{array}$ & $\begin{array}{c}0.300 \\
(0.269)\end{array}$ & -0.145 & $0.053^{* * *}$ \\
\hline soil: share of loess & $\begin{array}{l}\text { mean } \\
\text { sd }\end{array}$ & $\begin{array}{c}0.098 \\
(0.189)\end{array}$ & $\begin{array}{c}0.130 \\
(0.202)\end{array}$ & -0.014 & 0.042 \\
\hline \multicolumn{6}{|l|}{ Cultural Controls } \\
\hline Frankish territory in 507 AD & $\begin{array}{l}\text { mean } \\
\text { sd }\end{array}$ & $\begin{array}{c}0.093 \\
(0.291)\end{array}$ & $\begin{array}{c}0.473 \\
(0.500)\end{array}$ & 0.275 & $0.075^{* * *}$ \\
\hline protestants in $\%$ & $\begin{array}{l}\text { mean } \\
\text { sd }\end{array}$ & $\begin{array}{c}65.272 \\
(38.008)\end{array}$ & $\begin{array}{c}47.368 \\
(33.602)\end{array}$ & -8.317 & 6.709 \\
\hline Hanseatic league & $\begin{array}{l}\text { mean } \\
\text { sd }\end{array}$ & $\begin{array}{c}0.404 \\
(0.491)\end{array}$ & $\begin{array}{c}0.103 \\
(0.304)\end{array}$ & -0.249 & $0.074^{* * *}$ \\
\hline \multicolumn{6}{|l|}{ general law } \\
\hline common law & $\begin{array}{l}\text { mean } \\
\text { sd }\end{array}$ & $\begin{array}{c}0.449 \\
(0.498)\end{array}$ & $\begin{array}{c}0.433 \\
(0.497)\end{array}$ & -0.100 & 0.120 \\
\hline Prussian & $\begin{array}{l}\text { mean } \\
\text { sd }\end{array}$ & $\begin{array}{c}0.453 \\
(0.498)\end{array}$ & $\begin{array}{c}0.076 \\
(0.265)\end{array}$ & -0.236 & $0.085^{* * *}$ \\
\hline Saxonian & $\begin{array}{l}\text { mean } \\
\text { sd }\end{array}$ & $\begin{array}{c}0.040 \\
(0.196)\end{array}$ & $\begin{array}{c}0.000 \\
(0.000)\end{array}$ & & \\
\hline Code Napoleon & $\begin{array}{l}\text { mean } \\
\text { sd }\end{array}$ & $\begin{array}{c}0.015 \\
(0.121)\end{array}$ & $\begin{array}{c}0.371 \\
(0.484)\end{array}$ & 0.329 & $0.095^{* * *}$ \\
\hline Badish & $\begin{array}{l}\text { mean } \\
\text { sd }\end{array}$ & $\begin{array}{c}0.043 \\
(0.203)\end{array}$ & $\begin{array}{c}0.121 \\
(0.326)\end{array}$ & 0.007 & 0.005 \\
\hline observations & obs & 676 & 224 & & \\
\hline
\end{tabular}

The table shows summary statistics for our control variables in rural German counties in 1895. Column 1 gives the mean and standard deviation of the control variables in unequal division counties while column 2 shows means and standard deviation for equal division counties. Column 3 and 4 show the difference between these groups and test if the difference is equal to zero. The difference and the standard errors stem from a regression which includes longitude, latitude, state-fixed effects, clusters standard errors on the district (Regierungsbezirk) level and weighs observations by population. Notes: ${ }^{*} \mathrm{p}<0.1,{ }^{* *} \mathrm{p}<0.05,{ }^{* * *} \mathrm{p}<0.01$ 
Table 2: Equal Division and Landholding Inequality 1895

\begin{tabular}{|c|c|c|c|c|c|c|c|c|}
\hline & \multicolumn{2}{|c|}{ Landholding Gini 1895} & \multicolumn{4}{|c|}{$\%$ of Farms in Size Category } & \multirow{3}{*}{$\begin{array}{c}\frac{\text { Farm Size }}{(7)} \\
\text { in ha }\end{array}$} & \multirow{3}{*}{$\begin{array}{c}\frac{\text { Number of Farms }}{(8)} \\
\text { per } 1000 \text { Inhabitants }\end{array}$} \\
\hline & $(1)$ & $(2)$ & $(3)$ & $(4)$ & $(5)$ & $(6)$ & & \\
\hline & Linear RD Poly. & Quad. RD Poly. & $<2$ ha & $2-5$ ha & $5-20$ ha & $20-100$ ha & & \\
\hline \multicolumn{9}{|l|}{ Panel A. OLS } \\
\hline \multirow[t]{3}{*}{ Equal Division } & $-0.0382^{* *}$ & $-0.0353^{*}$ & $7.280^{* * *}$ & $11.87^{* * *}$ & -1.863 & $-17.89^{* * *}$ & $-1.866^{* * *}$ & 4.787 \\
\hline & $(0.0181)$ & $(0.0198)$ & $(1.346)$ & $(1.502)$ & $(2.125)$ & $(2.168)$ & $(0.545)$ & $(7.004)$ \\
\hline & {$[0.0131]$} & {$[0.0143]$} & {$[0.964]$} & {$[1.581]$} & {$[2.324]$} & {$[1.646]$} & {$[0.293]$} & {$[4.985]$} \\
\hline Observations & 931 & 931 & 930 & 930 & 930 & 929 & 927 & 931 \\
\hline \multicolumn{9}{|c|}{ Panel B. With Controls } \\
\hline \multirow[t]{3}{*}{ Equal Division } & $-0.0537^{* * *}$ & $-0.0505^{* * *}$ & $6.835^{* * *}$ & $11.07^{* * *}$ & $-3.830^{*}$ & $-13.36^{* * *}$ & $-1.573^{* * *}$ & 8.756 \\
\hline & $(0.0124)$ & $(0.0126)$ & $(1.019)$ & $(1.546)$ & $(2.104)$ & $(1.691)$ & $(0.269)$ & $(6.618)$ \\
\hline & {$[0.00995]$} & {$[0.0103]$} & {$[0.969]$} & {$[1.589]$} & {$[2.048]$} & {$[1.436]$} & {$[0.240]$} & {$[5.204]$} \\
\hline Observations & 931 & 931 & 930 & 930 & 930 & 929 & 927 & 931 \\
\hline \multicolumn{9}{|c|}{ Panel C. Distance to Border } \\
\hline \multirow[t]{3}{*}{ Equal Division } & $-0.0459^{* * *}$ & $-0.0500^{* * *}$ & $5.798^{* * *}$ & $9.512^{* * *}$ & $-5.046^{* * *}$ & $-10.29^{* * *}$ & $-1.246^{* * *}$ & 5.874 \\
\hline & $(0.00939)$ & $(0.00986)$ & $(1.021)$ & $(1.592)$ & $(1.683)$ & $(1.618)$ & $(0.164)$ & $(5.750)$ \\
\hline & {$[0.00919]$} & {$[0.00891]$} & {$[1.003]$} & {$[1.582]$} & {$[1.855]$} & {$[1.492]$} & {$[0.194]$} & {$[4.917]$} \\
\hline Observations & 397 & 397 & 394 & 394 & 394 & 393 & 391 & 397 \\
\hline \multicolumn{9}{|c|}{ Panel D. Distance to Border $\times$ Equal Division } \\
\hline \multirow[t]{3}{*}{ Equal Division } & $-0.0323^{* * *}$ & $-0.0337^{* * *}$ & $3.287^{* *}$ & $6.445^{* * *}$ & $-4.510^{* *}$ & $-4.355^{* *}$ & $-0.708^{* *}$ & 6.111 \\
\hline & $(0.0119)$ & $(0.0121)$ & $(1.505)$ & $(1.929)$ & $(2.105)$ & $(2.004)$ & $(0.265)$ & $(6.583)$ \\
\hline & {$[0.0111]$} & {$[0.0114]$} & {$[1.220]$} & {$[1.920]$} & {$[2.302]$} & {$[1.583]$} & {$[0.207]$} & {$[6.288]$} \\
\hline Observations & 397 & 397 & 394 & 394 & 394 & 393 & 391 & 397 \\
\hline mean outcome & 0.716 & 0.716 & 8.242 & 13.34 & 33.84 & 27.08 & 5.997 & 127.7 \\
\hline SD outcome & 0.123 & 0.123 & 7.031 & 10.69 & 15.04 & 16.06 & 3.318 & 45.65 \\
\hline
\end{tabular}

Notes: Share of farms in 5 size categories as stated in 'Statistik des Deutschen Reichs' Vol. 109. Panel A includes longitude, latitude, and state-fixed effects. Panel B additionally includes geographic and cultural controls as specified in summary statistics. Panel C reduces the sample to counties in $35 \mathrm{~km}$ distance to the border of the inheritance rule. Independent cities are excluded. Panel D additionally includes an interaction term between distance to the border and treatment allowing the slope to vary on either side of the border. Regressions are weighted by population. Standard errors clustered at the district (Regierungsbezirk) level. Conley standard errors in square brackets. ${ }^{*} \mathrm{p}<0.1,{ }^{* *} \mathrm{p}<0.05$, $* * * \mathrm{p}<0.01$ 
Table 3: Equal Division and Income Measures 2014

\begin{tabular}{|c|c|c|c|c|}
\hline & $\begin{array}{c}(1) \\
\text { Log Household Income }\end{array}$ & $\begin{array}{c}(2) \\
\text { Log Taxable Income }\end{array}$ & $\begin{array}{c}(3) \\
\text { Log Median Income }\end{array}$ & $\begin{array}{c}(4) \\
\log \text { GDP p.c. }\end{array}$ \\
\hline \multicolumn{5}{|l|}{ Panel A. OLS } \\
\hline \multirow[t]{3}{*}{ Equal Division } & $0.0690^{* * *}$ & $0.0726^{* * *}$ & $0.0499^{* *}$ & $0.133^{* *}$ \\
\hline & $(0.0236)$ & $(0.0205)$ & $(0.0186)$ & $(0.0562)$ \\
\hline & {$[0.0174]$} & {$[0.0211]$} & {$[0.0142]$} & {$[0.0324]$} \\
\hline Observations & 397 & 374 & 397 & 397 \\
\hline \multicolumn{5}{|c|}{ Panel B. With Controls } \\
\hline \multirow[t]{3}{*}{ Equal Division } & $0.0617^{* * *}$ & $0.0637^{* * *}$ & $0.0446^{* * *}$ & $0.144^{* * *}$ \\
\hline & $(0.0193)$ & $(0.0195)$ & $(0.0103)$ & $(0.0379)$ \\
\hline & {$[0.0145]$} & {$[0.0177]$} & {$[0.0138]$} & {$[0.0369]$} \\
\hline Observations & 397 & 374 & 397 & 397 \\
\hline \multicolumn{5}{|c|}{ Panel C. Distance to Border } \\
\hline \multirow[t]{3}{*}{ Equal Division } & $0.0572^{* * *}$ & $0.0663^{* * *}$ & $0.0438^{* * *}$ & $0.143^{* * *}$ \\
\hline & $(0.0167)$ & $(0.0168)$ & $(0.00986)$ & $(0.0481)$ \\
\hline & {$[0.0146]$} & {$[0.0179]$} & {$[0.0127]$} & {$[0.0452]$} \\
\hline Observations & 198 & 178 & 198 & 198 \\
\hline \multicolumn{5}{|c|}{ Panel D. Distance to Border $\times$ Equal Division } \\
\hline \multirow[t]{3}{*}{ Equal Division } & $0.0463^{*}$ & $0.0492^{* *}$ & $0.0317^{* *}$ & $0.112^{*}$ \\
\hline & $(0.0242)$ & $(0.0221)$ & $(0.0147)$ & $(0.0573)$ \\
\hline & {$[0.0192]$} & {$[0.0221]$} & {$[0.0134]$} & {$[0.0576]$} \\
\hline Observations & 198 & 178 & 198 & 198 \\
\hline Mean Outcome & 6.719 & 3.461 & 7.956 & 3.447 \\
\hline SD Outcome & 0.115 & 0.146 & 0.162 & 0.336 \\
\hline
\end{tabular}

Notes: The table reports the effect of equal division on the outcomes reported in the column headers. The unit of observation is a county. Data on income and GDP per capita stem from the Federal Statistical Office of Germany and INKAR of 2013/14. Panel A includes longitude, latitude, and state-fixed effects. Panel B additionally includes geographic and cultural controls as specified in summary statistics. Panel $\mathrm{C}$ reduces the sample to counties in $35 \mathrm{~km}$ distance to the border of the inheritance rule. Panel $\mathrm{D}$ additionally includes an interaction term between distance to the border and treatment allowing the slope to vary on either side of the border. Independent cities with more than 100.000 inhabitants are excluded. Regressions are weighted by population. Standard errors clustered at the district (Regierungsbezirk) level. Conley standard errors in square brackets. ${ }^{*} \mathrm{p}<0.1,{ }^{* *} \mathrm{p}<0.05$, $* * * \mathrm{p}<0.01$ 
Table 4: Equal Division and Inequality Measures 2014 and 1995

\begin{tabular}{|c|c|c|c|c|c|c|c|c|}
\hline & $\begin{array}{c}(1) \\
\text { top } 10 \% \text { inc. } \\
\text { share }(\%)\end{array}$ & $\begin{array}{c}(2) \\
\text { top } 1 \% \text { inc. } \\
\text { share }(\%)\end{array}$ & $\begin{array}{c}(3) \\
\log \text { mean } \\
\text { income top } 10 \%\end{array}$ & $\begin{array}{c}(4) \\
\log \text { mean } \\
\text { income top } 1 \%\end{array}$ & $\begin{array}{c}(5) \\
\text { share with } \\
\text { inc. }<10.000 \text { Euro }\end{array}$ & $\begin{array}{c}(6) \\
\text { share with } \\
\text { inc. }<20.000 \text { Euro }\end{array}$ & $\begin{array}{c}(7) \\
\text { Wealth taxpayers } \\
\text { per } 10.000\end{array}$ & $\begin{array}{c}(8) \\
\text { Millionaires } \\
\text { per } 10.000\end{array}$ \\
\hline \multicolumn{9}{|l|}{ Panel A. OLS } \\
\hline \multirow[t]{3}{*}{ Equal Division } & $2.282^{* *}$ & 0.847 & $0.105^{* * *}$ & $0.102^{*}$ & $-1.433^{*}$ & $-1.523^{*}$ & $34.92^{* * *}$ & $6.258^{* * *}$ \\
\hline & $(0.874)$ & $(0.566)$ & $(0.0324)$ & $(0.0580)$ & $(0.809)$ & $(0.769)$ & $(8.454)$ & $(1.990)$ \\
\hline & {$[0.579]$} & {$[0.368]$} & {$[0.0299]$} & {$[0.0401]$} & {$[0.785]$} & {$[0.781]$} & {$[8.863]$} & {$[1.605]$} \\
\hline Observations & 395 & 395 & 395 & 395 & 395 & 395 & 319 & 319 \\
\hline \multicolumn{9}{|c|}{ Panel B. With Controls } \\
\hline \multirow[t]{3}{*}{ Equal Division } & $2.071^{* * *}$ & $1.141^{* *}$ & $0.0954^{* * *}$ & $0.131^{* *}$ & $-1.235^{*}$ & $-1.331^{*}$ & $35.16^{* * *}$ & $7.504^{* * *}$ \\
\hline & $(0.629)$ & $(0.485)$ & $(0.0268)$ & $(0.0514)$ & $(0.705)$ & $(0.682)$ & $(10.55)$ & $(1.945)$ \\
\hline & {$[0.618]$} & {$[0.368]$} & {$[0.0266]$} & {$[0.0391]$} & {$[0.716]$} & {$[0.738]$} & {$[8.482]$} & {$[1.579]$} \\
\hline Observations & 395 & 395 & 395 & 395 & 395 & 395 & 319 & 319 \\
\hline \multicolumn{9}{|c|}{ Panel C. Distance to Border } \\
\hline \multirow[t]{3}{*}{ Equal Division } & $1.656^{* *}$ & $1.158^{* *}$ & $0.0861^{* * *}$ & $0.135^{* * *}$ & $-1.443^{*}$ & $-1.525^{*}$ & $30.97^{* * *}$ & $6.403^{* * *}$ \\
\hline & $(0.751)$ & $(0.541)$ & $(0.0217)$ & $(0.0466)$ & $(0.817)$ & $(0.783)$ & $(10.78)$ & $(1.774)$ \\
\hline & {$[0.789]$} & {$[0.455]$} & {$[0.0258]$} & {$[0.0416]$} & {$[0.803]$} & {$[0.808]$} & {$[10.01]$} & {$[1.870]$} \\
\hline Observations & 196 & 196 & 196 & 196 & 196 & 196 & 172 & 172 \\
\hline \multicolumn{9}{|c|}{ Panel D. Distance to Border $\times$ Equal Division } \\
\hline \multirow[t]{3}{*}{ Equal Division } & $2.102^{*}$ & $1.518^{*}$ & $0.0744^{* *}$ & $0.137^{*}$ & -0.422 & -0.610 & $16.21^{*}$ & $4.466^{* *}$ \\
\hline & $(1.030)$ & $(0.758)$ & $(0.0308)$ & $(0.0670)$ & $(1.205)$ & $(1.115)$ & $(9.154)$ & $(2.141)$ \\
\hline & {$[0.920]$} & {$[0.596]$} & {$[0.0298]$} & {$[0.0528]$} & {$[0.954]$} & {$[0.971]$} & {$[10.89]$} & {$[2.473]$} \\
\hline Observations & 196 & 196 & 196 & 196 & 196 & 196 & 172 & 172 \\
\hline Mean Outcome & 37.37 & 10.98 & 11.69 & 12.76 & 36.71 & 50.90 & 150.4 & 22.14 \\
\hline SD Outcome & 5.034 & 2.613 & 0.224 & 0.306 & 7.239 & 8.051 & 54.17 & 10.12 \\
\hline
\end{tabular}

Notes: The table reports the effect of equal division on the outcomes reported in the column headers. The unit of observation is a county. Income inequality measures calculated from 2014 income tax statistics, national accounts and population statistics of the Federal Statistical Office of Germany. Income bins are available with aggregate income per bin a and nut latitude, and state-fixed effects. Panel B additionally includes geographic and cultural controls as specified in summary statistics. Panel $\mathrm{C}$ reduces the sample to counties in 35 $\mathrm{km}$ distance to the border of the inheritance rule. Panel D additionally includes an interaction term between distance to the border and treatment allowing the slope to vary on either side of the border. Independent cities with more than 100.000 inhabitants are excluded. Regressions are weighted by population. Standard errors clustered at the distric (Regierungsbezirk) level. Conley standard errors in square brackets. ${ }^{*} \mathrm{p}<0.1,{ }^{* *} \mathrm{p}<0.05,{ }^{* * *} \mathrm{p}<0.01$ 
Table 5: Equal Division and Education, Industry Structure and Productivity 2014

\begin{tabular}{|c|c|c|c|c|c|c|c|c|c|}
\hline & \multicolumn{2}{|c|}{ Education } & \multicolumn{5}{|c|}{ Employment } & \multicolumn{2}{|c|}{ Firms } \\
\hline & $\begin{array}{c}(1) \\
\text { College Degree }\end{array}$ & $\begin{array}{c}(2) \\
\text { Vocational Training }\end{array}$ & $\begin{array}{c}(3) \\
\text { Agric. }\end{array}$ & $\begin{array}{c}(4) \\
\text { Manuf. }\end{array}$ & $\begin{array}{c}(5) \\
\text { Trade and Services }\end{array}$ & $\begin{array}{c}(6) \\
\text { Creative Ind. }\end{array}$ & $\begin{array}{c}(7) \\
\text { Lab. prod. }\end{array}$ & $\begin{array}{c}(8) \\
\text { Per Pop }\end{array}$ & $\begin{array}{l}(9) \\
\text { Size }\end{array}$ \\
\hline \multicolumn{10}{|l|}{ Panel A. OLS } \\
\hline Equal Division & $\begin{array}{c}3.343^{* * *} \\
(0.734) \\
{[0.734]} \\
397\end{array}$ & $\begin{array}{c}-3.819^{* * *} \\
(0.940) \\
{[0.851]} \\
397\end{array}$ & $\begin{array}{c}-0.259^{* * *} \\
(0.0913) \\
{[0.0850]} \\
397\end{array}$ & $\begin{array}{c}-4.613^{* * *} \\
(1.365) \\
{[1.473]} \\
397\end{array}$ & $\begin{array}{c}4.882^{* * *} \\
(1.381) \\
{[1.495]} \\
397\end{array}$ & $\begin{array}{c}1.266^{* * *} \\
(0.343) \\
{[0.286]} \\
397\end{array}$ & $\begin{array}{c}5.149^{* * *} \\
(1.345) \\
{[1.131]} \\
395\end{array}$ & $\begin{array}{c}0.00127^{*} \\
(0.000715) \\
{[0.000514]} \\
380\end{array}$ & $\begin{array}{c}-0.387 \\
(0.387) \\
{[0.300]} \\
380\end{array}$ \\
\hline \multicolumn{10}{|c|}{ Panel B. With Controls } \\
\hline Equal Division & $\begin{array}{c}2.789^{* * *} \\
(0.696) \\
{[0.788]} \\
397\end{array}$ & $\begin{array}{c}-2.759^{* * *} \\
(0.608) \\
{[0.695]} \\
397\end{array}$ & $\begin{array}{c}-0.397^{* *} \\
(0.155) \\
{[0.123]} \\
397\end{array}$ & $\begin{array}{c}-2.902^{*} \\
(1.608) \\
{[1.528]} \\
397\end{array}$ & $\begin{array}{c}3.300^{*} \\
(1.630) \\
{[1.540]} \\
397\end{array}$ & $\begin{array}{c}1.187^{* * *} \\
(0.357) \\
{[0.304]} \\
397\end{array}$ & $\begin{array}{c}3.698^{* * *} \\
(1.084) \\
{[0.970]} \\
395\end{array}$ & $\begin{array}{c}0.00205^{* * *} \\
(0.000594) \\
{[0.000615]} \\
380\end{array}$ & $\begin{array}{c}-0.907^{* *} \\
(0.401) \\
{[0.366]} \\
380\end{array}$ \\
\hline \multicolumn{10}{|c|}{ Panel C. Distance to Border } \\
\hline Equal Division & $\begin{array}{c}2.388^{* * *} \\
(0.729) \\
{[0.789]} \\
198\end{array}$ & $\begin{array}{c}-2.371^{* * *} \\
(0.634) \\
{[0.658]} \\
198\end{array}$ & $\begin{array}{c}-0.326^{* * *} \\
(0.104) \\
{[0.154]} \\
198\end{array}$ & $\begin{array}{c}-1.539 \\
(1.970) \\
{[1.962]} \\
198\end{array}$ & $\begin{array}{c}1.870 \\
(1.976) \\
{[2.024]} \\
198\end{array}$ & $\begin{array}{c}1.088^{* * *} \\
(0.388) \\
{[0.349]} \\
198\end{array}$ & $\begin{array}{c}3.317^{* * *} \\
(1.131) \\
{[0.888]} \\
196\end{array}$ & $\begin{array}{c}0.00195^{* * *} \\
(0.000612) \\
{[0.000673]} \\
183\end{array}$ & $\begin{array}{c}-0.706^{*} \\
(0.385) \\
{[0.406]} \\
183\end{array}$ \\
\hline \multicolumn{10}{|c|}{ Panel D. Distance to Border $\times$ Equal Division } \\
\hline Equal Division & $\begin{array}{c}1.866^{*} \\
(1.087) \\
{[0.829]} \\
198\end{array}$ & $\begin{array}{c}-1.183 \\
(0.885) \\
{[0.772]} \\
198\end{array}$ & $\begin{array}{c}-0.328^{* *} \\
(0.139) \\
{[0.187]} \\
198\end{array}$ & $\begin{array}{c}-0.0733 \\
(2.220) \\
{[2.185]} \\
198\end{array}$ & $\begin{array}{c}0.433 \\
(2.259) \\
{[2.261]} \\
198\end{array}$ & $\begin{array}{c}0.934^{*} \\
(0.456) \\
{[0.411]} \\
198\end{array}$ & $\begin{array}{c}1.744 \\
(1.414) \\
{[1.029]} \\
196\end{array}$ & $\begin{array}{c}0.00148^{*} \\
(0.000819) \\
{[0.000806]} \\
183\end{array}$ & $\begin{array}{c}-0.550 \\
(0.485) \\
{[0.494]} \\
183\end{array}$ \\
\hline $\begin{array}{l}\text { Mean Outcome } \\
\text { SD Outcome }\end{array}$ & $\begin{array}{l}11.19 \\
4.873\end{array}$ & $\begin{array}{l}64.51 \\
6.396\end{array}$ & $\begin{array}{l}1.052 \\
1.260\end{array}$ & $\begin{array}{l}32.40 \\
10.49\end{array}$ & $\begin{array}{l}66.55 \\
10.66\end{array}$ & $\begin{array}{l}2.645 \\
2.090\end{array}$ & $\begin{array}{l}47.22 \\
8.504\end{array}$ & $\begin{array}{c}0.0261 \\
0.00355\end{array}$ & $\begin{array}{l}14.41 \\
1.983\end{array}$ \\
\hline
\end{tabular}

Notes: The table reports the effect of equal division on the outcomes reported in the column headers. The unit of observation is a county. Data on education and industry structure stem from INKAR data of 2013/14. Labor productivity is measured as GDP per working hour and stems from National Accounts of the Laender (www.vgrdl.de). Panel A includes longitude, latitude, and state-fixed effects. Panel B additionally includes geographic and cultural controls as specified in summary statistics. Panel C reduces the sample to counties in $35 \mathrm{~km}$ distance to the border of the inheritance rule. Panel D additionally includes an interaction term between distance to the border and treatment allowing the slope to vary on either side of the border. Independent cities with more than 100.000 inhabitants are excluded. Regressions are weighted by population. Standard errors clustered at the district (Regierungsbezirk) level. Conley standard errors in square brackets. ${ }^{*} \mathrm{p}<0.1,{ }^{* *} \mathrm{p}<0.05,{ }^{* * *} \mathrm{p}<0.01$ 
Table 6: Equal Division and Agricultural Productivity

\begin{tabular}{lcc}
\hline & $(1)$ & $(2)$ \\
& $\begin{array}{c}\text { Mean Caloric Output } \\
\text { Pre } 1500\end{array}$ & $\begin{array}{c}\text { Prussia: Grain } \\
\text { Yields kg/ha }\end{array}$ \\
\hline Panel A. OLS & $68.12^{* * *}$ & -3.112 \\
Equal Division & $(25.39)$ & $(7.277)$ \\
Observations & 935 & 415 \\
\hline Panel B. With Controls & 3.323 & \\
Equal Division & $(16.63)$ & -3.392 \\
Observations & 935 & $415.004)$ \\
\hline Panel C. Distance to Border & 10.50 & -2.065 \\
Equal Division & $(9.863)$ & $(4.951)$ \\
Observations & 396 & 190 \\
\hline Mean Outcome & 2211.4 & 74.77 \\
SD Outcome & 152.1 & 24.44 \\
\hline
\end{tabular}

The table uses in column 1 an index of caloric output per hectare per year before the year 1500 as outcome variable which is constructed by Galor \& Özak (2016). In column 1 we use the whole sample of the German Empire in 1895. In column 2 grain yields in kilogram per hectare from Prussia in 1878 is the outcome variable. The sample is reduced to the 415 Prussian counties. Panel A includes longitude, latitude, and state-fixed effects. Panel B additionally includes geographic and cultural controls as specified in summary statistics. Panel C reduces the sample to counties in $35 \mathrm{~km}$ distance to the border of the inheritance rule. Regressions are weighted by population. Standard errors clustered at the district (Regierungsbezirk) level. ${ }^{*} \mathrm{p}<0.1,{ }^{* *} \mathrm{p}<0.05$, $* * * \mathrm{p}<0.01$ 
Table 7: Equal Division and Population Density

\begin{tabular}{|c|c|c|c|c|}
\hline & \multicolumn{4}{|c|}{ Population Density } \\
\hline & $\begin{array}{c}(1) \\
\text { Prussia } 1816\end{array}$ & $\begin{array}{c}(2) \\
1895\end{array}$ & $\begin{array}{c}(3) \\
1907\end{array}$ & $\begin{array}{c}(4) \\
\text { DID }\end{array}$ \\
\hline \multicolumn{5}{|l|}{ Panel A. OLS } \\
\hline Equal Division & $\begin{array}{c}1.507 \\
(9.257)\end{array}$ & $\begin{array}{c}63.73 \\
(88.75)\end{array}$ & $\begin{array}{c}117.5 \\
(115.1)\end{array}$ & $\begin{array}{c}75.86 \\
(95.07)\end{array}$ \\
\hline Equal Division x 1907 & & & & $\begin{array}{c}31.33 \\
(22.75)\end{array}$ \\
\hline Observations & 318 & 937 & 948 & 1885 \\
\hline \multicolumn{5}{|l|}{ Panel B. With Controls } \\
\hline Equal Division & $\begin{array}{c}-14.65^{* *} \\
(6.754)\end{array}$ & $\begin{array}{c}76.68 \\
(58.79)\end{array}$ & $\begin{array}{c}131.9^{*} \\
(70.90)\end{array}$ & $\begin{array}{c}91.42 \\
(58.54)\end{array}$ \\
\hline Equal Division x 1907 & & & & $\begin{array}{c}28.08 \\
(21.03)\end{array}$ \\
\hline Observations & 318 & 937 & 948 & 1885 \\
\hline \multicolumn{5}{|c|}{ Panel C. Distance to Border } \\
\hline Equal Division & $\begin{array}{c}2.608 \\
(4.080)\end{array}$ & $\begin{array}{c}55.48 \\
(44.05)\end{array}$ & $\begin{array}{l}101.8^{*} \\
(51.91)\end{array}$ & $\begin{array}{c}56.08 \\
(42.45)\end{array}$ \\
\hline Equal Division x 1907 & & & & $\begin{array}{l}47.76^{* *} \\
(20.85)\end{array}$ \\
\hline Observations & 95 & 398 & 406 & 804 \\
\hline Mean Outcome & 58.80 & 169.2 & 220.5 & 196.3 \\
\hline SD Outcome & 35.89 & 283.9 & 369.3 & 332.6 \\
\hline
\end{tabular}

Notes: The table reports the effect of equal division on the outcomes reported in the column headers. The unit of observation is a county. The tables uses population density as outcome measure. In column 1 the sample stems from Prussian counties in 1816. In column 2 and 3 from the whole sample of the German Empire in 1895 and 1907, respectively. Column 4 shows a DID approach estimating the change in population density in rural German counties between 1895 and 1907. Panel A includes longitude, latitude, and state-fixed effects. Panel B additionally includes geographic and cultural controls as specified in summary statistics. Panel C reduces the sample to counties in $35 \mathrm{~km}$ distance to the border of the inheritance rule. Regressions are weighted by population. Standard errors clustered at the district (Regierungsbezirk) level. ${ }^{*} \mathrm{p}<0.1,{ }^{* *} \mathrm{p}<0.05,{ }^{* * *} \mathrm{p}<0.01$ 
Table 8: Equal Division and Technological Progress 1821 - 1882

\begin{tabular}{|c|c|c|c|c|c|}
\hline & \multicolumn{3}{|c|}{ Technological Progress 1821} & \multicolumn{2}{|c|}{ Employment 1882} \\
\hline & $\begin{array}{c}(1) \\
\text { Factories } \\
\text { (per }\end{array}$ & $\begin{array}{c}(2) \\
\text { Mills } \\
1000 \text { Peo }\end{array}$ & $\begin{array}{l}(3) \\
\text { Looms } \\
\text { le) }\end{array}$ & $\begin{array}{c}(4) \\
\text { Self Empl. } \\
\text { out of Agric. }\end{array}$ & $\begin{array}{c}(5) \\
\text { Manuf. }\end{array}$ \\
\hline \multicolumn{6}{|l|}{ Panel A. OLS } \\
\hline Equal Division & $\begin{array}{c}-0.0895 \\
(0.0878)\end{array}$ & $\begin{array}{c}0.105 \\
(0.286)\end{array}$ & $\begin{array}{c}-5.217^{*} \\
(2.926)\end{array}$ & $\begin{array}{c}-0.143 \\
(0.553)\end{array}$ & $\begin{array}{c}-1.237 \\
(1.626)\end{array}$ \\
\hline Observations & 318 & 318 & 318 & 415 & 415 \\
\hline \multicolumn{6}{|c|}{ Panel B. With Controls } \\
\hline Equal Division & $\begin{array}{c}0.00689 \\
(0.0731)\end{array}$ & $\begin{array}{c}0.231 \\
(0.320)\end{array}$ & $\begin{array}{c}-7.419^{*} \\
(4.044)\end{array}$ & $\begin{array}{c}-0.640 \\
(0.728)\end{array}$ & $\begin{array}{c}0.237 \\
(1.675)\end{array}$ \\
\hline Observations & 318 & 318 & 318 & 415 & 415 \\
\hline \multicolumn{6}{|c|}{ Panel C. Distance to Border } \\
\hline Equal Division & $\begin{array}{c}-0.0703^{*} \\
(0.0329)\end{array}$ & $\begin{array}{c}-0.207 \\
(0.185)\end{array}$ & $\begin{array}{l}-0.633 \\
(4.690)\end{array}$ & $\begin{array}{c}0.0254 \\
(0.532)\end{array}$ & $\begin{array}{c}0.778 \\
(1.353)\end{array}$ \\
\hline Observations & 95 & 95 & 95 & 190 & 190 \\
\hline Mean Outcome & 0.254 & 1.111 & 5.492 & 5.557 & 8.227 \\
\hline SD Outcome & 0.238 & 0.986 & 12.83 & 2.385 & 5.591 \\
\hline
\end{tabular}

Notes: The table reports the effect of equal division on the outcomes reported in the column headers. The unit of observation is a county. The tables uses a sample of Prussian counties in 1821 and in 1882 with different proxies for technological progress. Column 1 uses factories column 2 mills and column 3 looms per 1000 people as outcome variable. In column 4 self-employed people out of agriculture as percent of total population is the outcome variable. In column 5 percent of population in the manufacturing sector is the outcome variable. Panel A includes longitude, latitude, and state-fixed effects. Panel B additionally includes geographic and cultural controls as specified in summary statistics. Panel C reduces the sample to counties in $35 \mathrm{~km}$ distance to the border of the inheritance rule. Regressions are weighted by population. Standard errors clustered at the district (Regierungsbezirk) level. ${ }^{*} \mathrm{p}<0.1,{ }^{* *} \mathrm{p}<0.05,{ }^{* * *} \mathrm{p}<0.01$ 
Table 9: Equal Division and Sectoral Employment 1895 and 1907

\begin{tabular}{|c|c|c|c|c|c|c|}
\hline & \multicolumn{3}{|c|}{ Employment 1895} & \multicolumn{3}{|c|}{ Employment 1907} \\
\hline & $(1)$ & $(2)$ & $(3)$ & $(4)$ & $(5)$ & $(6)$ \\
\hline & Agric. & Manuf. & Trade and Services & Agric. & Manuf. & Trade and Services \\
\hline \multicolumn{7}{|l|}{ Panel A. OLS } \\
\hline \multirow[t]{3}{*}{ Equal Division } & -2.489 & 0.304 & 0.165 & -3.998 & 1.130 & 0.277 \\
\hline & $(2.085)$ & $(1.427)$ & $(0.174)$ & $(2.729)$ & $(1.507)$ & $(0.214)$ \\
\hline & {$[1.354]$} & {$[0.917]$} & {$[0.152]$} & {$[1.807]$} & {$[0.973]$} & {$[0.179]$} \\
\hline Observations & 889 & 889 & 889 & 900 & 900 & 900 \\
\hline \multicolumn{7}{|c|}{ Panel B. With Controls } \\
\hline \multirow[t]{3}{*}{ Equal Division } & $-2.578^{*}$ & 1.040 & $0.220^{*}$ & $-4.104^{* *}$ & $2.253^{* *}$ & $0.309^{*}$ \\
\hline & $(1.296)$ & $(1.036)$ & $(0.130)$ & $(1.694)$ & $(1.067)$ & $(0.184)$ \\
\hline & {$[1.256]$} & {$[0.881]$} & {$[0.130]$} & {$[1.585]$} & {$[0.907]$} & {$[0.153]$} \\
\hline Observations & 886 & 886 & 886 & 897 & 897 & 897 \\
\hline \multicolumn{7}{|c|}{ Panel C. Distance to Border } \\
\hline \multirow[t]{3}{*}{ Equal Division } & $-2.109^{* *}$ & $1.577^{* *}$ & $0.273^{* *}$ & $-3.832^{* * *}$ & $2.624^{* * *}$ & $0.312^{* *}$ \\
\hline & $(1.001)$ & $(0.767)$ & $(0.120)$ & $(1.308)$ & $(0.810)$ & $(0.154)$ \\
\hline & {$[1.046]$} & {$[0.730]$} & {$[0.135]$} & [1.395] & {$[0.804]$} & {$[0.154]$} \\
\hline Observations & 382 & 382 & 382 & 390 & 390 & 390 \\
\hline \multicolumn{7}{|c|}{ Panel D. Distance to Border $\times$ Equal Division } \\
\hline \multirow[t]{3}{*}{ Equal Division } & -1.729 & $2.031^{*}$ & 0.111 & $-3.503^{*}$ & $3.434^{* * *}$ & 0.00949 \\
\hline & $(1.223)$ & $(1.079)$ & $(0.193)$ & $(1.759)$ & $(1.256)$ & $(0.289)$ \\
\hline & {$[1.292]$} & {$[0.927]$} & {$[0.219]$} & {$[1.730]$} & {$[1.073]$} & {$[0.262]$} \\
\hline Observations & 382 & 382 & 382 & 390 & 390 & 390 \\
\hline Mean Outcome & 19.190 & 14.560 & 3.428 & 20.359 & 16.471 & 4.208 \\
\hline SD Outcome & 8.941 & 6.783 & 2.174 & 11.893 & 7.376 & 2.721 \\
\hline
\end{tabular}

Notes: The table reports the effect of equal division on the outcomes reported in the column headers. The unit of observation is a county. Employment in sectors and occupations as stated in 'Statistik des Deutschen Reichs' Vol. 109 for 1895 and 209 for 1907 as percent of total population in each district. Panel A includes longitude, latitude, and state-fixed effects. Panel B additionally includes geographic and cultural controls as specified in sumbary statistics. Panel $\mathrm{C}$ reduces the sample to counties in 35 km distance to the border f the Pan B addite

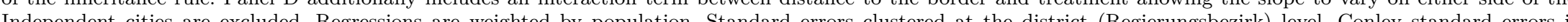
brackets. ${ }^{*} \mathrm{p}<0.1,{ }^{* *} \mathrm{p}<0.05,{ }^{* * *} \mathrm{p}<0.01$ 
Table 10: Equal Division and Innovation and Entrepreneurship I: Employment in Innovative Manufacturing

\begin{tabular}{|c|c|c|c|c|c|c|}
\hline \multirow{2}{*}{ Panel A. OLS } & \multicolumn{3}{|c|}{ in $\%$ of Total Pop. } & \multicolumn{2}{|c|}{ in $\%$ of Manufacturing Pop. } & $\begin{array}{l}\text { ing Pop. } \\
\quad(6)\end{array}$ \\
\hline & & & & & & \\
\hline Equal Division & $\begin{array}{l}2.125^{* *} \\
(0.938) \\
{[0.854]}\end{array}$ & $\begin{array}{l}-1.004 \\
(1.372) \\
{[1.180]}\end{array}$ & $\begin{array}{c}4.783^{* * *} \\
(1.533) \\
{[1.657]}\end{array}$ & $\begin{array}{l}3.048^{* *} \\
(1.383) \\
{[1.269]}\end{array}$ & $\begin{array}{l}-0.904 \\
(1.772) \\
{[1.759]}\end{array}$ & $\begin{array}{c}7.180^{* * *} \\
(2.512) \\
{[2.600]}\end{array}$ \\
\hline Equal Division $\times$ Low Soil Quality & & $\begin{array}{c}8.249^{* * *} \\
(2.276) \\
{[2.380]}\end{array}$ & & & $\begin{array}{c}11.11^{* * *} \\
(3.264) \\
{[3.161]}\end{array}$ & \\
\hline Equal Division $\times$ Farm Size & & & $\begin{array}{c}-1.261^{* * *} \\
(0.321) \\
{[0.306]}\end{array}$ & & & $\begin{array}{c}-1.411^{* * *} \\
(0.522) \\
{[0.491]}\end{array}$ \\
\hline Observations & 900 & 900 & 896 & 900 & 900 & 896 \\
\hline \multicolumn{7}{|l|}{ Panel B. With Controls } \\
\hline Equal Division & $\begin{array}{c}2.358^{* * *} \\
(0.766) \\
{[0.794]}\end{array}$ & $\begin{array}{l}-0.451 \\
(1.119) \\
{[1.096]}\end{array}$ & $\begin{array}{c}5.441^{* * *} \\
(1.569) \\
{[1.626]}\end{array}$ & $\begin{array}{l}3.299^{* *} \\
(1.368) \\
{[1.282]}\end{array}$ & $\begin{array}{l}-0.629 \\
(1.785) \\
{[1.722]}\end{array}$ & $\begin{array}{c}7.627^{* * *} \\
(2.717) \\
{[2.597]}\end{array}$ \\
\hline Equal Division $\times$ Low Soil Quality & & $\begin{array}{l}7.787^{* * *} \\
(2.157) \\
{[2.056]}\end{array}$ & & & $\begin{array}{c}10.89^{* * *} \\
(3.307) \\
{[2.897]}\end{array}$ & \\
\hline Equal Division $\times$ Farm Size & & & $\begin{array}{c}-1.215^{* * *} \\
(0.367) \\
{[0.312]}\end{array}$ & & & $\begin{array}{c}-1.302^{* *} \\
(0.583) \\
{[0.485]}\end{array}$ \\
\hline Observations & 897 & 897 & 893 & 897 & 897 & 893 \\
\hline \multicolumn{7}{|l|}{ Panel C. Distance to Border } \\
\hline Equal Division & $\begin{array}{c}2.493^{* * *} \\
(0.843) \\
{[0.797]}\end{array}$ & $\begin{array}{l}-0.874 \\
(1.273) \\
{[1.247]}\end{array}$ & $\begin{array}{l}3.933^{* *} \\
(1.624) \\
{[2.088]}\end{array}$ & $\begin{array}{l}3.207^{* *} \\
(1.461) \\
{[1.353]}\end{array}$ & $\begin{array}{l}-2.030 \\
(2.117) \\
{[2.058]}\end{array}$ & $\begin{array}{c}4.699 \\
(3.039) \\
{[3.375]}\end{array}$ \\
\hline Equal Division $\times$ Low Soil Quality & & $\begin{array}{c}9.186^{* * *} \\
(2.658) \\
{[2.399]}\end{array}$ & & & $\begin{array}{l}14.29^{* * *} \\
(4.242) \\
{[3.713]}\end{array}$ & \\
\hline Equal Division $\times$ Farm Size & & & $\begin{array}{c}-0.849^{* *} \\
(0.392) \\
{[0.428]}\end{array}$ & & & $\begin{array}{l}-0.746 \\
(0.602) \\
{[0.673]}\end{array}$ \\
\hline Observations & 390 & 390 & 388 & 390 & 390 & 388 \\
\hline \multicolumn{7}{|c|}{ Panel D. Distance to Border $\times$ Equal Division } \\
\hline Equal Division & $\begin{array}{l}2.201^{*} \\
(1.260) \\
{[1.075]}\end{array}$ & $\begin{array}{c}-0.885 \\
(1.408) \\
{[1.429]}\end{array}$ & $\begin{array}{c}3.789^{*} \\
(1.954) \\
{[2.060]}\end{array}$ & $\begin{array}{c}1.690 \\
(2.206) \\
{[1.884]}\end{array}$ & $\begin{array}{l}-3.045 \\
(2.508) \\
{[2.511]}\end{array}$ & $\begin{array}{c}3.381 \\
(3.612) \\
{[3.611]}\end{array}$ \\
\hline Equal Division $\times$ Low Soil Quality & & $\begin{array}{c}9.184^{* * *} \\
(2.718) \\
{[2.392]}\end{array}$ & & & $\begin{array}{c}14.09^{* * *} \\
(4.276) \\
{[3.693]}\end{array}$ & \\
\hline Equal Division $\times$ Farm Size & & & $\begin{array}{c}-0.852^{* *} \\
(0.392) \\
{[0.427]}\end{array}$ & & & $\begin{array}{l}-0.774 \\
(0.617) \\
{[0.677]}\end{array}$ \\
\hline Observations & 390 & 390 & 388 & 390 & 390 & 388 \\
\hline Mean Outcome & 6.874 & 6.874 & 6.865 & 16.177 & 16.177 & 16.168 \\
\hline SD Outcome & 5.664 & 5.664 & 5.666 & 8.639 & 8.639 & 8.645 \\
\hline
\end{tabular}

Notes: The table reports the effect of equal division on the outcomes reported in the column headers. The unit of observation is a county. Soil quality is measured by the share of loam, sand and silt. Panel A includes longitude, latitude, and state-fixed effects. Panel B additionally includes geographic and cultural controls as specified in summary statistics. Panel C reduces the sample to counties in $35 \mathrm{~km}$ distance to the border of the inheritance rule. Panel D additionally includes an interaction term between distance to the border and treatment allowing the slope to vary on either side of the border. Independent cities are excluded. Regressions are weighted by population in 1907. Standard errors clustered at the district (Regierungsbezirk) level. Conley standard errors in square brackets. ${ }^{*} \mathrm{p}<0.1,{ }^{* *} \mathrm{p}<0.05,{ }^{* * *} \mathrm{p}<0.01$ 
Table 11: Equal Division and Innovation and Entrepreneurship II: Patents 1877 to 1914

\begin{tabular}{|c|c|c|c|c|c|c|}
\hline & \multicolumn{2}{|c|}{ Dummy } & \multicolumn{2}{|c|}{ Log Patents } & \multicolumn{2}{|c|}{ Log Patents w/ Zero } \\
\hline & (1) & $(2)$ & $(3)$ & $(4)$ & $(5)$ & (6) \\
\hline \multicolumn{7}{|l|}{ Panel A. OLS } \\
\hline \multirow[t]{3}{*}{ Equal Division } & 0.0837 & 0.142 & $0.646^{* * *}$ & 0.329 & $0.739^{* *}$ & 0.671 \\
\hline & $(0.0744)$ & $(0.132)$ & $(0.231)$ & $(0.366)$ & $(0.317)$ & $(0.494)$ \\
\hline & {$[0.0591]$} & {$[0.0786]$} & {$[0.189]$} & {$[0.297]$} & {$[0.221]$} & {$[0.294]$} \\
\hline \multirow[t]{3}{*}{ Equal Division x Low Soil Quality } & & -0.0997 & & 0.873 & & 0.393 \\
\hline & & $(0.229)$ & & $(0.604)$ & & $(0.838)$ \\
\hline & & {$[0.167]$} & & {$[0.507]$} & & {$[0.661]$} \\
\hline Observations & 899 & 899 & 499 & 499 & 899 & 899 \\
\hline \multicolumn{7}{|l|}{ Panel B. With Controls } \\
\hline \multirow[t]{2}{*}{ Equal Division } & 0.138 & 0.167 & $0.561^{* *}$ & 0.318 & $0.888^{* *}$ & $0.910^{*}$ \\
\hline & $(0.0837)$ & $(0.116)$ & $(0.226)$ & $(0.355)$ & $(0.344)$ & $(0.511)$ \\
\hline & {$[0.0553]$} & {$[0.0636]$} & {$[0.193]$} & {$[0.278]$} & {$[0.196]$} & {$[0.255]$} \\
\hline \multirow[t]{3}{*}{ Equal Division x Low Soil Quality } & & -0.0841 & & 0.680 & & -0.0627 \\
\hline & & $(0.169)$ & & $(0.600)$ & & $(0.793)$ \\
\hline & & {$[0.128]$} & & {$[0.398]$} & & {$[0.499]$} \\
\hline Observations & 899 & 899 & 499 & 499 & 899 & 899 \\
\hline \multicolumn{7}{|l|}{ Panel C. Distance to Border } \\
\hline \multirow[t]{2}{*}{ Equal Division } & $0.105^{*}$ & 0.00365 & $0.472^{* *}$ & -0.00934 & $0.623^{* *}$ & 0.0495 \\
\hline & $(0.0582)$ & $(0.0748)$ & $(0.224)$ & $(0.254)$ & $(0.246)$ & $(0.298)$ \\
\hline & {$[0.0533]$} & {$[0.0640]$} & {$[0.165]$} & {$[0.264]$} & {$[0.163]$} & {$[0.239]$} \\
\hline \multirow[t]{3}{*}{ Equal Division x Low Soil Quality } & & $0.275^{* *}$ & & $1.337^{* *}$ & & $1.566^{* *}$ \\
\hline & & $(0.134)$ & & $(0.558)$ & & $(0.587)$ \\
\hline & & {$[0.134]$} & & {$[0.347]$} & & {$[0.512]$} \\
\hline Observations & 390 & 390 & 228 & 228 & 390 & 390 \\
\hline \multicolumn{7}{|c|}{ Distance to Border $\times$ Equal Division } \\
\hline \multirow[t]{3}{*}{ Equal Division } & $0.168^{*}$ & 0.0714 & 0.529 & 0.102 & $0.644^{*}$ & 0.114 \\
\hline & $(0.0938)$ & $(0.103)$ & $(0.348)$ & $(0.352)$ & $(0.358)$ & $(0.385)$ \\
\hline & {$[0.0686]$} & {$[0.0780]$} & [0.249] & {$[0.300]$} & {$[0.205]$} & {$[0.255]$} \\
\hline \multirow[t]{3}{*}{ Equal Division x Low Soil Quality } & & $0.288^{* *}$ & & $1.376^{* *}$ & & $1.578^{* *}$ \\
\hline & & $(0.133)$ & & $(0.582)$ & & $(0.595)$ \\
\hline & & {$[0.134]$} & & {$[0.357]$} & & {$[0.513]$} \\
\hline Observations & 390 & 390 & 228 & 228 & 390 & 390 \\
\hline Mean Outcome & 0.669 & 0.669 & 1.979 & 1.979 & 1.994 & 1.994 \\
\hline SD Outcome & 0.471 & 0.471 & 1.542 & 1.542 & 1.886 & 1.886 \\
\hline
\end{tabular}

Notes: The table reports the effect of equal division on the outcomes reported in the column headers. The unit of observation is a county. The outcome in columns 1 and 2 is an indicator which is 1 if a patent was filed in a county between 1877 and 1914 and 0 otherwise. The outcome in columns 3 and 4 is the $\log$ of the number of patents filed in a county between 1877 and 1914 turning all 0 to missings. The outcome in columns 5 and 6 is 0 if no patent was filed in county between 1877 and 1914 and the $\log$ of the number of patents +1 otherwise. Soil quality is measured by the share of loam, sand and silt. Panel A includes longitude, latitude, and state-fixed effects. Panel B additionally includes geographic and cultural controls as specified in summary statistics. Panel C reduces the sample to counties in $35 \mathrm{~km}$ distance to the border of the inheritance rule. Panel D additionally includes an interaction term between distance to the border and treatment allowing the slope to vary on either side of the border. Independent cities are excluded. Regressions are weighted by population in 1907. Standard errors clustered at the district (Regierungsbezirk) level. Conley standard errors in square brackets. ${ }^{*} \mathrm{p}<0.1,{ }^{* *} \mathrm{p}<0.05,{ }^{* * *} \mathrm{p}<0.01$ 
Additional Figures and Tables 
Table A1: Overview of Main Historical Outcome Variables

\begin{tabular}{|c|c|c|c|c|c|c|}
\hline Outcome & & mean (sd) & $\min$ & $\max$ & Explanation & Source \\
\hline \multirow[t]{10}{*}{$\begin{array}{l}\text { income } \\
\text { inequality }\end{array}$} & top $10 \%$ income share 1895 & $\begin{array}{c}30.3 \\
5.6\end{array}$ & 17.4 & 48.4 & $\begin{array}{l}\text { Pareto interpolation using } \\
\text { income tax tabulations and wages }\end{array}$ & statistical offices of Baden and Hesse \\
\hline & top $1 \%$ income share 1895 & $\begin{array}{l}8.9 \\
3.3\end{array}$ & 5.0 & 21.4 & $\begin{array}{l}\text { Pareto interpolation using } \\
\text { income tax tabulations and wages }\end{array}$ & statistical offices of Baden and Hesse \\
\hline & ratio $1 / 901895$ & $\begin{array}{c}13.3 \\
6.6\end{array}$ & 6.0 & 41.6 & top $1 \%$ share/(100-top $10 \%$ share $)$ & statistical offices of Baden and Hesse \\
\hline & log mean income 1895 & $\begin{array}{c}6.8 \\
0.14\end{array}$ & 6.5 & 7.3 & & statistical offices of Baden and Hesse \\
\hline & mean income 1895 & $\begin{array}{l}900 \\
144\end{array}$ & 681 & 1504 & total income/total population & statistical offices of Baden and Hesse \\
\hline & top $10 \%$ income share 1907 & $\begin{array}{c}36.8 \\
8.0\end{array}$ & 21.6 & 52.4 & $\begin{array}{l}\text { Pareto interpolation using } \\
\text { income tax tabulations and wages }\end{array}$ & $\begin{array}{l}\text { statistical offices of Baden, } \\
\text { Hesse and Wuerttemberg }\end{array}$ \\
\hline & top $1 \%$ income share 1907 & $\begin{array}{c}11.0 \\
3.3\end{array}$ & 4.8 & 20.4 & $\begin{array}{l}\text { Pareto interpolation using } \\
\text { income tax tabulations and wages }\end{array}$ & $\begin{array}{l}\text { statistical offices of Baden, } \\
\text { Hesse and Wuerttemberg }\end{array}$ \\
\hline & ratio $1 / 901907$ & $\begin{array}{c}18.2 \\
7.0\end{array}$ & 6.3 & 38.6 & top $1 \%$ share/(100-top $10 \%$ share $)$ & \\
\hline & log mean income 1907 & $\begin{array}{c}6.8 \\
0.25\end{array}$ & 6.5 & 7.5 & & $\begin{array}{l}\text { statistical offices of Baden, } \\
\text { Hesse and Wuerttemberg }\end{array}$ \\
\hline & mean income 1907 & $\begin{array}{l}896 \\
245\end{array}$ & 694 & 1755 & total income/total population & $\begin{array}{l}\text { statistical offices of Baden, } \\
\text { Hesse and Wuerttemberg }\end{array}$ \\
\hline $\begin{array}{l}\text { landholding } \\
\text { inequality }\end{array}$ & landholding gini 1895 & $\begin{array}{l}0.716 \\
0.123\end{array}$ & 0.426 & 0.948 & $\begin{array}{l}\text { For more information about } \\
\text { this measure see Ziblatt (2008). }\end{array}$ & Ziblatt (2008) \\
\hline \multirow[t]{5}{*}{$\begin{array}{l}\text { distribution } \\
\text { of farm sizes }\end{array}$} & $<2$ ha & $\begin{array}{l}8.242 \\
7.031\end{array}$ & 0.65 & 41.86 & $\begin{array}{l}\text { Percentage of farms below } 2 \text { ha } \\
\text { number stated in source }\end{array}$ & Kaiserliches Statistisches Amt (1898) \\
\hline & $2-5$ ha & $\begin{array}{l}13.336 \\
10.692\end{array}$ & 0.76 & 61.71 & $\begin{array}{l}\text { Percentage of farms between } 2-5 \text { ha } \\
\text { number stated in source }\end{array}$ & \\
\hline & 5-20 ha & $\begin{array}{l}33.843 \\
15.044\end{array}$ & 3.03 & 70.54 & $\begin{array}{l}\text { Percentage of farms between 5-20 ha } \\
\text { number stated in source }\end{array}$ & \\
\hline & $20-100$ ha & $\begin{array}{l}27.081 \\
16.055\end{array}$ & 0.3 & 82.17 & $\begin{array}{l}\text { Percentage of farms between } 20-100 \text { ha } \\
\text { number stated in source }\end{array}$ & \\
\hline & $>100$ ha & $\begin{array}{l}17.483 \\
19.319\end{array}$ & 0 & 80.8 & $\begin{array}{l}\text { Percentage of farms above } 100 \text { ha } \\
\text { number stated in source }\end{array}$ & \\
\hline
\end{tabular}

Notes: This table gives an overview of the outcome variables used in Tables 2 and 3 which are our main historical tables. Column 3 shows means and standard deviations in parentheses. Column 4 and 5 show the minimum and the maximum of the variable. The construction of the variables is described in column 6 and the sources are given in column 7. The precise reference for some of the sources can be found in the bibliography. See Table A3 for more details on the data sources used for the computation of top income shares. 
Table A2: Overview of Main Modern Outcome Variables

\begin{tabular}{|c|c|c|c|c|c|c|}
\hline Outcome & & mean (sd) & $\min$ & $\max$ & Explanation & Source \\
\hline \multirow[t]{8}{*}{ income } & $\begin{array}{l}\text { log household } \\
\text { income }\end{array}$ & $\begin{array}{l}6.719 \\
0.115\end{array}$ & 6.448 & 7.46 & Log of household income & \multirow{2}{*}{$\begin{array}{l}\text { Bundesamt für Bauwesen und Raumforschung } \\
\text { INKAR Indikatoren und Karten zur Raum- } \\
\text { und Stadtentwicklung, from www.inkar.de }\end{array}$} \\
\hline & household income & $\begin{array}{c}833.531 \\
103.02\end{array}$ & 631.6 & 1737.281 & $\begin{array}{l}\text { The average monthly household income } \\
\text { in Euro in } 2013 \text { divided by the average }\end{array}$ & \\
\hline & log taxable income & $\begin{array}{c}3.46 \\
0.146\end{array}$ & 3.107 & 4.022 & Log of average taxable income & $\begin{array}{l}\text { Federal Statistical Office of Germany, } \\
\text { from https://www.destatis.de }\end{array}$ \\
\hline & taxable income & $\begin{array}{c}32.181 \\
4.809\end{array}$ & 22.352 & 55.808 & $\begin{array}{l}\text { Average taxable income } \\
\text { in thousand Euro }\end{array}$ & \multirow{5}{*}{$\begin{array}{l}\text { Bundesamt für Bauwesen und Raumforschung, } \\
\text { INKAR Indikatoren und Karten zur Raum- } \\
\text { und Stadtentwicklung, from www.inkar.de }\end{array}$} \\
\hline & $\log$ median & 7.956 & 7.555 & 8.383 & Log of median income & \\
\hline & $\begin{array}{l}\text { income } \\
\text { median income }\end{array}$ & $\begin{array}{c}0.162 \\
2889.439 \\
45.414\end{array}$ & 1910 & 4371 & Median monthly income & \\
\hline & $\log$ GDP p.c & $\begin{array}{l}455.414 \\
3.447 \\
0.336\end{array}$ & 2.674 & 4.964 & Log of GDP p.c. & \\
\hline & GDP p.c & $\begin{array}{l}33.494 \\
14.404\end{array}$ & 14.5 & 143.1 & $\begin{array}{l}\text { GDP p.c. in } 2013 \\
\text { in thousand Euro }\end{array}$ & \\
\hline \multirow[t]{8}{*}{$\begin{array}{l}\text { income } \\
\text { inequality }\end{array}$} & top $10 \%$ income share & $\begin{array}{c}36.9 \\
5.1\end{array}$ & 26.7 & 63.1 & $\begin{array}{l}\text { Pareto interpolation using income tax tabulations, } \\
\text { national accounts and population statistics }\end{array}$ & \multirow[t]{8}{*}{$\begin{array}{l}\text { Federal Statistical Office of Germany and } \\
\text { statistical offices of the Laender }\end{array}$} \\
\hline & top $1 \%$ income share & $\begin{array}{l}10.9 \\
2.8\end{array}$ & 6.7 & 33.6 & $\begin{array}{l}\text { Pareto interpolation using income tax tabulations, } \\
\text { national accounts and population statistics }\end{array}$ & \\
\hline & $\log$ mean income top $10 \%$ & $\begin{array}{c}6.8 \\
0.14\end{array}$ & 6.5 & 7.3 & & \\
\hline & mean income top $10 \%$ & $\begin{array}{c}119,534 \\
29,452\end{array}$ & 72,247 & 318,532 & total income of top $10 \%$ in Euro/ $10 \%$ of population & \\
\hline & $\log$ mean income top $1 \%$ & $\begin{array}{l}12.7 \\
0.32\end{array}$ & 12.1 & 14.4 & & \\
\hline & mean income top $1 \%$ & $\begin{array}{l}357,066 \\
144,362\end{array}$ & 178,810 & $1,844,190$ & total income of top $10 \%$ in Euro/ $10 \%$ of population & \\
\hline & share with income $<10.000$ & $\begin{array}{c}36.7 \\
7.1\end{array}$ & 22.1 & 64.5 & no of tax units with income $<10.000 /$ total population & \\
\hline & share with income $<20.000$ & $\begin{array}{l}51.2 \\
8.0\end{array}$ & 35.1 & 77.3 & no of tax units with income $<20.000 /$ total population & \\
\hline \multirow[t]{2}{*}{$\begin{array}{l}\text { wealth } \\
\text { inequality }\end{array}$} & wealth taxpayers per 10.000 & $\begin{array}{c}149.7 \\
54.9\end{array}$ & 40 & 418 & no of wealth taxpayers/total population in 10.000 & \multirow[t]{2}{*}{$\begin{array}{l}\text { Federal Statistical Office of Germany, } \\
\text { Fachserie 14, Reihe 7.4, Vermögensteuer } \\
\text { Hauptveranlagung 1995, p.119-127. }\end{array}$} \\
\hline & millionaires per 10.000 & $\begin{array}{l}21.4 \\
10.5\end{array}$ & 7 & 89 & $\begin{array}{l}\text { no of tax units with wealth } \\
>1 \mathrm{Mio} \text { DM/total population in } 10.000\end{array}$ & \\
\hline
\end{tabular}

Notes: This table gives an overview of the outcome variables used in Tables 4 and 5 which are our main long-run tables. Column 3 shows means and standard deviations in parentheses. Column 4 and 5 show the minimum and the maximum of the variable. The construction of the variables is described in column 6 and the sources are given in column 7. The precise reference for some of the sources can be found in the bibliography. See Table A3 for more details on the data sources used for the computation of top income shares. 
Table A3: Sources for Income Inequality Measures

\begin{tabular}{|c|c|c|c|}
\hline area & data year & explanation & source \\
\hline Baden & 1895 & income tax tabulations & Statistik der badischen Einkommensteuer 1896, p.52-53 \\
\hline & 1907 & income tax tabulations & Statistisches Jahrbuch für das Großherzogtum Baden 1909, p.634-635 \\
\hline Hesse & 1894 & income tax tabulations & Mittheilungen der Großherzoglich Hessischen Centralstelle für die Landesstatistik 1895, p.226-231 \\
\hline Hesse & 1907 & income tax tabulations & Mittheilungen der Großherzoglich Hessischen Centralstelle für die Landesstatistik 1909, p.4-13,20,27 \\
\hline Wuerttemberg & 1906 & income tax tabulations & Württembergische Jahrbücher für Statistik und Landeskunde 1908, Vol. 1, p.24-28; Vol. 2, p.110-115 \\
\hline German Empire & 1895 & total population (=total no. of potential taxpayers) & Kaiserliches Statisisches Amt (1897) \\
\hline German Empire & 1907 & total population (=total no. of potential taxpayers) & Kaiserliches Statisisches Amt (1910) \\
\hline German Empire & $\begin{array}{c}1873 \\
-1913\end{array}$ & wages & $\begin{array}{l}\text { Kuczynski, J. (1947): Die Geschichte der Lage der Arbeiter in Deutschland } \\
\text { von } 1789 \text { bis in die Gegenwart, Band 1. Tribüne. }\end{array}$ \\
\hline Germany & 2013 & income tax tabulations & $\begin{array}{l}\text { Lohn- und Einkommensteuerstatistik: Kreise (Code 73111-02-01-4), } \\
\text { Federal Statistical Office of Germany, from https://www.regionalstatistik.de }\end{array}$ \\
\hline Germany & 2013 & primary income & $\begin{array}{l}\text { Volkswirtschaftliche Gesamtrechnungen der Länder (Code R2B1, R2B2,R2B3 ) } \\
\text { statistical offices of the Laender, from https://www.vgrdl.de }\end{array}$ \\
\hline Germany & 2011 & marital status & $\begin{array}{l}\text { Census } 2011 \text { (Code 12111-05-01-5), Federal Statistical Office of Germany } \\
\text { from https://www.regionalstatistik.de }\end{array}$ \\
\hline Germany & 2013 & population by age & $\begin{array}{l}\text { Population update (Code 12411-02-03-4), Federal Statistical Office of Germany } \\
\text { from https://www.regionalstatistik.de }\end{array}$ \\
\hline
\end{tabular}

Notes: This table gives an overview on the data sources for our inequality measures used in Tables 5 . Column 3 shows the area covered by the data source. Column 4 shows the data year. The content of the data source is described in column 6 and the respective publications are given in column 7 . 
Table A4: Equal Division and Income Measures 2014 - Quadratic RD Polynomial

\begin{tabular}{|c|c|c|c|c|}
\hline & $\begin{array}{c}(1) \\
\text { Log Household Income }\end{array}$ & $\begin{array}{c}(2) \\
\text { Log Taxable Income }\end{array}$ & $\begin{array}{c}(3) \\
\text { Log Median Income }\end{array}$ & $\begin{array}{c}(4) \\
\text { Log GDP p.c. }\end{array}$ \\
\hline \multicolumn{5}{|l|}{ Panel A. OLS } \\
\hline \multirow[t]{3}{*}{ Equal Division } & $0.0700^{* * *}$ & $0.0739^{* * *}$ & $0.0501^{* * *}$ & $0.133^{* *}$ \\
\hline & $(0.0223)$ & $(0.0209)$ & $(0.0181)$ & $(0.0554)$ \\
\hline & {$[0.0161]$} & {$[0.0189]$} & {$[0.0152]$} & {$[0.0359]$} \\
\hline Observations & 397 & 374 & 397 & 397 \\
\hline \multicolumn{5}{|c|}{ Panel B. With Controls } \\
\hline \multirow[t]{3}{*}{ Equal Division } & $0.0569^{* * *}$ & $0.0573^{* * *}$ & $0.0424^{* * *}$ & $0.136^{* * *}$ \\
\hline & $(0.0186)$ & $(0.0177)$ & $(0.0109)$ & $(0.0362)$ \\
\hline & {$[0.0143]$} & {$[0.0170]$} & {$[0.0139]$} & {$[0.0368]$} \\
\hline Observations & 397 & 374 & 397 & 397 \\
\hline \multicolumn{5}{|c|}{ Panel C. Distance to Border } \\
\hline \multirow[t]{3}{*}{ Equal Division } & $0.0488^{* *}$ & $0.0506^{* * *}$ & $0.0434^{* * *}$ & $0.146^{* *}$ \\
\hline & $(0.0187)$ & $(0.0159)$ & $(0.0123)$ & $(0.0539)$ \\
\hline & {$[0.0175]$} & {$[0.0211]$} & {$[0.0149]$} & {$[0.0600]$} \\
\hline Observations & 198 & 178 & 198 & 198 \\
\hline \multicolumn{5}{|c|}{ Panel D. Distance to Border $\times$ Equal Division } \\
\hline \multirow[t]{3}{*}{ Equal Division } & 0.0377 & 0.0318 & 0.0238 & 0.0981 \\
\hline & $(0.0262)$ & $(0.0236)$ & $(0.0142)$ & $(0.0690)$ \\
\hline & {$[0.0157]$} & {$[0.0176]$} & {$[0.0139]$} & {$[0.0521]$} \\
\hline Observations & 198 & 178 & 198 & 198 \\
\hline Mean Outcome & 6.719 & 3.461 & 7.956 & 3.447 \\
\hline SD Outcome & 0.115 & 0.146 & 0.162 & 0.336 \\
\hline
\end{tabular}

Notes: Data on income and GDP per capita stem from the Federal Statistical Office of Germany and INKAR of 2013/14. In comparison to table 3 this table includes a quadratic RD polynomial in all panels. Panel A includes longitude, latitude, and statefixed effects. Panel B additionally includes geographic and cultural controls as specified in summary statistics. Panel C reduces the sample to counties in $35 \mathrm{~km}$ distance to the border of the inheritance rule. Panel D additionally includes an interaction term between distance to the border and treatment allowing the slope to vary on either side of the border. Counties with more than 100.000 inhabitants are excluded. Regressions are weighted by population. Standard errors clustered at the district (Regierungsbezirk) level. Conley standard errors in square brackets. ${ }^{*} \mathrm{p}<0.1,{ }^{* *} \mathrm{p}<0.05,{ }^{* * *} \mathrm{p}<0.01$ 
Table A5: Equal Division and Farm Sizes in Prussia 1816
$(1)$
$(2)$
(3)

Small Landholdings Medium Landholdings Large Landholdings (per 1000 People)

\begin{tabular}{|c|c|c|c|}
\hline \multicolumn{4}{|l|}{ Panel A. OLS } \\
\hline Equal Division & $\begin{array}{c}26.32^{* * *} \\
(7.614)\end{array}$ & $\begin{array}{c}13.47 \\
(7.969)\end{array}$ & $\begin{array}{c}-0.291 \\
(0.264)\end{array}$ \\
\hline Observations & 305 & 305 & 305 \\
\hline \multicolumn{4}{|c|}{ Panel B. With Controls } \\
\hline Equal Division & $\begin{array}{c}21.33^{* * * *} \\
(5.706)\end{array}$ & $\begin{array}{c}7.484 \\
(5.465)\end{array}$ & $\begin{array}{c}0.0333 \\
(0.178)\end{array}$ \\
\hline Observations & 305 & 305 & 305 \\
\hline \multicolumn{4}{|c|}{ Panel C. Distance to Border } \\
\hline Equal Division & $\begin{array}{l}8.472^{*} \\
(4.666)\end{array}$ & $\begin{array}{c}2.327 \\
(6.067)\end{array}$ & $\begin{array}{c}0.0550 \\
(0.166)\end{array}$ \\
\hline Observations & 123 & 123 & 123 \\
\hline Mean Outcome & 50.10 & 40.42 & 1.340 \\
\hline SD Outcome & 37.12 & 21.96 & 1.496 \\
\hline
\end{tabular}

Notes: This table uses the earliest available measure of the distribution of farm sizes of German lands from Prussia in 1816 . Column 1 shows the percent of small landholdings per 1000 people. Column 2 the percent of medium landholdings and column 3 the percent of large landholdings per 1000 people. Panel A includes longitude, latitude, and state-fixed effects. Panel B additionally includes geographic and cultural controls as specified in summary statistics. Panel C reduces the sample to counties in $35 \mathrm{~km}$ distance to the border of the inheritance rule. Regressions are weighted by population. Standard errors clustered at the district (Regierungsbezirk) level. * $\mathrm{p}<0.1,{ }^{* *} \mathrm{p}<0.05,{ }^{* * *} \mathrm{p}<0.01$ 
Table A6: Change in Farm Sizes and Their Distribution

\begin{tabular}{|c|c|c|c|c|c|c|}
\hline & $\begin{array}{l}(1) \\
\text { Average Farmsize ha }\end{array}$ & $\begin{aligned} & (2) \\
< & 2 \text { ha }\end{aligned}$ & $\begin{array}{c}(3) \\
2-5 \text { ha }\end{array}$ & $\begin{array}{c}(4) \\
5-20 \text { ha }\end{array}$ & $\begin{array}{c}(5) \\
20-100 \text { ha }\end{array}$ & $\begin{aligned} & (6) \\
> & 100 \text { ha }\end{aligned}$ \\
\hline \multicolumn{7}{|l|}{ Panel A. OLS } \\
\hline Equal Division x 1907 & $\begin{array}{c}-0.288^{* * *} \\
(0.105)\end{array}$ & $\begin{array}{l}1.018^{* *} \\
(0.434)\end{array}$ & $\begin{array}{c}0.212 \\
(0.351)\end{array}$ & $\begin{array}{c}-3.068^{* * *} \\
(0.538)\end{array}$ & $\begin{array}{c}0.869 \\
(0.777)\end{array}$ & $\begin{array}{c}0.935 \\
(0.566)\end{array}$ \\
\hline Observations & 1870 & 1873 & 1873 & 1873 & 1871 & 1739 \\
\hline \multicolumn{7}{|l|}{ Panel B. With Controls } \\
\hline Equal Division x 1907 & $\begin{array}{c}-0.279^{* * *} \\
(0.103)\end{array}$ & $\begin{array}{l}1.027^{* *} \\
(0.423)\end{array}$ & $\begin{array}{c}0.275 \\
(0.310)\end{array}$ & $\begin{array}{c}-2.987^{* * *} \\
(0.524)\end{array}$ & $\begin{array}{c}0.716 \\
(0.710)\end{array}$ & $\begin{array}{c}0.850 \\
(0.596)\end{array}$ \\
\hline Observations & 1870 & 1873 & 1873 & 1873 & 1871 & 1739 \\
\hline \multicolumn{7}{|c|}{ Panel C. Distance to Border } \\
\hline Equal Division x 1907 & $\begin{array}{l}-0.221^{* *} \\
(0.0959)\end{array}$ & $\begin{array}{c}1.513^{* * *} \\
(0.511)\end{array}$ & $\begin{array}{c}0.155 \\
(0.354)\end{array}$ & $\begin{array}{c}-3.112^{* * *} \\
(0.665)\end{array}$ & $\begin{array}{l}1.624^{* *} \\
(0.793)\end{array}$ & $\begin{array}{l}0.0294 \\
(0.644)\end{array}$ \\
\hline Observations & 795 & 798 & 798 & 798 & 796 & 715 \\
\hline Mean Outcome & 5.818 & 8.607 & 13.60 & 35.05 & 26.49 & 17.46 \\
\hline SD Outcome & 3.403 & 7.636 & 10.95 & 15.07 & 16.02 & 18.68 \\
\hline \multicolumn{7}{|c|}{$\begin{array}{l}\text { Notes: Average farm size and shares of farms in } 5 \text { size categories as stated in 'Statistik des Deutschen Reichs' Vol. } 109(1895) \text { and } \\
\text { Vol. 209(1907). The regressor is the interaction term of 'equal division' (compared to 'unequal division') and year } 1907 \text { (compared } \\
\text { to 1895). The results show the change in farm sizes between } 1895 \text { and } 1907 \text {. Panel A includes besides main effects longitude, } \\
\text { latitude, and state-fixed effects. Panel B additionally includes geographic and cultural controls as specified in summary statistics. } \\
\text { Panel C reduces the sample to counties in } 35 \mathrm{~km} \text { distance to the border of the inheritance rule. Independent cities are excluded. } \\
\text { Regressions are weighted by population. Standard errors clustered at the district (Regierungsbezirk) level. * p }<0.1,{ }^{* *} \text { p }<0.05 \text {, } \\
* * * ~ p<0.01\end{array}$} \\
\hline
\end{tabular}

Table A7: Equal Division and Income Inequality 1895 and 1907

\begin{tabular}{|c|c|c|c|c|c|c|c|c|}
\hline & $\begin{array}{c}(1) \\
\text { top } 10 \% \\
\text { Inc Share } \\
1895\end{array}$ & $\begin{array}{c}(2) \\
\text { Top 1\% } \\
\text { Inc Share } \\
1895\end{array}$ & $\begin{array}{c}(3) \\
\text { Ratio } \\
1 / 90 \\
1895\end{array}$ & $\begin{array}{c}(4) \\
\text { Log Mean } \\
\text { Income } \\
1895\end{array}$ & $\begin{array}{c}(5) \\
\text { Top } 10 \% \\
\text { Inc share } \\
1907\end{array}$ & $\begin{array}{c}(6) \\
\text { Top 1\% } \\
\text { Inc Share } \\
1907\end{array}$ & $\begin{array}{c}(7) \\
\text { Ratio } \\
1 / 90 \\
1907\end{array}$ & $\begin{array}{c}(8) \\
\text { Log Mean } \\
\text { Income } \\
1907\end{array}$ \\
\hline \multicolumn{9}{|l|}{ Panel A. OLS } \\
\hline Equal Division & $\begin{array}{c}0.872 \\
(1.864)\end{array}$ & $\begin{array}{c}0.275 \\
(1.102)\end{array}$ & $\begin{array}{c}0.581 \\
(2.130)\end{array}$ & $\begin{array}{c}0.0380 \\
(0.0410)\end{array}$ & $\begin{array}{c}0.154 \\
(1.365)\end{array}$ & $\begin{array}{l}-0.110 \\
(0.856)\end{array}$ & $\begin{array}{c}-0.0882 \\
(1.724)\end{array}$ & $\begin{array}{c}0.0507 \\
(0.0412)\end{array}$ \\
\hline Observations & 70 & 70 & 70 & 70 & 133 & 133 & 133 & 133 \\
\hline \multicolumn{9}{|c|}{ Panel B. With Controls } \\
\hline Equal Division & $\begin{array}{l}-0.835 \\
(2.455)\end{array}$ & $\begin{array}{l}-0.378 \\
(1.524)\end{array}$ & $\begin{array}{l}-1.031 \\
(2.878)\end{array}$ & $\begin{array}{c}-0.0171 \\
(0.0505)\end{array}$ & $\begin{array}{c}-1.227 \\
(1.603)\end{array}$ & $\begin{array}{c}-0.899 \\
(1.071)\end{array}$ & $\begin{array}{l}-1.716 \\
(2.087)\end{array}$ & $\begin{array}{c}-0.0107 \\
(0.0436)\end{array}$ \\
\hline Observations & 70 & 70 & 70 & 70 & 133 & 133 & 133 & 133 \\
\hline \multicolumn{9}{|c|}{ Panel C. Distance to Border } \\
\hline Equal Division & $\begin{array}{c}0.587 \\
(2.424)\end{array}$ & $\begin{array}{c}0.160 \\
(1.626)\end{array}$ & $\begin{array}{c}0.191 \\
(3.059)\end{array}$ & $\begin{array}{c}0.0224 \\
(0.0483)\end{array}$ & $\begin{array}{l}-0.388 \\
(1.357)\end{array}$ & $\begin{array}{l}-0.526 \\
(0.984)\end{array}$ & $\begin{array}{l}-0.866 \\
(1.868)\end{array}$ & $\begin{array}{c}0.0161 \\
(0.0355)\end{array}$ \\
\hline Observations & 64 & 64 & 64 & 64 & 119 & 119 & 119 & 119 \\
\hline Mean Outcome & 33.00 & 10.43 & 16.42 & 6.857 & 37.59 & 11.95 & 19.87 & 6.844 \\
\hline SD Outcome & 7.096 & 4.042 & 8.552 & 0.187 & 7.403 & 3.520 & 7.356 & 0.301 \\
\hline
\end{tabular}

Notes: The table reports the effect of equal division on the outcomes reported in the column headers. The unit of observation is a county. County income tax tabulations are from the annual publications of the statistical offices of Baden $(1895,1907)$, Hesse $(1894,1907)$ and Württemberg (1907). Panel A includes longitude, latitude, and state-fixed effects. Panel B additionally includes geographic and cultural controls as specified in summary statistics. Panel C reduces the sample to counties in $35 \mathrm{~km}$ distance to the border of the inheritance rule. Independent cities are excluded. Regressions are weighted by population. Standard errors clustered at the district (Regierungsbezirk) level. ${ }^{*} \mathrm{p}<0.1,{ }^{* *} \mathrm{p}<0.05,{ }^{* * *} \mathrm{p}<0.01$ 
Table A8: Landholding Inequality 1895 in Prussia

\begin{tabular}{|c|c|c|c|c|c|c|}
\hline & \multicolumn{2}{|c|}{ Landholding Gini Coeff. 1895} & \multicolumn{4}{|c|}{$\%$ Farms in Size Category... } \\
\hline & $(1)$ & $(2)$ & $(3)$ & $(4)$ & $(5)$ & $(6)$ \\
\hline & Linear RD Polyn. & Quad. RD Polyn. & $<2$ ha & $2-5$ ha & $5-20$ ha & 20-100 ha \\
\hline \multicolumn{7}{|l|}{ Panel A. OLS } \\
\hline \multirow[t]{2}{*}{ Equal Division } & $-0.0612^{* *}$ & $-0.0562^{*}$ & $5.268^{* * *}$ & $9.776^{* * *}$ & 1.841 & $-14.61^{* * *}$ \\
\hline & $(0.0290)$ & $(0.0314)$ & $(1.856)$ & $(2.065)$ & $(2.465)$ & $(2.781)$ \\
\hline Observations & 490 & 490 & 488 & 488 & 488 & 488 \\
\hline \multicolumn{7}{|c|}{ Panel B. With Controls } \\
\hline \multirow[t]{2}{*}{ Equal Division } & $-0.0490^{* * *}$ & $-0.0471^{* * *}$ & $5.970^{* * *}$ & $9.381^{* * *}$ & -2.524 & $-13.10^{* * *}$ \\
\hline & $(0.0169)$ & $(0.0170)$ & $(1.273)$ & $(1.573)$ & $(2.754)$ & $(2.380)$ \\
\hline Observations & 490 & 490 & 488 & 488 & 488 & 488 \\
\hline \multicolumn{7}{|c|}{ Panel C. Distance to Border } \\
\hline \multirow[t]{2}{*}{ Equal Division } & $-0.0423^{* * *}$ & $-0.0450^{* * *}$ & $5.169^{* * *}$ & $8.055^{* * *}$ & -3.138 & $-8.303^{* * *}$ \\
\hline & $(0.0114)$ & $(0.0134)$ & $(1.289)$ & $(1.608)$ & $(1.973)$ & $(2.486)$ \\
\hline Observations & 157 & 157 & 155 & 155 & 155 & 155 \\
\hline Mean Outcome & 0.770 & 0.770 & 7.627 & 10.45 & 27.97 & 29.23 \\
\hline SD Outcome & 0.0975 & 0.0975 & 6.727 & 8.458 & 12.56 & 15.92 \\
\hline
\end{tabular}

Notes: This table shows the results of table 2 for Prussia only. Share of farms in 5 size categories as stated in 'Statistik des Deutschen Reichs' Vol. 109. Panel A includes longitude, latitude, and state-fixed effects. Panel additionally B includes geographic and cultural controls as specified in summary statistics. Panel C reduces the sample to counties in $35 \mathrm{~km}$ distance to the border of the inheritance rule. Independent cities are excluded. Regressions are weighted by population. Standard errors clustered at the district (Regierungsbezirk) level. ${ }^{*} \mathrm{p}<0.1,{ }^{* *} \mathrm{p}<0.05,{ }^{* * *} \mathrm{p}<0.01$

Table A9: Landholding Inequality 1895 in Bavaria

\begin{tabular}{|c|c|c|c|c|c|c|}
\hline & \multicolumn{2}{|c|}{ Landholding Gini Coeff. 1895} & \multicolumn{4}{|c|}{$\%$ Farms in Size Category... } \\
\hline & $(1)$ & $(2)$ & $(3)$ & $(4)$ & $(5)$ & $(6)$ \\
\hline & Linear RD Polyn. & Quad. RD Üolyn. & $<2$ ha & $2-5$ ha & $5-20$ ha & $20-100$ ha \\
\hline \multicolumn{7}{|l|}{ Panel A. OLS } \\
\hline \multirow[t]{2}{*}{ Equal Division } & 0.0232 & -0.00513 & 3.321 & 2.706 & -4.445 & -2.872 \\
\hline & $(0.0286)$ & $(0.0182)$ & $(2.424)$ & $(2.524)$ & $(5.379)$ & $(2.779)$ \\
\hline Observations & 189 & 189 & 190 & 190 & 190 & 190 \\
\hline \multicolumn{7}{|c|}{ Panel B. With Controls } \\
\hline \multirow[t]{2}{*}{ Equal Division } & 0.00820 & 0.00519 & $-1.426^{* *}$ & $-4.663^{*}$ & 3.013 & 1.507 \\
\hline & $(0.0137)$ & $(0.0124)$ & $(0.590)$ & $(2.005)$ & $(3.714)$ & $(2.933)$ \\
\hline Observations & 189 & 189 & 190 & 190 & 190 & 190 \\
\hline \multicolumn{7}{|c|}{ Panel C. Distance to Border } \\
\hline \multirow[t]{2}{*}{ Equal Division } & 0.00283 & 0.000992 & -0.703 & -2.821 & 2.410 & 0.509 \\
\hline & $(0.0114)$ & $(0.00974)$ & $(0.445)$ & $(2.274)$ & $(2.769)$ & $(2.363)$ \\
\hline Observations & 84 & 84 & 84 & 84 & 84 & 84 \\
\hline Mean Outcome & 0.557 & 0.557 & 5.353 & 14.98 & 49.75 & 27.27 \\
\hline SD Outcome & 0.0549 & 0.0549 & 5.084 & 8.552 & 10.27 & 14.43 \\
\hline
\end{tabular}

Notes: This table shows the results of table 2 for Bavaria only. Share of farms in 5 size categories as stated in 'Statistik des Deutschen Reichs' Vol. 109. Panel A includes longitude, latitude, and state-fixed effects. Panel B additionally includes geographic and cultural controls as specified in summary statistics. Panel C reduces the sample to counties in $35 \mathrm{~km}$ distance to the border of the inheritance rule. Independent cities are excluded. Regressions are weighted by population. Standard errors clustered at the district (Regierungsbezirk) level. ${ }^{*} \mathrm{p}<0.1,{ }^{* *} \mathrm{p}<0.05,{ }^{* * *} \mathrm{p}<0.01$ 
Table A10: Equal Division and Income and Wages, 1878 and 1895

\begin{tabular}{|c|c|c|c|c|c|}
\hline & \multicolumn{4}{|c|}{ Income and County Taxes 1878} & \multirow{2}{*}{$\begin{array}{c}\text { Daily Wages } \\
(5) \\
\text { Males } 1892\end{array}$} \\
\hline & $\begin{array}{l}(1) \\
\text { Federal Class Tax }\end{array}$ & $\begin{array}{c}(2) \\
\text { Federal Income Tax } \\
\text { (per }\end{array}$ & $\begin{array}{l}\text { (3) } \\
\text { Local County Tax } \\
\text { Capita) }\end{array}$ & $\begin{array}{c}(4) \\
\text { Total County Income }\end{array}$ & \\
\hline \multicolumn{6}{|l|}{ Panel A. OLS } \\
\hline \multirow[t]{2}{*}{ Equal Division } & $-0.141^{*}$ & -0.0815 & 0.0449 & -0.420 & 0.100 \\
\hline & $(0.0802)$ & $(0.129)$ & $(0.172)$ & $(0.341)$ & $(0.0761)$ \\
\hline Observations & 415 & 415 & 415 & 415 & 413 \\
\hline \multicolumn{6}{|c|}{ Panel B. With Controls } \\
\hline \multirow[t]{2}{*}{ Equal Division } & $-0.125^{*}$ & 0.0958 & 0.0885 & 0.0465 & 0.0596 \\
\hline & $(0.0682)$ & $(0.110)$ & $(0.122)$ & $(0.275)$ & $(0.0780)$ \\
\hline Observations & 415 & 415 & 415 & 415 & 413 \\
\hline \multicolumn{6}{|c|}{ Panel C. Distance to Border } \\
\hline \multirow[t]{2}{*}{ Equal Division } & $-0.157^{* * *}$ & 0.0946 & 0.118 & -0.00813 & 0.0317 \\
\hline & $(0.0496)$ & $(0.116)$ & $(0.121)$ & $(0.242)$ & $(0.0667)$ \\
\hline Observations & 190 & 190 & 190 & 190 & 189 \\
\hline Mean Outcome & 1.376 & 0.624 & 1.010 & 2.068 & 1.487 \\
\hline SD Outcome & 0.390 & 0.441 & 0.792 & 2.777 & 0.356 \\
\hline
\end{tabular}

Notes: The table reports the effect of equal division on the outcomes reported in the column headers. The unit of observation is a county. The table uses various measures of tax income per person in each Prussian county in 1878 as outcome variables (column 1-4). The outcome variables in column 1 and 2 come close to an income tax while taxes in column 3 and 4 are local community taxes. In column 5 it uses daily wages for males in 1892 in Prussia as outcome variable. Panel A includes longitude, latitude, and state-fixed effects. Panel B additionally includes geographic and cultural controls as specified in summary statistics. Panel C reduces the sample to counties in $35 \mathrm{~km}$ distance to the border of the inheritance rule. Regressions are weighted by population. Standard errors clustered at the district (Regierungsbezirk) level. ${ }^{*} \mathrm{p}<0.1,{ }^{* *} \mathrm{p}<0.05,{ }^{* * *} \mathrm{p}<0.01$ 
Table A11: Equal Division and Education 1886

\begin{tabular}{|c|c|c|c|c|c|c|}
\hline & \multicolumn{2}{|l|}{1871} & \multicolumn{2}{|c|}{1816} & \multicolumn{2}{|c|}{1886} \\
\hline & $\begin{array}{l}\quad(1) \\
\text { Percent Able to } \\
\text { Read and Write }\end{array}$ & $\begin{array}{c}(2) \\
\text { Percent } \\
\text { Illiterate }\end{array}$ & $\begin{array}{c}(3) \\
\text { Schools }\end{array}$ & $\begin{array}{l}\quad(4) \\
\text { Pupils } \\
\text { (per } 1000\end{array}$ & $\begin{array}{c}(5) \\
\text { Schools } \\
\text { People) }\end{array}$ & $\begin{array}{c}(6) \\
\text { Pupils }\end{array}$ \\
\hline \multicolumn{7}{|l|}{ Panel A. OLS } \\
\hline Equal Division & $\begin{array}{c}-6.103^{* *} \\
(2.528)\end{array}$ & $\begin{array}{l}4.564^{* *} \\
(1.737)\end{array}$ & $\begin{array}{c}0.0609 \\
(0.227)\end{array}$ & $\begin{array}{c}-32.82^{* * *} \\
(9.807)\end{array}$ & $\begin{array}{c}0.203 \\
(0.160)\end{array}$ & $\begin{array}{c}1.808 \\
(13.04)\end{array}$ \\
\hline Observations & 415 & 415 & 308 & 305 & 415 & 415 \\
\hline \multicolumn{7}{|c|}{ Panel B. With Controls } \\
\hline Equal Division & $\begin{array}{l}-1.135 \\
(1.824)\end{array}$ & $\begin{array}{l}-0.102 \\
(1.035)\end{array}$ & $\begin{array}{c}0.414 \\
(0.247)\end{array}$ & $\begin{array}{l}-3.967 \\
(10.55)\end{array}$ & $\begin{array}{l}0.0144 \\
(0.168)\end{array}$ & $\begin{array}{l}-10.59 \\
(13.52)\end{array}$ \\
\hline Observations & 415 & 415 & 308 & 305 & 415 & 415 \\
\hline \multicolumn{7}{|c|}{ Panel C. Distance to Border } \\
\hline Equal Division & $\begin{array}{r}-0.0543 \\
(1.847)\end{array}$ & $\begin{array}{l}-0.574 \\
(0.629)\end{array}$ & $\begin{array}{l}0.0395 \\
(0.111)\end{array}$ & $\begin{array}{l}-4.428 \\
(8.813)\end{array}$ & $\begin{array}{c}-0.114 \\
(0.150)\end{array}$ & $\begin{array}{l}-15.70 \\
(15.63)\end{array}$ \\
\hline Observations & 190 & 190 & 90 & 87 & 190 & 190 \\
\hline Mean Outcome & 62.57 & 9.544 & 1.928 & 110.7 & 1.328 & 169.8 \\
\hline SD Outcome & 12.03 & 9.305 & 0.923 & 43.72 & 0.533 & 43.13 \\
\hline
\end{tabular}

Notes: The table reports the effect of equal division on the outcomes reported in the column headers. The unit of observation is a county. The table uses data on education levels in Prussia as outcome variables. In column 1 and 2 the data stems from 1871 and shows the percent of the population which is able to read and write. In column 2 the percent of illiterate people is used. Earliest measures of education come from the documented number of schools and pupils in Prussian counties in 1816 (column 3 and 4). In 1886 the same measures are documented for Prussia again. Panel A includes longitude, latitude, and state-fixed effects. Panel B additionally includes geographic and cultural controls as specified in summary statistics. Panel C reduces the sample to counties in $35 \mathrm{~km}$ distance to the border of the inheritance rule. Regressions are weighted by population. Standard errors clustered at the district (Regierungsbezirk) level. ${ }^{*} \mathrm{p}<0.1,{ }^{* *} \mathrm{p}<0.05,{ }^{* * *} \mathrm{p}<0.01$ 
Table A12: Sectoral Employment in Prussia 1882

\begin{tabular}{lccc}
\hline & $(1)$ & $(2)$ & $(3)$ \\
& Agric. & Manuf. & Trade and Services \\
\hline Panel A. OLS & & & \\
Equal Division & 0.720 & -1.481 & 0.364 \\
& $(1.872)$ & $(1.791)$ & $(0.383)$ \\
Observations & 415 & 415 & 415 \\
\hline Panel B. With Controls & & \\
Equal Division & -0.820 & -0.686 & $0.753^{* *}$ \\
& $(1.801)$ & $(2.057)$ & $(0.346)$ \\
Observations & 415 & 415 & 415 \\
\hline Panel C. Distance to Border & \\
Equal Division & -0.765 & 0.489 & $0.724^{* * *}$ \\
& $(1.411)$ & $(1.578)$ & $(0.229)$ \\
Observations & 190 & 190 & 190 \\
\hline Mean Outcome & 20.68 & 12.40 & 2.636 \\
SD Outcome & 6.907 & 6.584 & 1.481 \\
\hline
\end{tabular}

Notes: This table uses the percentage of people in the three main economic sectors: agriculture, manufacturing, and trade and services as outcome variables. The sample stems from 1882 Prussia. Panel A includes longitude, latitude, and state-fixed effects. Panel B additionally includes geographic and cultural controls as specified in summary statistics. Panel C reduces the sample to counties in $35 \mathrm{~km}$ distance to the border of the inheritance rule. Regressions are weighted by population. Standard errors clustered at the district (Regierungsbezirk) level. ${ }^{*} \mathrm{p}<0.1,{ }^{* *} \mathrm{p}<0.05,{ }^{* * *} \mathrm{p}<0.01$

Table A13: Height of Bavarian conscripts in $19^{\text {th }}$ century

\begin{tabular}{|c|c|c|}
\hline & $\begin{array}{c}(1) \\
\text { Height }(\mathrm{cm})\end{array}$ & $\begin{array}{c}(2) \\
\text { SD }(\mathrm{cm}) \text { within County }\end{array}$ \\
\hline \multicolumn{3}{|c|}{ Panel A. OLS with Individual Controls } \\
\hline Equal Division & $\begin{array}{c}-0.345^{* *} \\
(0.155)\end{array}$ & $\begin{array}{c}-0.166^{* * *} \\
(0.00258)\end{array}$ \\
\hline Observations & 19048 & 19048 \\
\hline \multicolumn{3}{|c|}{ Panel B. Additional Geographic Controls } \\
\hline Equal Division & $\begin{array}{c}1.097 \\
(1.645)\end{array}$ & $\begin{array}{c}-3.182^{* * *} \\
(0.187)\end{array}$ \\
\hline Observations & 19047 & 19047 \\
\hline \multicolumn{3}{|c|}{ Panel C. Border Sample } \\
\hline Equal Division & $\begin{array}{l}0.0717 \\
(1.235)\end{array}$ & $\begin{array}{l}-0.265^{* * *} \\
(6.71 \mathrm{e}-12)\end{array}$ \\
\hline Observations & 4982 & 4982 \\
\hline Mean Outcome & 165.6 & 6.250 \\
\hline SD Outcome & 6.353 & 0.201 \\
\hline
\end{tabular}

Notes: The table uses absolute height in centimeter of Bavarian conscripts in the 19th century as outcome variable in column 1. Column 2 uses the standard deviation of height in centimeter within a Bavarian county as outcome variable. The variation in equal division comes from the county level. There are 181 counties in the sample. Panel A includes longitude, latitude, and state-fixed effects. Panel B additionally includes geographic and cultural controls as specified in summary statistics. Panel C reduces the sample to counties in $35 \mathrm{~km}$ distance to the border of the inheritance rule. Regressions are weighted by population. Standard errors clustered at the district (Regierungsbezirk) level. ${ }^{*} \mathrm{p}<0.1,{ }^{* *} \mathrm{p}<0.05,{ }^{* * *} \mathrm{p}<0.01$ 
Table A14: Deposits at and Credit from Savings Banks and Credit Associations 1895 and 1907

\begin{tabular}{lcccccc}
\hline & $\begin{array}{c}(1) \\
\text { Depositors pc } \\
(1895)\end{array}$ & $\begin{array}{c}(2) \\
\text { Depositors pc } \\
(1907)\end{array}$ & $\begin{array}{c}(3) \\
\text { Deposits pc } \\
(1895)\end{array}$ & $\begin{array}{c}(4) \\
\text { Deposits pc } \\
(1907)\end{array}$ & $\begin{array}{c}(5) \\
\text { Credit pc } \\
(1895)\end{array}$ & $\begin{array}{c}\text { Credit pc } \\
(1907)\end{array}$ \\
\hline Panel A. OLS & & & & & & \\
Equal Division & 0.0101 & 0.0227 & 2.563 & -2.809 & $10.49^{*}$ & $-81.96^{*}$ \\
& $(0.0158)$ & $(0.0351)$ & $(9.006)$ & $(27.37)$ & $(5.610)$ & $(39.21)$ \\
Observations & 69 & 70 & 126 & 70 & 124 & 69 \\
\hline Panel B. With Controls & -0.00398 & 0.00946 & -7.438 & -34.65 & -4.083 & -64.75 \\
Equal Division & $(0.0214)$ & $(0.0377)$ & $(12.37)$ & $(47.49)$ & $(5.228)$ & $(47.27)$ \\
Observations & 69 & 70 & 126 & 70 & 124 & 69 \\
\hline Panel C. Distance to Border & 0.0000760 & 0.0271 & -3.240 & -19.67 & 2.342 & -25.25 \\
Equal Division & $(0.0170)$ & $(0.0308)$ & $(10.49)$ & $(33.96)$ & $(4.017)$ & $(44.78)$ \\
Observations & 63 & 64 & 112 & 64 & 110 & 63 \\
\hline Mean Outcome & 0.186 & 0.257 & 98.60 & 296.5 & 61.74 & 234.6 \\
SD Outcome & 0.0616 & 0.0891 & 112.3 & 159.2 & 59.43 & 151.0 \\
\hline
\end{tabular}

Notes: The table uses per capita data from local savings banks (Baden, Hesse, Württemberg) and credit associations (Baden) aggregated at the county level. The number of savings banks' depositors is available in Baden and Hesse, deposits in RM at savings banks in Baden, Hesse and Württemberg (only 1895) and credit in RM in Baden (only credit associations), Hesse and Württemberg (only 1895). Sources are Statistisches Jahrbuch für das Großherzogtum Baden 1895/6 and 1908/9, Mitteilungen der Großherzoglich Hessischen Zentralstelle für Landesstatistik 1895 and 1909, and Statistisches Handbuch für das Königreich Württemberg 1896. Panel A includes longitude, latitude, and state-fixed effects. Panel B additionally includes geographic and cultural controls as specified in summary statistics. Panel $\mathrm{C}$ reduces the sample to counties in $35 \mathrm{~km}$ distance to the border of the inheritance rule. Regressions are weighted by population. Standard errors clustered at the district (Regierungsbezirk) level. ${ }^{*} \mathrm{p}<0.1,{ }^{* *} \mathrm{p}<0.05, * * * \mathrm{p}<0.01$ 
Table A15: Equal Division and the Composition of Income and Wealth

\begin{tabular}{|c|c|c|c|c|c|c|c|}
\hline & $\begin{array}{c}(1) \\
\text { Business } \\
\text { Income (pc) }\end{array}$ & $\begin{array}{c}(2) \\
\text { Real Estate } \\
\text { Income (pc) }\end{array}$ & $\begin{array}{c}(3) \\
\text { Capital } \\
\text { Income (pc) }\end{array}$ & $\begin{array}{c}(4) \\
\text { Labor } \\
\text { Income (pc) }\end{array}$ & $\begin{array}{c}(5) \\
\text { Business } \\
\text { Assets (pc) }\end{array}$ & $\begin{array}{c}\quad(6) \\
\text { Real Estate } \\
\text { Assets (pc) }\end{array}$ & $\begin{array}{c}(7) \\
\text { Financial } \\
\text { Assets (pc) }\end{array}$ \\
\hline \multicolumn{8}{|l|}{ Panel A. OLS } \\
\hline Equal Division & $\begin{array}{l}40.99^{*} \\
(21.06)\end{array}$ & $\begin{array}{l}-4.810 \\
(9.933)\end{array}$ & $\begin{array}{c}23.31 \\
(27.24)\end{array}$ & $\begin{array}{c}91.75 \\
(58.27)\end{array}$ & $\begin{array}{c}54.92 \\
(59.65)\end{array}$ & $\begin{array}{c}-302.7^{* *} \\
(121.5)\end{array}$ & $\begin{array}{l}-248.6 \\
(380.2)\end{array}$ \\
\hline Observations & 115 & 115 & 115 & 115 & 70 & 70 & 70 \\
\hline \multicolumn{8}{|c|}{ Panel B. With Controls } \\
\hline Equal Division & $\begin{array}{c}22.07^{*} \\
(10.88)\end{array}$ & $\begin{array}{l}-14.01 \\
(9.242)\end{array}$ & $\begin{array}{c}4.020 \\
(12.09)\end{array}$ & $\begin{array}{c}41.83 \\
(25.71)\end{array}$ & $\begin{array}{l}-23.45 \\
(100.5)\end{array}$ & $\begin{array}{c}-571.1^{* * *} \\
(126.9)\end{array}$ & $\begin{array}{l}-452.1 \\
(326.9)\end{array}$ \\
\hline Observations & 115 & 115 & 115 & 115 & 70 & 70 & 70 \\
\hline \multicolumn{8}{|c|}{ Panel C. Distance to Border } \\
\hline Equal Division & $\begin{array}{c}21.24^{*} \\
(10.62)\end{array}$ & $\begin{array}{l}-13.92 \\
(9.730)\end{array}$ & $\begin{array}{c}3.573 \\
(13.64)\end{array}$ & $\begin{array}{c}39.98 \\
(25.22)\end{array}$ & $\begin{array}{c}31.80 \\
(85.35)\end{array}$ & $\begin{array}{c}-473.2^{* * *} \\
(101.2)\end{array}$ & $\begin{array}{l}-210.1 \\
(299.1)\end{array}$ \\
\hline Observations & 106 & 106 & 106 & 106 & 64 & 64 & 64 \\
\hline Mean Outcome & 109.0 & 127.1 & 57.14 & 188.0 & 574.3 & 2668.7 & 1240.5 \\
\hline SD Outcome & 116.8 & 54.75 & 114.0 & 245.3 & 441.1 & 931.0 & 954.0 \\
\hline
\end{tabular}

Notes: The table uses county level aggregates from the wealth tax collection in Baden 1908 and Hesse 1907 as well as income tax collection in Baden 1908 and Württemberg 1907. Income tax statistics included roughly a third of the population. Real estate includes both land and buildings. Panel A includes longitude, latitude, and state-fixed effects. Panel B additionally includes geographic and cultural controls as specified in summary statistics. Column 3 reduces the sample to counties in $35 \mathrm{~km}$ distance to the border of the inheritance rule. Independent cities are excluded. Regressions are weighted by population in 1907. Standard errors clustered at the district (Regierungsbezirk) level. ${ }^{*} \mathrm{p}<0.1,{ }^{* *} \mathrm{p}<0.05,{ }^{* * *} \mathrm{p}<0.01$ 
Table A16: Equal Division and Innovation and Entrepreneurship: Appendix Material

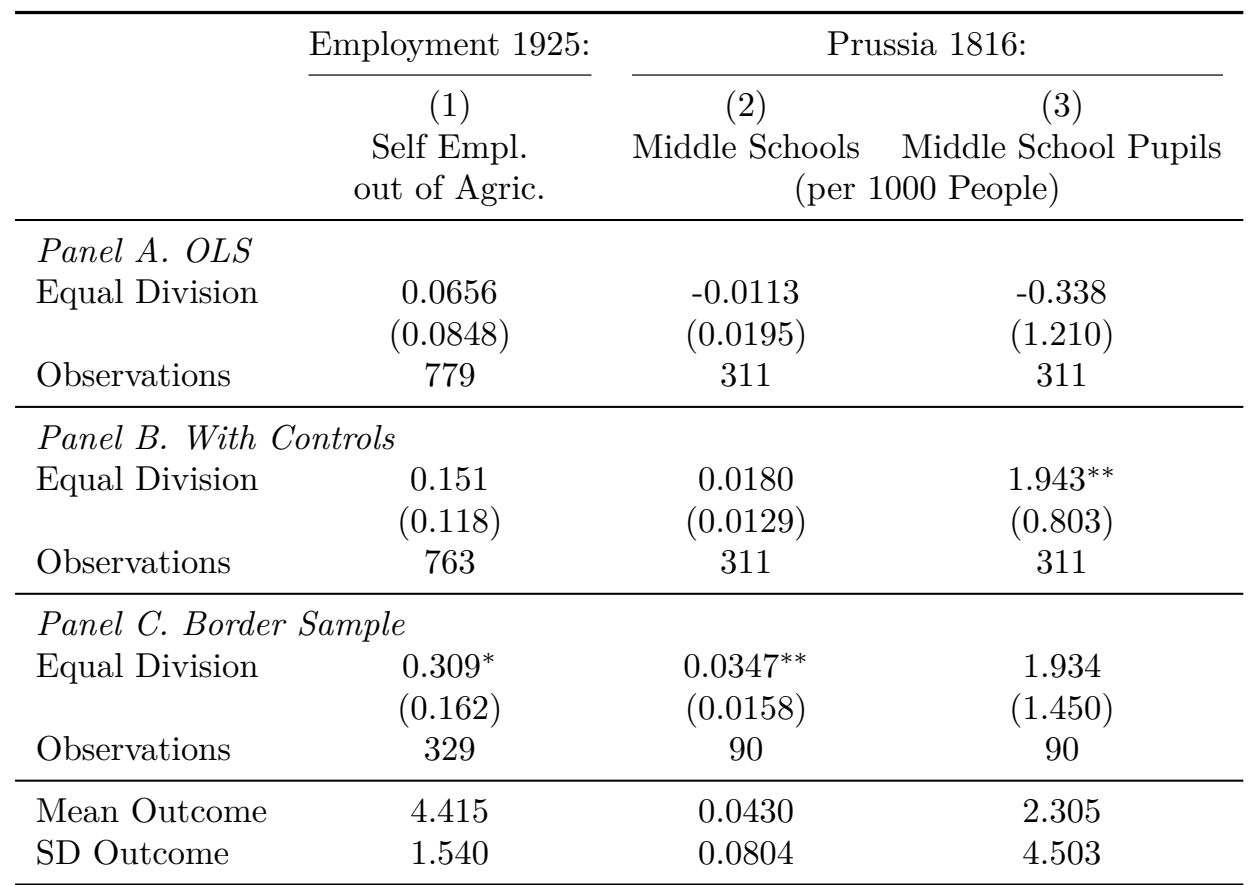

Notes: The table reports the effect of equal division on the outcomes reported in the column headers. The unit of observation is a county. In column 1 the percent of people in self-employment out of agriculture (manufacturing and trade and services) is used as outcome variable for the sample of the whole German Empire in 1925. In column 2 and 3 the sample is reduced to Prussian counties. The number of middle schools (column 2) and the number of pupils in middle schools (column 3) per 1000 people are used as outcome variables. Panel A includes longitude, latitude, and state-fixed effects. Panel B additionally includes geographic and cultural controls as specified in summary statistics. Panel C reduces the sample to counties in $35 \mathrm{~km}$ distance to the border of the inheritance rule. Regressions are weighted by population. Standard errors clustered at the district (Regierungsbezirk) level. ${ }^{*} \mathrm{p}<0.1,{ }^{* *} \mathrm{p}<0.05,{ }^{* * *} \mathrm{p}<0.01$ 